\title{
EFEITOS DE DENSIDADES DE Aeschynomene rudis Benth. E SEU CONTROLE COM O HERBICIDA ETHOXYSULFURON EM DUAS ÉPOCAS DE APLICAÇÃO NA CULTURA DO ARROZ (Oryza sativa L.) IRRIGADO
}

\author{
MARCIO LUIZ ADORYAN
}

Dissertação apresentada à Escola Superior de Agricultura "Luiz de Queiroz", Universidade de São Paulo, para a obtenção do título de Mestre em Agronomia, Área de Concentração: Fitotecnia.

P I R A C I C A B A

Estado de São Paulo - Brasil

Setembro - 2004 


\title{
EFEITOS DE DENSIDADES DE Aeschynomene rudis Benth. E SEU CONTROLE COM O HERBICIDA ETHOXYSULFURON EM DUAS ÉPOCAS DE APLICAÇÃO NA CULTURA DO ARROZ (Oryza sativa L.) IRRIGADO
}

\section{MARCIO LUIZ ADORYAN}

Engenheiro Agrônomo

\section{Orientador: Prof. Dr. GERALDO JOSÉ APARECIDO DARIO}

\author{
Dissertação apresentada à Escola Superior de \\ Agricultura "Luiz de Queiroz", Universidade de \\ São Paulo, para a obtenção do título de Mestre em \\ Agronomia, Área de Concentração: Fitotecnia.
}

P I R A C I C A B A

Estado de São Paulo - Brasil

Setembro - 2004 


\section{Dados Internacionais de Catalogação na Publicação (CIP) DIVISÃO DE BIBLIOTECA E DOCUMENTAÇÃO - ESALQ/USP}

\section{Adoryan, Marcio Luiz}

Efeitos de densidades de Aeschynomene rudis Benth e seu controle com herbicida Ethoxysulfuron em duas épocas de aplicação na cultura do arroz (Oryza sativa L.) irrigado. - - Piracicaba, 2004.

$$
68 \text { p. : il. }
$$

Dissertação (mestrado) - - Escola Superior de Agricultura Luiz de Queiroz, 2004

Bibliografia.

1. Arroz 2. Densidade de planta 3. Época de aplicação 4. Herbicida 5. Plantas daninhas 6 . Várzeas I. Título

CDD 633.18

\section{"Permitida a cópia total ou parcial deste documento, desde que citada a fonte - O autor"}




\section{AGRADECIMENTOS}

Ao Prof. Dr. Geraldo José Aparecido Dario, por sua orientação, sugestões, apoio, respeito e amizade;

Ao Dr. Erwin Hacker pela liberação para a realização dos estudos, auxílio e amizade;

Ao Dr. Klaus Trabold e Dr. Eckhard Rose pelo incentivo, colaboração e amizade;

Ao grande amigo Dr. Gerson Augusto Gelmini por sua amizade, companheirismo, orientação, sugestões e idéias fundamentais para a elaboração deste trabalho;

À pesquisadora Maria do Carmo de Salvo Soares Novo pela orientação e execução das análises estatísticas dos dados e por sua amizade;

À José Licurgo Indiani Neto por sua amizade e permissão para utilizar área e equipamentos na instalação do experimento e ao seu funcionário Rubens pelo apoio;

À Izabel Cristina Gagliardi pelo auxílio e eterna amizade;

À José Ribeiro e demais funcionários da Estação Agrícola Experimental da Bayer CropScience pelo apoio na realização do experimento e por sua amizade;

À John McGregor, Konrad Kemper e Renate Rieper pela ajuda nas traduções e pela amizade;

À Thiago de Oliveira, Wellington Cláudio Justino e demais moradores da república K-labouço pelo auxílio nas pesquisas e principalmente pela amizade e companheirismo. 


\section{SUMÁRIO}

\begin{tabular}{|c|c|}
\hline & ágina \\
\hline RESUMO ......... & vi \\
\hline SUMMARY . & viii \\
\hline ZUSAMMENFASSUNG & $\mathrm{X}$ \\
\hline 1 INTRODUÇÃO ................ & 1 \\
\hline 2 REVISÃO DE LITERATURA ... & 4 \\
\hline 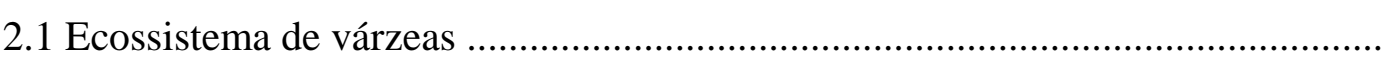 & 4 \\
\hline 2.2 Interações entre espécies vegetais & 5 \\
\hline 2.3 A planta daninha Aeschynomene rudis Benth. ...... & 7 \\
\hline 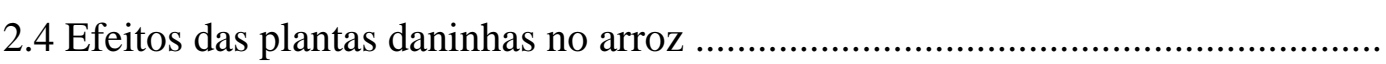 & 8 \\
\hline 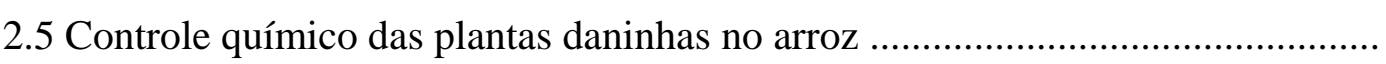 & 15 \\
\hline 3 MATERIAL E MÉTODOS .............. & 19 \\
\hline 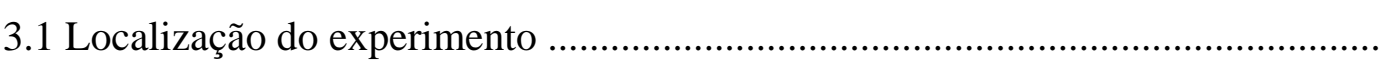 & 19 \\
\hline 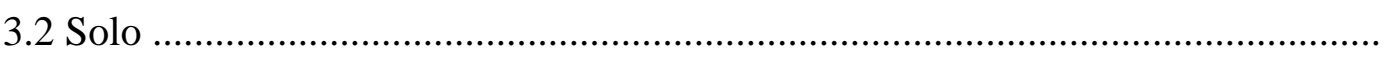 & 19 \\
\hline 3.3 Clima ........ & 19 \\
\hline 3.4 Instalação e condução do experimento ............................................... & 20 \\
\hline 3.5 Delineamento experimental . & 23 \\
\hline 3.6 Tratamentos ............................ & 23 \\
\hline 3.7 Produtos utilizados ....................................... & 24 \\
\hline 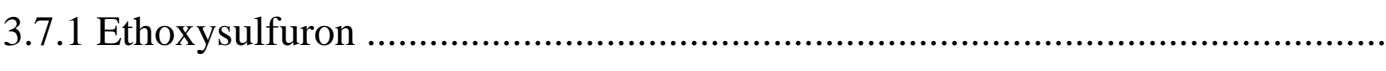 & 24 \\
\hline 3.7.2 Lauril éter sulfato de sódio ... & 25 \\
\hline 3.7.3 Arroz cultivar Epagri 109 .. & 26 \\
\hline 3.7.4 Aeschynomene rudis Benth. & 26 \\
\hline 3.8 Avaliações & 28 \\
\hline
\end{tabular}


3.8.1 Número de plantas por metro ..................................................................... 28

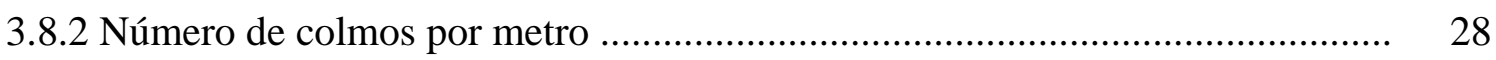

3.8.3 Altura de plantas ........................................................................................ 29

3.8.4 Número de panículas por metro .................................................................... 29

3.8.5 Comprimento de panículas ............................................................................ 29

3.8.6 Número de espiguetas por panícula ............................................................. 29

3.8.7 Número de grãos formados por panícula .......................................................... 29

3.8.8 Rendimeto de grãos ............................................................................... 30

3.8.9 Eficiência do herbicida ............................................................................. 30

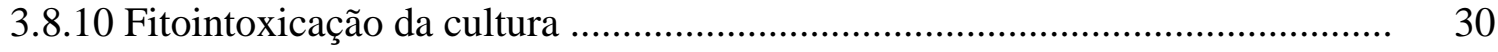

3.8.11 Índice para colheita mecânica .......................................................................... 30

3.8.12 Análises estatísticas ............................................................................. 31

4 RESULTADOS E DISCUSSÃO _.................................................................. 32

4.1 Número de plantas por metro .......................................................................... 32

4.2 Número de colmos por metro ....................................................................... 32

4.3 Altura de plantas ........................................................................................ 33

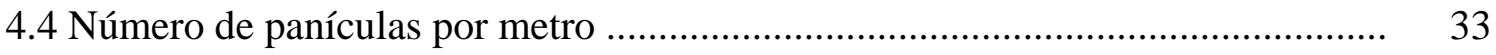

4.5 Comprimento de panículas ............................................................................... 34

4.6 Número de espiguetas por panícula ……………………..................................... 34

4.7 Número de grãos formados por panícula …………………………………….... 35

4.8 Rendimeto de grãos ................................................................................... 36

4.9 Eficiência do herbicida ............................................................................... 36

4.10 Fitointoxicação da cultura ......................................................................... 38

4.11 Índice para colheita mecânica ……………………………………………..... 38

5 CONCLUSÕES ................................................................................... 46

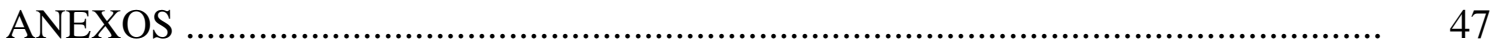

REFERÊNCIAS BIBLIOGRÁFICAS ................................................................... 58 


\title{
EFEITOS DE DENSIDADES DE Aeschynomene rudis Benth. E SEU CONTROLE COM O HERBICIDA ETHOXYSULFURON EM DUAS ÉPOCAS DE APLICAÇÃO NA CULTURA DO ARROZ (Oryza sativa L.) IRRIGADO
}

\author{
Autor: MARCIO LUIZ ADORYAN \\ Orientador: Prof. Dr. GERALDO JOSÉ APARECIDO DARIO
}

\section{RESUMO}

Com o objetivo de avaliar os efeitos de densidades de Aeschynomene rudis Benth. na cultura do arroz irrigado e a eficiência do herbicida ethoxysulfuron aplicado em duas épocas como pós-emergente, foi instalado um experimento no município de Taubaté, região do Vale do Paraíba-SP, no ano agrícola de 2001/2002. O cultivar de arroz Epagri 109 e a planta daninha $A$. rudis foram semeados em 30/10/2001 em solo drenado. Os tratamentos foram constituídos de quatro densidades de $A$. rudis (3, 6, 12 e 24 plantas por metro quadrado) e duas épocas de aplicação do herbicida ethoxysulfuron dentro de cada densidade (estádio de 4 e 6 folhas do $A$. rudis), e cinco parcelas testemunhas com densidades de 0, 3, 6, 12 e 24 plantas de $A$. rudis por metro quadrado sem a aplicação do produto, constituindo 13 tratamentos com 4 repetições, delineados em blocos ao acaso. O herbicida foi aplicado na dose de 80 g.ha ${ }^{-1}$, sendo adicionado à calda o adjuvante lauril éter sulfato de sódio na dose de 0,3 \% base volume, e as pulverizações efetuadas nos dias 27/11/2001 e 04/12/2001. Os parâmetros avaliados foram: número de plantas, colmos e panículas por metro, altura das plantas de arroz, 
comprimento de panículas, número de espiguetas por panícula, número de grãos formados por panículas, rendimento de grãos, eficiência do herbicida no controle de $A$. rudis e fitointoxicação à cultura. Considerando-se os resultados obtidos pode-se concluir que: a) densidades de 3, 6, 12 e 24 plantas de $A$. rudis por metro quadrado, influenciam negativamente de forma linear, o número de colmos e de panículas por metro, o comprimento das panículas, o número de espiguetas e de grãos formados por panícula, o rendimento de grãos e o índice para colheita mecânica e não afetam o número de plantas por metro e a altura das plantas de arroz. b) o herbicida ethoxysulfuron é eficiente no controle de $A$. rudis nos estádios de 4 e de 6 folhas, nas densidades de 3, 6, 12 e 24 plantas por metro quadrado. c) ethoxysulfuron na dose de $80 \mathrm{~g} \mathrm{ha}^{-1}$, quando aplicado em pós-emergência precoce e mediana em densidades de 3, 6, 12 e 24 plantas de A. rudis por metro quadrado é seletivo para o cultivar de arroz Epagri 109, não interferindo nos parâmetros avaliados. 


\title{
EFFECTS OF Aeschynomene rudis Benth DENSITIES AND ITS CONTROL WITH THE HERBICIDE ETHOXYSULFURON AT TWO APPLICATION TIMINGS IN PADDY RICE (Oryza sativa L.)
}

\author{
Author: MÁRCIO LUIZ ADORYAN \\ Advisor: Prof. Dr. GERALDO JOSÉ APARECIDO DARIO
}

\section{SUMMARY}

During the season 2001/2002, an experiment was conducted in Taubaté city, area of the Paraíba-SP valley, to evaluate the effect of Aeschynomene rudis Benth. densities on paddy rice, and the efficacy of the herbicide ethoxysulfuron applied in early and mid post emergence. The rice variety Epagri 109 and A. rudis were planted October 30, 2001 in dry soil. The treatments were four $A$. rudis densities (3, 6, 12 and 24 plants per square meter) and two application timings of the herbicide ethoxysulfuron in each density. The two application timings were at the 4 and 6 leaf stage of $A$. rudis. There were also untreated densities of $0,3,6,12$ and 24 plants of $A$. rudis per square meter without the herbicide application, resulting in 13 treatments with 4 replications delineated in

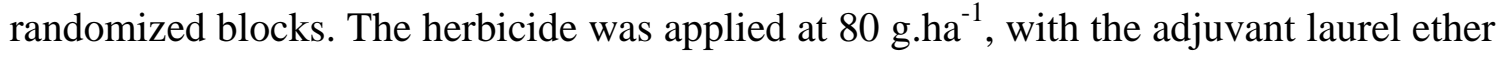
sulfate of sodium at $.3 \% \mathrm{v} / \mathrm{v}$. The applications were made on November 27 and December 4, 2001. The assessed crop parameters were: number of plants, stems and panicles per meter, height of the plants, panicle length, number of spikelets by panicle, number of grains formed by panicles, income of grains, A. rudis control and crop 
damage. We can conclude from the results that $A$. rudis densities of 3, 6, 12 and 24 plants per square meter influence the crop negatively, in a linear way, the number of stems and panicles per meter, the length of the panicles, the number of spikelets and grains formed by panicles, the mechanical harvest index, and rice yield. There were no effects on the number of rice plants per meter or the height of the rice. Also, ethoxysulfuron was effective in controlling $A$. rudis at both the 4 and 6 leaf stage, in densities of 3, 6, 12 and 24 plants per square meter. Ethoxysulfuron at 80 g.ha $^{-1}$, when applied early post or mid post emergence in densities of 3, 6, 12 and 24 plants per square meter was selective to the rice variety Epagri 109, not affecting the assessed parameters. 


\section{EINFLUSS DER BESATZSTÄRKE VON Aeschynomene rudis Benth. UND IHRE KONTROLLE MIT DEM HERBIZID ETHOXYSULFURON AN ZWEI VERSCHIEDENEN BEHANDLUNGSZEITPUNKTEN IN WASSERREIS, Oryza sativa L..}

Autor: MÁRCIO LUIZ ADORYAN Betreuer: Prof. Dr. GERALDO JOSÉ APARECIDO DARIO

\section{ZUSAMMENFASSUNG}

Ziel der Untersuchungen war die Auswertung von Einflüssen der Besatzstärke von Aeschynomene rudis Benth. in Wasserreis bei Anwendung des Herbizides Ethoxysulfuron, an zwei verschiedenen Terminen im Nachauflauf. Der Versuch wurde angelegt in Taubaté, Vale do Paraíba, Bundesstaat São Paulo, im Wirtschaftsjahr 2001/2002, als Sorte wurde „Epagri 109“ verwendet. Sie wurde gemeinsam mit $A$. rudis am 30/10/2001 in drainierten Boden ausgesät. Vier verschiedene Besatzstärken von A.rudis wurden ausgesät: 3, 6, 12 und 24 Pflanzen pro Quadratmeter. Verglichen wurden zwei Applikationszeitpunkte des Herbizides Ethoxysulfuron innerhalb der vier Bestandesdichten: Spritzung bei 4 und 6 Blättern von A. rudis. Als Kontrolle dienten jeweils 5 Parzellen mit 0, 3, 6, 12 und 24 Pflanzen von A. rudis pro Quadratmeter, ohne Anwendung des Produktes. Insgesamt bestand der Versuch aus 13 Behandlungen in 4 Wiederholungen, in 4 Blöcken mit Zufallsverteilung organisiert. Herbiziddosis 80 g.ha ${ }^{-1}$, unter Zumischung von Lauryl Ether Natrium Sulfat mit 0,3\% zur Spritzbrühe. Gespritzt 
wurde am 27/11/2001 und am 04/12/2001. Ausgewertet wurde auf Pflanzenanzahl, Stängel und Rispen der Reispflanzen pro Quadratmeter, Höhe der Reispflanzen, Größe der Rispen, Ährchen pro Rispe, Gesamtanzahl der Körner pro Rispe, Kornertrag, Wirksamkeit des Herbizides zur Kontrolle von A. rudis, sowie die Pflanzenverträtlichkeit an Reis. Folgende Rückschlüsse lassen sich aus dem Versuch ziehen: a) Bestandesdichten von 3, 6, 12 und 24 A. rudis pro Quadratmeter reduzieren linear die Anzahl von Stängeln und Rispen sowie die Größe der Rispen, ebenso die Anzahl der Ährchen, den Index für mechanische Ernte und die Anzahl der Körner pro Rispe. Auch der Ertrag wurde negativ beeinflußt. Nicht reduziert wurde die Anzahl der Reispflanzen pro Fläche sowie deren Wuchshöhe. b) Das Herbizid Ethoxysulfuron ist wirksam bei der Kontrolle von A. rudis im Stadium 4 und 6 Blätter, bei Besatzstärken von 3, 6, 12 und 24 Pflanzen pro Quadratmeter. c) Ethoxysulfuron mit 80 g.ha ${ }^{-1}$, appliziert im frühen oder mittleren Nachauflauf, bei Besatzstärken von 3, 6, 12 und 24 Pflanzen pro Quadratmeter, ist voll verträglich für Wasserreis der Sorte „Epagri 109“, ohne jegliche Auswirkung auf die ausgewerteten Parameter. 


\section{INTRODUÇÃO}

O arroz (Oryza sativa L.) constitui a base da alimentação de aproximadamente 40\% da população mundial, sendo cultivado em mais de uma centena de países (Pereira, 1973; Pinzan, 1997).

A área plantada no mundo em 2001 foi de 150,8 milhões de hectares com uma produção de 590,6 milhões de toneladas, sendo que os principais países produtores são do continente asiático, tendo a Índia e a China como os maiores produtores e consumidores. Neste contexto o Brasil ocupa apenas a $10^{\mathrm{a}}$ colocação com 1,8\% da produção mundial.

A cultura do arroz é desenvolvida em todo o território nacional (Dario, 1987), ocupando na safra 2001/02, área de 3,23 milhões de hectares com produção de 10,66 milhões de toneladas. (FNP, 2003). No Estado de São Paulo a principal região produtora de arroz irrigado situa-se no Vale do Paraíba, com área plantada no ano de 2001 de 10.344 hectares, produção de 44.027 toneladas e rendimento médio de 4.256 kg.ha ${ }^{-1}$, gerando uma renda de 14,5 milhões de reais (IEA, 2003).

O consumo total de arroz no Brasil tem variado pouco nos últimos 10 anos, estando atualmente em 11,7 milhões de toneladas, o que gera a necessidade de importações do produto, principalmente do Uruguai e da Argentina, visando suprir a demanda interna e manter os estoques reguladores (Ferreira, 1999; FNP, 2003).

Atualmente no país o arroz é cultivado basicamente sob dois sistemas: terras altas e irrigado. Tendo em vista os altos riscos, a baixa produtividade e a menor qualidade dos grãos do arroz de terras altas, quando comparados ao irrigado, verifica-se uma tendência de redução da área plantada por este sistema, fomentando a obtenção de 
melhores resultados no cultivo irrigado a fim de atender a demanda interna (Medeiros, 1995).

Assim como ocorre com as demais culturas, o arroz está sujeito a uma série de fatores ambientes que, direta ou indiretamente, influenciam o seu rendimento. Sendo assim, a presença de plantas daninhas, em especial a Aeschynomene rudis Benth., ocupam lugar de destaque face aos efeitos negativos observados no seu desenvolvimento, produção e qualidade do produto final.

Os prejuízos ocasionados pelas plantas daninhas sobre estes parâmetros dependem de vários fatores, como cultivar utilizado, fertilidade do solo, adubação, espaçamento da cultura, espécie infestante e sua densidade. Nas áreas com grande infestação de plantas daninhas, como as que ocorrem no Vale do Paraíba, os danos causados podem chegar à perda total da produção (Cobucci, 1998).

De acordo com Oerke (1994), ensaios em todo o mundo mostram que os prejuízos devido à competição de plantas daninhas na cultura do arroz são muito altos e os índices apontam para 15-20\% de perdas no mundo e cerca de 30\% no Brasil. Este índice é particularmente maior em nosso País devido ao controle pouco adequado das plantas daninhas realizado por muitos de nossos produtores.

Por outro lado, as plantas daninhas não reduzem apenas o rendimento e a qualidade do arroz. Dependendo da espécie e densidade em que ocorrem, elas podem ocasionar graves problemas no processo de colheita, sendo que em áreas infestadas com Aeschynomene rudis Benth., as máquinas são obrigadas a realizar inúmeras paradas para a limpeza das barras e sistema de alimentação devido à obstrução que essas plantas causam, provocando também quebras constantes e redução da durabilidade e da capacidade operacional das colhedoras. Dentro deste contexto, o controle adequado e oportuno das plantas daninhas destaca-se como um dos fatores que mais contribuem para aumentar o rendimento na cultura do arroz. (EMBRAPA, 1992; De Datta \& Herdt, 1983).

Como métodos de controle de plantas daninhas podemos ressaltar: o mecânico, realizado através de implementos manuais ou mecânicos, sendo pouco utilizado devido às peculiaridades inerentes à cultura irrigada; o cultural, que visa oferecer maior 
competitividade da cultura com as plantas daninhas, principalmente nas fases iniciais de seu estabelecimento; o biológico ainda pouco utilizado no Brasil devido sua alta especificidade com relação às plantas daninhas, gerando dificuldades para o produtor, que na grande maioria das vezes, possui em sua propriedade um complexo de plantas invasoras e não apenas uma única espécie; e o controle químico, através da utilização de herbicidas, que tem sido o método mais adotado pelos produtores de arroz devido sua praticidade, eficiência, alto rendimento operacional e economia de mão-de-obra, ainda que esses produtos possam representar 25\% dos gastos com insumos (EMBRAPA, 1992; Lorenzi, 2000a; Oliveira Jr., 2001; Vidal \& Merotto Jr., 2001; FNP, 2003).

Através dos diferentes métodos de controle torna-se possível evitar as perdas de produção devido à competição, melhorar as condições de colheita e evitar o aumento da população de plantas daninhas na área. A associação de métodos de controle deve ser utilizada sempre que possível, porém, é conveniente que a estratégia de controle esteja adaptada às condições locais de infra-estrutura, à disponibilidade de mão-de-obra e implementos, e custos compatíveis com o sistema de produção (Fageria, 1992, Cobucci, 1998).

Atualmente estão registrados no Brasil, 108 princípios ativos herbicidas, representando mais de uma centena de marcas comerciais. Dentro deste universo encontramos o herbicida ethoxysulfuron, devidamente registrado para uso na cultura do arroz, visando o controle de ciperáceas, plantas aquáticas e algumas dicotiledôneas onde se enquadra o Aeschynomene rudis Benth. (MAPA, 2003).

O objetivo deste trabalho foi avaliar o efeito de diferentes densidades de Aeschynomene rudis Benth. (0, 3, 6, 12 e 24 plantas por metro quadrado) na cultura do arroz irrigado, assim como seu controle pós-emergente em duas épocas de aplicação, através do herbicida ethoxysulfuron. 


\section{REVISÃO DE LITERATURA}

\subsection{Ecossistema de várzeas}

O arroz pode ser cultivado em diversos tipos de solos desde que sejam atendidas suas exigências mínimas, em especial, no que tange à disponibilidade hídrica e de nutrientes (Fornasieri Filho \& Fornasieri, 1993). De uma maneira geral os solos apropriados para o cultivo de arroz em várzeas, caracterizam-se por ser de topografia plana, hidromórficos e que permanecem saturados em períodos de maior precipitação (EPAGRI, 1997; Guimarães \& Santana, 1999), e por ser um ambiente diferenciado, estas áreas apresentam flora característica, com o predomínio de espécies mais adaptadas às condições de saturação do solo.

Dentro desse ecossistema, o arroz pode ser cultivado em várzeas sistematizadas com controle da lâmina de água, denominado sistema irrigado ou não sistematizadas, com irrigação através da água das chuvas ou elevação do lençol freático, denominado sistema de várzea úmida.

O sistema de várzea úmida caracteriza-se pelo baixo nível de insumos, sendo em geral, efetuado em pequenas propriedades com mão-de-obra familiar, utilizando máquinas de pequeno porte e na ausência de sistemas de controle e eliminação de água. O plantio é feito através de semeadura direta ou transplante de mudas, sendo que a época é determinada pela capacidade de se manejar o solo o que coincide com o início da estação chuvosa.

Segundo Eberhardt et al. (1997), a germinação e emergência de Aeschynomene spp. é maior quando o solo encontra-se na capacidade de campo do que na presença de lâmina d’água. Sendo assim, o sistema de várzea úmida, por permanecer longos períodos 
com o solo na capacidade de campo, favorece muito o aparecimento e disseminação dessa espécie de planta daninha.

O sistema irrigado por inundação em várzea sistematizada é responsável pela maior parte da produção brasileira, sendo amplamente difundido no sul do País e também na região do Vale do Paraíba em São Paulo.

Os diferentes sistemas de produção adotados pelos produtores, são responsáveis pela maior ou menor disseminação das plantas daninhas (Smith Jr., 1983). Os métodos de preparo do solo para o arroz inundado, dependem do nível de sistematização do terreno. Atualmente predominam os sistemas: convencional, cultivo mínimo, plantio direto, sementes pré-germinadas e bem menos expressivo o transplante de mudas (EPAGRI, 1997; Guimarães \& Santana, 1999).

O sistema convencional, preferencialmente adotado pelos agricultores, tem contribuído para a degradação dos solos assim como para a disseminação de plantas daninhas. O cultivo mínimo, o plantio direto e o sistema pré-germinado, contribuem sobremaneira para o controle das plantas daninhas, permitindo também uma maior integração lavoura pecuária (Pinzan, 1997; Mello, 1995).

\subsection{Interações entre espécies vegetais}

Populações de duas espécies vegetais podem interagir entre si de três formas básicas: positivas, negativas e neutras, e as combinações destas interações, quando duas ou mais plantas estão em convivência, são classificadas como: neutralismo, competição, amensalismo, parasitismo, predação, comensalismo, protocooperação e mutualismo (Odum, 1988).

As interferências podem ser classificadas em simétricas ou assimétricas e diretas

ou indiretas. Quando causada por apenas um dos indivíduos, é chamada de assimétrica, e se os dois organismos interferem mutuamente entre si é denominada de simétrica. É considerada interferência direta quando ocorrem efeitos diretos no corpo físico de um ou todos os organismos em convivência, e indireta quando ocorre no habitat compartilhado pelos organismos (Odum, 1988). 
Diversos experimentos em laboratório e em condições de campo servem de base para esta teoria, que sintetizou o princípio da exclusão competitiva e da competição e coexistência. O primeiro afirma que duas espécies não podem coexistir indefinidamente quando possuem a mesma exigência de recursos. Entretanto, a competição provoca muitas adaptações seletivas que facilitam a coexistência de uma diversidade de organismos numa dada área ou comunidade (Christoffoleti, 2002), sendo que, de uma maneira geral, a competição pode ser entendida como uma interação onde dois organismos procuram o mesmo recurso para sua sobrevivência, ou quando existe uma inibição de cada espécie pela outra (Odum 1988; Christoffoleti, 2002).

A existência, crescimento e sobrevivência de uma população dependem da disponibilidade natural de um recurso e de seu consumo pela própria população e por todas as demais que vivem no mesmo ambiente. Logo, o crescimento destas populações responde à Lei do Mínimo de Liebig, que indica que as populações crescem até que o suprimento de algum recurso não mais satisfaça suas necessidades, sendo este recurso denominado limitante (Odum 1975;1988; Christoffoleti, 2002).

A equação logística de Lotka \& Gause, descrita por Ricklefs (1997), iniciou a formulação de teorias sobre competição, expressando que a taxa de aumento de uma população i (dNi/dt) é função do número de indivíduos da população $(\mathrm{N})$, da capacidade de suporte do ambiente (K) e da taxa exponencial de crescimento da população (r).

A competição intraespecífica está presente no termo $(\mathrm{K}-\mathrm{N}) / \mathrm{K}$ e atinge-se um equilíbrio estável quando $\mathrm{N}=\mathrm{K}$, isto é, o tamanho da população alcança a capacidade de suporte do meio. A teoria da competição e coexistência é descrita quando se incorpora a presença de uma segunda espécie (j) no modelo: Dni / dt = riNi (Ki - Ni - aijNj / Ki), onde, $\mathrm{Nj}$ é o número de indivíduos da segunda espécie e aij é o coeficiente de competição, isto é, o efeito da espécie j no crescimento exponencial da população da espécie (i) ou o grau da espécie j sobre o uso de recursos da espécie i.

Segundo Ricklefs (1997), é possível diferenciar dois tipos de mecanismos: (1) de esgotamento (nos quais os indivíduos privam os demais do uso ou benefícios de um recurso); (2) ou de interferência (onde os indivíduos diretamente afetam os outros através de meios físicos ou químicos). Estes mecanismos podem ser subdivididos em 
seis categorias sendo que sua ocorrência depende das características dos organismos e do ambiente em que eles vivem: (a) consumista - baseado no consumo de recursos renováveis; (b) antecipatória - baseada na ocupação de um espaço aberto; (c) supercrescimento - quando um indivíduo ocorre ou cresce acima do outro, limitando sua aquisição de recursos; (d) química - pela produção de toxinas; (e) territorial - pela defesa de espaço; (f) enfrentamento - interação sobre um recurso que pode resultar em dano físico, perda de tempo ou energia.

A coexistência e competição entre plantas daninhas e culturas ocorre porque há recursos para ambas, isto é, há nicho ecológico para as duas espécies. Segundo Gliessman (2001), o nicho ecológico de um organismo é definido como seu lugar e função no ambiente, compreendendo seu papel trófico, sua posição física no ambiente, seus limites e tolerância às condições ambientes e seu relacionamento com os outros organismos. O conceito de nicho ecológico torna-se fundamental para a compreensão do impacto potencial de uma população no ambiente e sobre os demais organismos ali presentes. Os organismos com nichos estreitos são chamados especialistas e os de nichos amplos (com alta adaptação e plasticidade) são generalistas. O nicho de uma espécie define a quantidade e a qualidade dos recursos necessários à sua sobrevivência.

Sendo assim, uma cultura agrícola pode sofrer mais impactos com a presença de uma espécie de planta daninha especializada, com nicho semelhante à da própria cultura, do que com a interferência de uma comunidade mista de plantas daninhas com diferentes nichos e quanto mais similares os nichos, mesma fenologia, arquitetura e demanda por água, luz e nutrientes, mais intensa será a competição e a tendência de exclusão competitiva de uma das populações, como o que ocorre com a cultura do arroz (Oryza sativa L.) e o Aeschynomene rudis Benth.

\subsection{A planta daninha Aeschynomene rudis Benth.}

O grupo botânico das fabaceaes no Brasil tem, entre seus diversos táxones genéricos, uma bem expressiva representatividade em Aeschynomene e de um total aproximado de 160 espécies descritas no mundo, 84 espécies distribuem-se pelo 
continente americano, com absoluta predominância na região neotrópica , sendo que no Brasil ocorrem 52 espécies (Fernandes, 1996).

As espécies de Aeschynomene apresentam pouca importância econômica positiva, contribuindo apenas para a fixação de nitrogênio ao solo, sendo este um fato comum entre as fabaceaes, graças ao desenvolvimento de nódulos nas raízes, associados simbioticamente às bactérias nitrificantes, e embora algumas espécies formem em geral, populações densas e luxuriantes, não apresentam valor forrageiro, devido à sua reduzida biomassa. Também não há referências sobre sua utilização como adubo verde ou outras aplicações. Ovinos, caprinos e eventualmente bovinos, se alimentam de determinadas espécies por alguma palatabilidade ou por extrema necessidade alimentar (Fernandes, 1996). Foi verificado recentemente que sementes de Aeschynomene spp., presentes nos resíduos de beneficiamento de arroz, têm causado intoxicações quando consumidas como ração pelos animais (Kissmann \& Groth, 1999).

No ambiente agrícola as plantas de Aeschynomene spp., são consideradas invasoras, principalmente nas regiões produtoras de arroz irrigado e por ser uma planta vigorosa, mesmo quando presente em baixas infestações, é muito prejudicial à cultura do arroz, pois além de competir pelos fatores de produção, dificulta muito a colheita mecânica. As sementes dessa espécie, por ser de coloração escura, quando em mistura com o arroz, depreciam a qualidade e conseqüentemente, o valor comercial do produto final (Andrade, 1986) obrigando as empresas beneficiadoras à instalar custosos equipamentos com selecionadores eletrônicos, para eliminar as sementes de Aeschynomene spp. dos lotes de sementes ou do arroz beneficiado, onerando o processo (Kissmann \& Groth, 1999).

As folhas do Aeschynomene rudis Benth. são do tipo sensitiva podendo influir na eficiência dos herbicidas de pós-emergência, pois se aplicados no momento em que as folhas estão fechadas, a superfície de exposição à calda diminui muito e a absorção será prejudicada (Kissmann \& Groth, 1999). 


\subsection{Efeitos das plantas daninhas no arroz}

Através da competição direta por água, luz e nutrientes, principalmente, e de ações indiretas como hospedeira de pragas e doenças e, muitas vezes, de seus efeitos alelopáticos, as plantas daninhas ocasionam perdas na produção e na qualidade do arroz, além de prejudicar sobremaneira a operação de colheita, podendo até inviabilizá-la Os efeitos negativos sobre ao rendimento são bastante diversos e dependem de vários fatores, como cultivar utilizado, fertilidade do solo, adubação empregada, aspectos fitotécnicos (espaçamento e densidade de plantio), período de convivência com a cultura e principalmente da densidade e espécie daninha presente (Gelmini, 1988;Victória Filho, 2001).

Um grande número autores tem estudado o período crítico de competição, quando a cultura do arroz deve ser mantida livre da presença das plantas daninhas para a obtenção de altos rendimentos. De maneira geral, os valores encontrados situam-se entre 15 e 45 dias do ciclo (Dario, 1992; Cobucci \& Noldin, 1999).

São estimadas perdas de $10 \%$ em rendimento e qualidade, nas diversas culturas em todo o mundo devido à presença de plantas daninhas. Em adição a essas perdas, somam-se as despesas causadas pelo custo dos herbicidas e das práticas culturais e mecânicas para manter a cultura isenta de competição (Smith Jr., 1983).

O Brasil ocupa lugar de destaque na América Latina na produção de arroz, porém, o rendimento da cultura é muito baixo quando comparado a outros países e são estimadas em $30 \%$ as perdas de rendimento devido à presença de plantas daninhas, entretanto este nível pode variar bastante em função das espécies infestantes e suas densidades populacionais (Oerke et al, 1994).

As plantas daninhas geralmente apresentam maior velocidade de emergência do que o arroz, principalmente por estarem mais próximas à superfície do solo e por estarem pré-embebidas quando da semeadura do arroz, tendo a possibilidade de iniciar o processo de hidrólise dos compostos de reserva antes que as sementes do arroz. Sendo assim, o desenvolvimento de cultivares com maior velocidade de emergência, crescimento radicular acentuado, assim como uma rápida formação de fitomassa da 
parte aérea, auxilia sobremaneira a diminuição dos efeitos da competição inicial (Balbinot Jr., 2001).

São inúmeras as espécies de plantas daninhas que competem com a cultura do arroz (Aranha \& Pio, 1981; Noldin, 2001) variando de acordo com o local, condições do solo e fatores climáticos. Dentro dessa flora característica podemos destacar como espécies mais importantes ocorrentes no Brasil, em lavouras irrigadas: Aeschynomene denticulata Rudd, Aeschynomene rudis Benth., Cyperus difformisL., Cyperus esculentus L., Cyperus ferax Rich., Cyperus iria L., Echinochloa colonum (L.) Link, Echinochloa crusgalli var crusgalli (L.) P. Beauv., Echinochloa crusgalli var cruspavonis (Kunth) Schult., Fimbristylis miliacea (L.) Vahl, Heteranthera reniformis Ruiz \& Pav., Ipomoea sp Ischaemum rugosum Salisb., Leersia hexandra Sw., Ludwigia longifolia (DC.) Hara, Ludwigia octovalvis (Jacq.) Raven, Luziola peruviana Juss., Oryza sativa L. e Sagittaria montevidensis Vham. \& Schltdl.

De acordo com Fageria (1992), o potencial de rendimento de uma cultura é uma estimativa do limite superior dos incrementos que podem ser obtidos a partir de uma planta cultivada. A quantidade e a qualidade são fatores importantes na produção, sendo que, um está relacionado com o outro. É reconhecido que o rendimento de uma cultura pode ser aumentado através do melhoramento genético e gerenciamento correto da lavoura, porém a qualidade pode ficar comprometida se não for devidamente considerada. A qualidade pode ser determinada por uma série de propriedades físicoquímicas como cor, textura, aroma, conteúdo protéico, qualidade desta proteína em termos da composição de aminoácidos, digestibilidade e presença de organismos estranhos como sementes de plantas daninhas.

Segundo Cobucci (1998), em áreas altamente infestadas, os danos causados pelas plantas daninhas podem chegar até à perda total da produção. Tozani \& Silva (1995), estudando a interferência de Cyperus rotundus L. em arroz de sequeiro conduzido em diferentes densidades e espaçamentos, verificaram redução de $75 \%$ na produção de grãos de arroz e 69\% no número de panículas devido à competição com C. rotundus L.

Nesse sentido, Calegaro \& Bauer (1983) estudando o comportamento de alguns herbicidas no controle de plantas daninhas na cultura do arroz, mostraram uma variação 
de 16 e 77\% de redução no rendimento da cultura devido a competição ocasionada por 5 e 80 plantas por metro quadrado de Echinochloa spp., respectivamente.

Áreas de arroz irrigado com a presença de 11 plantas por metro quadrado de Aeschynomene virginica (L.) B.S.P., durante todo o ciclo da cultura, mostraram um decréscimo de 19\% no rendimento de grãos segundo estudo realizado por Smith Jr. (1983) em várzeas irrigadas da região sul dos Estados Unidos.

Xavier \& Pinto (1983), observaram perdas de 17\% na produção do arroz cultivar Bluebelle em experimento para o controle de Aeschynomene hispida Willd. e Echinochloa spp. com populações de 60 e 80 plantas por metro quadrado, respectivamente.

Ainda, os mesmos autores em 1985, estudando o comportamento de herbicidas no controle de Aeschynomene rudis Benth. e Aeschynomene hispida Willd., no município de Capão do Leão, RS, relataram perdas de 75\% na produção de grãos para a mesmo cultivar Bluebelle, em área com infestação de 62 e 9 plantas por metro quadrado destas invasoras, respectivamente.

Do mesmo modo, Abud (1985), avaliando a eficiência de diferentes herbicidas na cultura do arroz irrigado cultivar BR-IRGA409, observou perdas de $44 \%$ no rendimento de grãos devido à presença de populações de Echinochloa crusgalli (L.) P. Beauv. (86 plantas. $\left.\mathrm{m}^{-2}\right)$, Cyperus difformis L. (20 plantas. $\left.\mathrm{m}^{-2}\right)$ e Alternanthera philoxeroides (20 plantas. $\left.\mathrm{m}^{-2}\right)$.

Andrade (1986), em experimento para o controle integrado de Aeschynomene spp. através do uso de herbicidas e do Colletotrichum glorioisporioides, pode observar redução de 63 \% no rendimento da cultura do arroz irrigado cultivar BR-IRGA 410, devido a uma infestação de 150 plantas por metro quadrado.

No ano agrícola de 1987, o mesmo autor, estudando a viabilidade de diferentes herbicidas aplicados em pós-emergência tardia das plantas daninhas, constatou perdas de 100\% no rendimento da cultura em área com 200 plantas de Aeschynomene rudis Benth. por metro quadrado. 
Andrade \& Silva (1989), verificaram em ensaio de campo para o controle simultâneo de Aeschynomene spp. e Echinochloa spp.na cultura do arroz irrigado, perdas de 89 \% na colheita devido à competição ocasionada por estas infestantes.

Noldin (1989), estudando o controle químico de plantas daninhas em arroz cultivar Empasc 105 cultivada no sistema pré-germinado, constatou redução de 23\% no rendimento de grãos devido à presença de Sagitaria montevidensis Cham. \& Schltdl e Echinochloa spp., em populações de 33 e 114 plantas por metro quadrado, respectivamente.

Kwon et al. (1991), estudando a interferência de densidades de arroz vermelho na cultura do arroz, verificaram que o aumento de uma planta de arroz vermelho (Oryza sativa L.) por metro quadrado correspondeu a uma perda de 178 e $272 \mathrm{~kg}^{\circ} \mathrm{ha}^{-1}$ nos cultivares Newbonnet e Lemont, respectivamente. Mcgregor et al. (1988), constataram que o rendimento do arroz diminuiu em $18 \mathrm{~kg} . \mathrm{ha}^{-1}$ para cada aumento de uma planta de Brachiaria platyphylla por metro quadrado.

Stauber et al. (1991), estudando a interferência de densidades de Echinochloa crusgalli, assim como sua distribuição espacial na cultura do arroz, verificaram perdas de 75\% no rendimento de grãos devido à presença de 80 plantas desta invasora, por metro quadrado nos cultivares Lemont e Newbonnet.

Abud (1991a, b, c), analisando o comportamento de diferentes herbicidas pósemergentes na cultura do arroz irrigado cultivar BR-IRGA 412, verificou uma diminuição da produção de grãos de 45\%, ocasionada pela competição de populações de 4 plantas de Aeschynomene rudis Benth. e 36 plantas de Echinochloa crusgalli (L.) P. Beauv. por metro quadrado, com a cultura. Em um segundo experimento naquele ano, o mesmo autor relatou um decréscimo de $43 \%$ no rendimento da cultura, devido à presença de 4 plantas de Aeschynomene rudis Benth. e 40 plantas de Echinochloa crusgalli (L.) P. Beauv. por metro quadrado. Ainda o referido autor, trabalhando com uma população de 12 plantas de Aeschynomene rudis Benth. e 70 plantas de Echinochloa crusgalli (L.) P. Beauv. por metro quadrado, constatou uma redução na colheita de 52\% devido à competição ocasionada por estas invasoras. 
Ainda de acordo com Abud (1993), em trabalho realizado no município de Santa Maria - RS visando verificar os efeitos de diferentes doses do herbicida bensulfuronmetil comparado ao bentazon e ao 2,4D, área com infestação de 12 plantas de Aeschynomene rudis Benth. e 52 plantas de Cyperus iria L., por metro quadrado, apresentou perda de 23\% no rendimento da cultura do arroz irrigado cultivar BR-IRGA 409.

Constantin et al. (1995), estudando a eficiência do herbicida oxadiazon no controle de plantas daninhas em arroz pré-germinado, constatou redução de $56 \%$ na produção do cultivar IAC4440, em áreas infestadas com 250, 16 e 14 plantas por metro quadrado de Fimbristylis diphylla, Polygonum persicaria L. e Ischaemum rugosum Salisb., respectivamente.

Andres \& Menezes (1997), visando o controle de Echinochloa crusgalli (L.) P. Beauv.e Aeschynomene denticulata Rudd. em populações de 247 e 2 plantas por metro quadrado respectivamente, através do uso do herbicida bispyribac-sodium, constataram uma redução de 62\% no rendimento do arroz irrigado cultivar IRGA 417 devido à competição ocasionada pelas plantas daninhas.

Bizzi \& Andres (2001), em trabalho para o controle químico de plantas daninhas no sistema convencional de cultivo do arroz irrigado, relataram perdas de $28 \%$ no rendimento da cultura, cultivar IRGA 417, devido à presença de 12 plantas por metro quadrado de Aeschynomene denticulata Rudd. e 560 plantas de Cyperus iria L..

Nessa mesma linha, Schwanke et al. (2001), verificando a eficiência do herbicida cyhalofop isoladamente ou em mistura com herbicidas pré-emergentes em arroz irrigado, relataram perdas de 64\% na produção do arroz cultivar BRS 6 na presença de 95 e 5 plantas por metro quadrado de Echinochloa crusgalli (L.) P. Beauv. e Aeschynomene denticulata Rudd., respectivamente.

Menezes et al. (2001), avaliaram o rendimento de grãos de arroz irrigado e seus componentes (peso de 100 grãos, número de grãos por panícula e número de panículas por área), porcentagem de colmos inférteis e estatura da planta quando na presença de algumas densidades de Aeschynomene denticulata Rudd., assim como a produção de sementes pela invasora em função das diferentes populações. Os tratamentos 
constituíram de nove populações de Aeschynomene denticulata Rudd.; 0, 2, 4, 9, 18, 28, 38, 50 e 75 plantas por metro quadrado.

Segundo os autores, o rendimento de grãos da cultura, diminuiu à medida que a população da planta daninha aumentou, principalmente nas populações de 2 a 18 plantas por metro quadrado, sendo que, a partir desta última população, o decréscimo no rendimento foi menos acentuado. O rendimento de grãos de arroz nas parcelas sem infestação foi 13,5\% e 34,7\% maior do que em relação às parcelas com 2 e 75 plantas de Aeschynomene denticulata Rudd. por metro quadrado, respectivamente. O número de panículas de arroz por área, foi o componente de rendimento de grãos mais afetado pelo aumento da população de angiquinho, já que, para os demais, não se observaram diferenças significativas. Para os autores, o controle desta invasora torna-se economicamente viável a partir de 2 plantas por metro quadrado devido aos efeitos negativos na produção. Além das perdas, o controle justifica-se em função do potencial de produção de sementes da planta daninha, interferindo negativamente na qualidade comercial do produto final e no aumento do banco de sementes para as próximas safras.

Menezes et al. concluíram que o Aeschynomene denticulata Rudd. apresenta uma grande capacidade de competir com a cultura do arroz irrigado, reduzindo o rendimento de grãos e afetando a qualidade do produto final, sendo recomendado o seu controle sempre que esta espécie estiver presente na lavoura.

O conhecimento da relação entre espécie, número de plantas por metro quadrado, distribuição, período de convivência, perdas de rendimento e eficiência de colheita é de grande importância para determinar a época e o método de controle mais adequado. Para a amostragem das espécies, sua distribuição e densidade, devem ser levados em consideração, o histórico, tamanho da área, eficiência e confiabilidade do método de análise (Garret, 1995; Krueger et al., 2000, Ngouajio et al., 2001).

Wiles et al. (1992), estudaram a distribuição espacial das plantas daninhas nos campos cultivados a fim de determinar o melhor tratamento pós-emergente e verificaram que a distribuição espacial das plantas é ponto chave na tomada de decisão por ter relação direta com as perdas de produção. 
Porém, Van Gessel (1995), trabalhando com densidades e distribuição de plantas daninhas em milho, afirmou que a distribuição espacial não mostrou impacto no rendimento, mas sim a densidade das plantas daninhas foi o fator crucial.

Não só a densidade das plantas daninhas pode exercer influências nas culturas, mas a situação inversa também ocorre. Ghosheh et al. (1996), verificaram que com o aumento da densidade do milho ocorria um decréscimo acentuado no peso fresco de Sorghum halepense.

Swinton et al. (1994), desenvolveram modelos capazes de relacionar a densidade e espécies de plantas daninhas com perdas de produção para as culturas de milho e soja, permitindo assim determinar a escolha ou não de um determinado método de controle.

Nessa mesma linha, VanDevender et al. (1997), criaram um modelo envolvendo o decréscimo na produção de grãos de arroz em função da densidade de plantas daninhas e a duração da interferência, porém para se obter um modelo exato, outros parâmetros devem ser considerados como, o cultivar de arroz, distribuição e espécies infestantes.

Os modelos matemáticos são uma ferramenta a mais no manejo de plantas daninhas porém muitas vezes empírica, que deve ter sua efetividade comprovada e mesmo ajustada para as mais diversas situações que podem ocorrer no campo (Shaw, et al., 1998, Ngouajio et al., 2001).

\subsection{Controle químico de plantas daninhas no arroz}

O controle de plantas daninhas consiste na adoção de certas práticas que resultam na diminuição da população infestante, mas não necessariamente na sua completa eliminação (Lorenzi, 2000a).

Nesse sentido, o controle químico das plantas daninhas através do uso de herbicidas, tem sido um dos métodos mais utilizados na cultura do arroz, principalmente no sistema irrigado, devido à maior praticidade, à grande eficiência e ao alto rendimento operacional que se consegue nas aplicações. O uso de herbicidas permite ainda o controle em épocas de maior pluviosidade, assim como em áreas encharcadas, onde 
outros métodos, como o mecânico ou o manual, seriam ineficientes ou impossíveis de serem realizados (Cobucci \& Noldin, 1999; Carvalho et al., 2000).

O controle químico, parte do princípio que existem produtos capazes de matar ou exercer forte inibição num determinado grupo de plantas sem injuriar outras (Lorenzi, 2000a). Possibilita ainda, o controle das plantas daninhas antes ou depois de emergidas, dentro e fora da linha de plantio, efeitos mais prolongados com menores possibilidades de reinfestação, redução do número de tratos culturais, liberando a mão-de-obra e permitindo sua melhor distribuição dentro da propriedade (Gelmini, 1988).

Por outro lado, a obtenção de resultados positivos no controle químico, encontrase na dependência de uma série de fatores relacionados com a comunidade infestante, tipo de solo, tecnologia e época de aplicação, distribuição de chuvas e comportamento da cultura em relação às características dos herbicidas, assumindo grande importância os diversos aspectos relativos à seletividade que tais produtos possam apresentar (Gelmini, 1988; Santos et al., 2000).

A flexibilidade do herbicida com relação ao estádio de aplicação é uma característica desejável, principalmente para grandes áreas, adequando a demanda de trabalho ao maquinário, implementos e mão-de-obra disponíveis (Oliveira Jr., 2001).

A viabilidade econômica da aplicação de herbicidas depende do nível tecnológico do produtor e da infestação das plantas daninhas. Fischer \& Ramirez (1993), em trabalho desenvolvido no CIAT, Colombia, analisaram economicamente a aplicação de herbicidas no controle de Echinochloa spp., e concluíram que, para produtores que obtém rendimentos na ordem de $5600 \mathrm{~kg} \cdot \mathrm{ha}^{-1}$, o emprego de herbicidas pós-emergentes só se justifica em densidades superiores a 20 plantas daninhas por metro quadrado, ao passo que para rendimentos de $3500 \mathrm{~kg} \cdot \mathrm{ha}^{-1}$, a aplicação somente é econômica nas densidades acima de 30 plantas por metro quadrado.

Dentre os herbicidas utilizados na cultura do arroz, destacam-se os do grupo químico das sulfoniluréias, que inibem a ação da enzima acetolactate synthase (ALS), também chamada acetohydroxyacid synthase (AHAS), que cataliza a primeira reação na produção dos aminoácidos de cadeia ramificada valina, leucina e isoleucina. 
Os inibidores da acetolactate synthase compõem uma das classes mais numerosas de herbicidas registrados atualmente no Brasil, somando um mínimo de 19 ingredientes ativos, dos quais 5 são utilizados na cultura do arroz. Forma um grupo importante para o controle de plantas daninhas devido à utilização de doses baixas, com boa seletividade para a maioria das culturas importantes, grande espectro de ação e perfil toxicológico favorável (Vidal \& Meroto, 2000). Porém o uso constante destes produtos nas áreas produtoras de arroz irrigado, principalmente no sul do Brasil, tem acarretado no aparecimento de biótipos resistentes, como no caso de Cyperrus difformis L., Sagittaria montevidensis Cham. \& Schltdl e Fimbristylis miliacea (L.) Vahl, não sendo relatado até o momento, nenhum caso de resistência para Aeschynomene rudis Benth. (Noldin et al., 2002; Heap, 2003).

A estrutura típica de uma sulfoniluréia é caracterizada pela presença de uma ponte sulfoniluréia conectando dois anéis. O anel preso ao átomo de enxofre tem um ortho substituto, que pode ser um anel benzeno, pyridina ou não aromático (Stidham, 1991).

O mecanismo mais comum de tolerância aos herbicidas pertencentes ao grupo das sulfoniluréias é a metabolização da molécula ou em alguns casos, a velocidade de absorção e translocação dos herbicidas. A seletividade a algumas espécies de plantas está fundamentada na habilidade em metabolizar o herbicida a compostos não fitotóxicos, com grande velocidade, impedindo que níveis letais do herbicida cheguem na enzima ALS (Saari et al., 1994).

Entre as reações metabólicas mais comuns envolvidas na seletividade deste grupo de herbicidas, estão a hidroxilação do anel aromático, hidroxilação alifática, desalquilação, deesterificação e conjugação, sendo que algumas destas reações podem ocorrer simultaneamente ou se complementar para que o processo de metabolização se concretize (Cole et al., 1994; Saari et al., 1994).

Kocher (1995), trabalhando com ethoxysulfuron marcado, a fim de determinar o mecanismo de seletividade, concluiu que plantas de arroz e Cyperus serotinus absorviam a mesma quantidade de produto, porém no arroz a translocação foi muito menor. A taxa 
de degradação de ethoxysulfuron em produtos hidrofílicos foi marcantemente mais rápida no arroz do que em Cyperus serotinus.

O herbicida ethoxysulfuron, pertencente ao grupo das sulfoniluréias, tem sido largamente utilizado para o controle de dicotiledôneas e ciperáceas na cultura do arroz.

Segundo Dario et al. (1995), o herbicida ethoxysulfuron nas doses de 80 e 100 g/ha, controla com grande eficiência Aeschynomene rudis Benth., no estádio de 2 a 4 folhas, em arroz irrigado, cultivar IAC 101, não verificando qualquer sintoma de injúria à cultura.

Testando doses de 45, 60, 75, 90 e 120 g/ha do herbicida ethoxysulfuron, Dario et al. (1997), obtiveram excelentes resultados no controle pós-emergente de Aeschynomene rudis Benth. e Cyperus iria L. em arroz irrigado cultivar IAC 4440, sem observar sintomas de fitointoxicação mesmo nas doses maiores de 90 e 120 g/ha, mostrando assim, a completa seletividade do produto à cultura.

Gelmini et al. (1997), em ensaio para o controle de plantas daninhas em arroz irrigado no Vale do Paraíba, SP, concluíram que o herbicida ethoxysulfuron nas doses de 80 e 100 g/ha proporcionou excelente controle de Aeschynomene rudis Benth.e Cyperus irira L. no estádio de 4 a 6 folhas, sem provocar injúrias as plantas de arroz cultivar IAC 101.

Adoryan et al. (2000), em trabalho realizado na região do Vale do Paraíba, SP, concluíram que o herbicida ethoxysulfuron, aplicado no estádio de 2 a 4 folhas das plantas daninhas, é muito eficiente no controle de Aeschynomene rudis Benth. nas doses de 48, 60 e 80 g/ha, sendo também totalmente seletivo ao arroz cultivar Epagri 109.

Estudando a eficiência do herbicida ethoxysulfuron, no controle de plantas daninhas na cultura do arroz irrigado, Dario \& Adoryan (2000), concluíram que o produto nas doses de 45, 60 e 80 g/ha , quando aplicado em pós-emergência das plantas daninhas, foi eficiente no controle de Aeschynomene rudis Benth. sem apresentar injúrias ao arroz cultivar IAC 101. 


\section{MATERIAL E MÉTODOS}

\subsection{Localização do experimento}

O experimento foi conduzido na fazenda Vista Alegre, localizada no município de Taubaté, São Paulo, com coordenadas geográficas $23^{\circ} 18^{\prime}$ de latitude sul, $45^{\circ} 33^{\prime}$ de longitude oeste e altitude de $560 \mathrm{~m}$.

\subsection{Solo}

Gleissolo melânico característico de várzea, com baixa capacidade de drenagem e textura franco-arenosa.

\subsection{Clima}

A região caracteriza-se pelo clima tropical de altitude, com temperatura média anual de $21,6^{\circ} \mathrm{C}$ e precipitação de $1310 \mathrm{~mm}$. Na Tabela 1 estão expressos os dados climáticos coletados durante a execução do experimento. 
Tabela 1. Dados climáticos durante o experimento. Taubaté - SP, 2001/2002

\begin{tabular}{|c|c|c|c|c|}
\hline \multirow[t]{2}{*}{ Semana } & \multirow{2}{*}{$\begin{array}{c}\text { Precipitação } \\
\text { mm }\end{array}$} & \multicolumn{3}{|c|}{ Temperatura $^{\circ} \mathrm{C}$} \\
\hline & & Mínima & Máxima & Média \\
\hline 28/10 a 03/11 & 0,9 & 16,3 & 29,3 & 22,8 \\
\hline 04 a 10/11 & 26,9 & 17,7 & 29,3 & 23,5 \\
\hline 11 a $17 / 11$ & 59,8 & 19,5 & 27,1 & 23,3 \\
\hline 18 a 24/11 & 82,7 & 19,5 & 30,6 & 25,1 \\
\hline 25/11 a 01/12 & 20,0 & 19,5 & 30,4 & 24,9 \\
\hline 02 a 05/12 & 7,4 & 18,1 & 29,4 & 23,7 \\
\hline 09 a $15 / 12$ & 25,2 & 20,2 & 28,3 & 24,2 \\
\hline 16 a $22 / 12$ & 93,3 & 21,0 & 30,4 & 25,7 \\
\hline 23 а 29/12 & 25,8 & 18,7 & 26,7 & 22,7 \\
\hline 30/12 a 05/01 & 102,8 & 19,5 & 29,6 & 24,6 \\
\hline 06a 12/01 & 62,7 & 20,3 & 28,4 & 24,4 \\
\hline 13 а 19/01 & 37,4 & 18,9 & 24,8 & 21,8 \\
\hline 20 a 26/01 & 67,3 & 20,7 & 31,9 & 26,3 \\
\hline 27/01 a 02/02 & 47,0 & 21,6 & 31,0 & 26,3 \\
\hline 03 а 09/02 & 19,4 & 18,7 & 27,1 & 22,9 \\
\hline 10 а $16 / 02$ & 66,1 & 18,8 & 30,4 & 24,6 \\
\hline 17 а 23/02 & 119,6 & 19,6 & 27,4 & 23,5 \\
\hline 24/02 a 02/03 & 60,6 & 18,9 & 28,6 & 23,8 \\
\hline 03 а 09/03 & 12,6 & 18,8 & 32,1 & 25,5 \\
\hline 10 a $16 / 03$ & 0,0 & 19,2 & 32,3 & 25,7 \\
\hline 17 a 23/03 & 75,2 & 19,7 & 29,9 & 24,8 \\
\hline 24 a $27 / 03$ & 13,7 & 19,9 & 28,5 & 24,2 \\
\hline
\end{tabular}

Fonte: Seção de Climatologia Agrícola - Instituto Agronômico de Campinas

\subsection{Instalação e condução do experimento}

Antecedendo a instalação do experimento foram coletadas amostras de solo do local do ensaio e realizadas as análises fisico-químicas, segundo metodologia proposta por Raij \& Quaggio (1983), cujos resultados estão contidos nas Tabelas 2 e 3. 
Tabela 2. Características químicas do solo, na profundidade de 0-30 cm, 2001

\begin{tabular}{cccccccccc}
\hline M.O. & $\mathrm{pH}$ & P resina & $\mathrm{K}$ & $\mathrm{Ca}$ & $\mathrm{Mg}$ & $\mathrm{H}+\mathrm{Al}$ & $\mathrm{SB}$ & $\mathrm{CTC}$ & $\mathrm{V}$ \\
$\left(\mathrm{g} / \mathrm{dm}^{3}\right)$ & $\left(\mathrm{CaCl}_{2}\right)$ & $\left(\mathrm{mg} / \mathrm{dm}^{-3}\right)$ & & & $\mathrm{Mmolc} \mathrm{dm}^{-3}$ & & & $(\%)$ \\
25 & 5,4 & 7,1 & 2,00 & 30,0 & 10,0 & 31,0 & 42,0 & 73,0 & 57,5 \\
\hline
\end{tabular}

Fonte: LAGRO - Laboratório Agronômico S/C Ltda. Campinas-SP

Tabela 3. Características físicas do solo, na profundidade de 0-30 cm, 2001

\begin{tabular}{|c|c|c|c|c|c|c|c|c|}
\hline \multicolumn{5}{|c|}{ Composição granulométrica (\%) } & \multicolumn{2}{|c|}{ Densidades $\left(\mathrm{g} / \mathrm{cm}^{3}\right)$} & \multirow[t]{2}{*}{ Classe } & \multirow[t]{2}{*}{ Sub-classe } \\
\hline $\begin{array}{l}\text { areia } \\
\text { grossa }\end{array}$ & $\begin{array}{c}\text { areia } \\
\text { fina }\end{array}$ & limo & argila & cascalho & aparente & real & & \\
\hline 2,5 & 79,5 & 0,0 & 18,0 & 0,0 & 1,0 & 1,81 & $\begin{array}{c}\text { Limo areno } \\
\text { barrento }\end{array}$ & $\begin{array}{c}\text { Fino areno } \\
\text { barrento }\end{array}$ \\
\hline
\end{tabular}

Fonte: ICASA. Campinas - SP.

O solo foi preparado através de uma aração e duas gradagens a 0,2 m de profundidade, sendo a primeira gradagem logo após a aração e a segunda, às vésperas da semeadura, utilizando-se implementos de discos.

A semeadura do arroz, cultivar Epagri 109, foi realizada no dia 30/10/2001, utilizando-se a densidade de $140 \mathrm{~kg} \cdot \mathrm{ha}^{-1}$ de sementes e espaçamento de 0,33 m entre linhas. As sementes foram adquiridas no posto de sementes de Taubaté-SP, apresentando 98\% de germinação e 96\% de pureza física. A emergência das plântulas ocorreu em 10/11/2001, 11 dias após a semeadura, e não ocorreram problemas fitossanitários que interferissem no desenvolvimento da cultura.

A adubação de base foi realizada simultaneamente com a semeadura e constou da aplicação de $17 \mathrm{~kg}$ de N, $60 \mathrm{~kg}$ de $\mathrm{P}_{2} \mathrm{O}_{5}$ e 34 kg de $\mathrm{K}_{2} \mathrm{O}_{\text {.ha }}{ }^{-1}$, através da fórmula 04-14-08 e a adubação de cobertura foi realizada manualmente 40 dias após a emergência das plantas, utilizando-se 50 kg.ha ${ }^{-1}$ de $\mathrm{N}$ na forma de uréia, conforme recomendado pela EPAGRI (1997). 
A área foi inundada 35 dias após a semeadura, mantendo-se uma lâmina uniforme de água com $15 \mathrm{~cm}$ de altura, até 10 dias antes da colheita, que foi efetuada manualmente 148 dias após a semeadura.

O histórico da área do experimento era o da não presença de plantas do gênero Aeschynomene nos últimos 5 anos e um baixo nível de infestação com plantas daninhas de outras espécies, motivo da escolha desta área para o desenvolvimento do experimento.

A semeadura do Aeschynomene rudis Benth. foi efetuada no mesmo dia da semeadura do arroz, utilizando-se um quadrado de madeira de $1 \mathrm{~m}$ de lado, com 36 furos eqüidistantes $18 \mathrm{~cm}$ cada, onde eram depositadas as sementes a uma profundidade de 2 cm. Foram demarcados 10 ( 2 x 5) quadrantes de um metro quadrado cada, por parcela, e semeadas quatro diferentes densidades de Aeschynomene rudis Benth., para se obter 3, 6, 12 e 24 plantas por metro quadrado, perfazendo um total de 30, 60, 120 e 240 plantas por parcela, nos respectivos tratamentos. A emergência das plantas ocorreu 10 dias após e as densidades foram aferidas aos 14 e 28 dias após a semeadura quando se procedeu ao desbaste do excesso de plantas para cada tratamento.

As sementes do Aeschynomene rudis Benth. foram adquiridas da Shokucho do Brasil situada no município de Engenheiro Coelho-SP em junho de 2001, sendo selecionadas e armazenadas em câmara fria e trinta dias antes da instalação do experimento, foi efetuado um teste de germinação em laboratório para se determinar a densidade de semeadura em cada tratamento. Foi verificada uma taxa de $70 \%$ de germinação das sementes, porém para os cálculos de semeadura , tomou-se como base uma taxa de 65\%, com a finalidade de se obter um número maior de plantas para um posterior desbaste.

Para o controle de poáceas foi realizada uma aplicação de fenoxaprop-p-ethyl na dose de 69 g.ha $^{-1} 14$ dias após a semeadura, e as ciperáceas foram controladas através do arranquio manual.

Para a aplicação dos herbicidas foi utilizado um pulverizador costal, à pressão constante de 2,5 bar, munido de barra com 6 bicos XR teejet 110015 jato plano, espaçados de $0,4 \mathrm{~m}$. O gasto de calda foi equivalente a $200 \mathrm{~L} \mathrm{ha}^{-1}$ promovendo uma 
excelente cobertura das plantas daninhas. A água utilizada encontrava-se limpa e com pH de 6,1, determinado com equipamento específico modelo Checker digital.

A dosagem dos produtos foi feita utilizando-se balança (PB 3002, Mettler toledo) e pipeta (Transferpettor, Brand) digitais de duas casas decimais.

A primeira aplicação, tratamentos 6 a 9, foi realizada em 27/11/2001, 28 dias após a semeadura, das $12: 12$ às $12: 30$ horas, com temperatura de $29^{\circ} \mathrm{C}$, umidade relativa do ar de 70\%, ausência de ventos, nebulosidade de 80\% e solo úmido. O Aeschynomene rudis Benth. encontrava-se no estádio de 4 folhas verdadeiras e o arroz com 1 perfilho.

A segunda aplicação, tratamentos 10 a 13, foi realizada em 04/12/2001, 35 dias após a semeadura, das 17:20 às 17:35 horas, com temperatura de $27^{\circ} \mathrm{C}$, umidade relativa do ar de 65\%, ausência de ventos, nebulosidade de 20\% e solo úmido. O Aeschynomene rudis Benth. encontrava-se no estádio de 6 folhas verdadeiras e a cultura do arroz com 2 perfilhos.

Não ocorreram chuvas no intervalo de 0 a 6 horas após as aplicações.

No momento da colheita todas as plantas de Aeschynomene rudis Benth. foram retiradas manualmente das parcelas a fim de facilitar a operação.

\subsection{Delineamento experimental}

O delineamento experimental utilizado foi o de blocos ao acaso com treze tratamentos e quatro repetições totalizando cinqüenta e duas parcelas. As parcelas foram constituídas de nove linhas de arroz com cinco metros de comprimento sendo considerada como área útil as sete linhas centrais de cada parcela. Entre cada parcela foi deixado um espaço de um metro para permitir o caminhamento dentro do experimento.

\subsection{Tratamentos}

Foram estudadas quatro diferentes densidades de Aeschynomene rudis Benth., 3, 6, 12 e 24 plantas por metro quadrado, e seu controle pelo herbicida ethoxysulfuron aplicado na dose de 80 g.ha ${ }^{-1}$ em duas épocas, 4 e 6 folhas do Aeschynomene rudis 
Benth.(Tabela 4.). Na calda herbicida foi utilizado como surfactante o lauril éter sulfato de sódio na dose de $0,3 \%(\mathrm{v} / \mathrm{v})$.

\subsection{Produtos utilizados}

\subsubsection{Ethoxysulfuron}

O herbicida ethoxysulfuron cujo nome químico é o 1-(4,6-dimethoxypyrimidin2-yl)-3-(2-ethoxyphenoxysulfonyl)urea, $\mathrm{C}_{15} \mathrm{H}_{18} \mathrm{~N}_{4} \mathrm{O}_{7} \mathrm{~S}$, pertence ao grupo das sulfoniluréias.

Tabela 4. Tratamentos utilizados no experimento com Aeschynomene rudis Benth. Taubaté - SP, 2001

\begin{tabular}{|c|c|c|c|}
\hline \multirow[t]{2}{*}{ Tratamento } & \multirow{2}{*}{$\begin{array}{c}\text { Dose } \\
\text { g/ha \%v/v }\end{array}$} & \multicolumn{2}{|c|}{ Aeschynomene rudis Benth. } \\
\hline & & Plantas $/ \mathrm{m}^{2}$ & Estádio na aplicação \\
\hline 1. Testemunha & & 0 & - \\
\hline 2. Testemunha & & 3 & - \\
\hline 3. Testemunha & & 6 & - \\
\hline 4. Testemunha & & 12 & - \\
\hline 5. Testemunha & & 24 & - \\
\hline 6. Ethoxysulfuron $^{1}+$ adjuvante $^{2}$ & $80+0,3$ & 3 & 4 folhas \\
\hline 7. Ethoxysulfuron $^{1}+$ adjuvante $^{2}$ & $80+0,3$ & 6 & 4 folhas \\
\hline 8. Ethoxysulfuron $^{1}+$ adjuvante $^{2}$ & $80+0,3$ & 12 & 4 folhas \\
\hline 9. Ethoxysulfuron $^{1}+$ adjuvante $^{2}$ & $80+0,3$ & 24 & 4 folhas \\
\hline 10. Ethoxysulfuron ${ }^{1}+$ adjuvante $^{2}$ & $80+0,3$ & 3 & 6 folhas \\
\hline 11. Ethoxysulfuron ${ }^{1}+$ adjuvante $^{2}$ & $80+0,3$ & 6 & 6 folhas \\
\hline 12. Ethoxysulfuron ${ }^{1}+$ adjuvante $^{2}$ & $80+0,3$ & 12 & 6 folhas \\
\hline 13. Ethoxysulfuron ${ }^{1}+$ adjuvante $^{2}$ & $80+0,3$ & 24 & 6 folhas \\
\hline
\end{tabular}

${ }^{1}$ Gladium (ethoxysulfuron 600 g.kg ${ }^{-1}$ )

${ }^{2}$ Hoefix (lauril éter sulfato de sódio 279 g.L ${ }^{-1}$ ) 
Atualmente encontra-se registrado para as culturas de arroz e da cana-de-açúcar com intervalos de segurança de 50 e 150 dias respectivamente. Sua solubilidade em água é de 1353 ppm, densidade de 1,48 g.cm ${ }^{-3}$ e pressão de vapor de 4,95 x 10 $0^{-7} \mathrm{mmHg}$. Não é inflamável às temperaturas normais de uso e armazenagem e não corrosivo para o equipamento de aplicação. É compatível com outros herbicidas importantes na cultura do arroz como propanil e fenoxaprop-p-ethyl. Formulado em grânulos dispersíveis em água contendo 600 gramas do ingrediente ativo por quilograma do produto comercial. A absorção ocorre principalmente pelas folhas, sendo translocado acro e basipetal, inibindo a enzima acetolactato sintase (ALS) também conhecida como acetohidroxiácido sintetase (AHAS). O ethoxysulfuron é rapidamente metabolizado nas culturas do arroz e da cana-de-açúcar. Possui baixa a moderada lixiviação e adsorção aos colóides do solo. Sua degradação é principalmente microbiana, não havendo risco de persistência ou acúmulo, tendo uma meia vida no solo de 6 a 18 dias. Ethoxysulfuron apresenta $\mathrm{DL}_{50}$ oral superior a 5000 mg. $\mathrm{kg}^{-1}$ e $\mathrm{DL}_{50}$ dérmica superior a 4000 mg. $\mathrm{kg}^{-1}$ (ratos), não é carcinogênico nem teratogênico, pertencente a classe toxicológica III - medianamente tóxico. A ecotoxicologia do produto formulado é muito favorável sendo que a $\mathrm{DL}_{50}$ para aves é superior a $2000 \mathrm{mg} . \mathrm{kg}^{-1}, \mathrm{CL}_{50}$ para peixes maior que 78,4mg.L.-1, $\mathrm{DL}_{50} \mathrm{em}$ abelhas igual a $1000 \mathrm{mg}$ por abelha e a $\mathrm{CL}_{50}$ para minhocas maior que $1000 \mathrm{mg} \cdot \mathrm{kg}^{-1} \mathrm{de}$ solo (Rodrigues \& Almeida, 1998).

A marca comercial disponível no mercado atualmente é o Gladium sendo largamente utilizado para o controle de dicotiledôneas e ciperáceas na cultura do arroz, nas doses de 100 a 133 g.ha ${ }^{-1}$ e está registrado no Ministério da Agricultura sob o número 06698. Foi descoberto e inicialmente estudado por Hoechst AG, passando mais tarde a ser desenvolvido pela AgrEvo GmbH, sendo comercializado atualmente pela Bayer CropScience.

\subsubsection{Lauril éter sulfato de sódio}

Espalhante adesivo do grupo químico alquil sulfonato. É recomendado na adição à calda herbicida para aplicações pós-emergentes, com a finalidade de aumentar ou 
melhorar a ação de contato, assim como auxiliar a penetração dos herbicidas, melhorando a eficácia dos produtos e a velocidade de ação.

A formulação atualmente comercializada é uma solução aquosa concentrada contendo 279 g/L de lauril éter sulfato de sódio, de classe toxicológica I.

O produto está devidamente registrado no Ministério da Agricultura sob número 0738903, tendo como nome comercial Hoefix. É indicado nas doses de 0,2 a 0,8 \% (v/v), podendo ser aplicado com pulverizador costal manual ou motorizado e aplicação tratorizada ou aérea, em função do herbicida a ser utilizado. O intervalo de segurança, é o mesmo estabelecido para o herbicida ao qual foi adicionado (MAPA, 2003).

\subsubsection{Arroz cultivar Epagri 109}

O cultivar Epagri 109 foi lançado no ano de 1996 pela Empresa de Pesquisa Agropecuária e Extensão Rural de Santa Catarina. Rapidamente foi introduzida por alguns produtores de arroz do Vale do Paraíba, principal região orizícola do Estado de São Paulo, onde encontrou grande aceitação devido sua boa adaptação às condições de plantio da região e a alta qualidade dos grãos na cocção, principalmente..

O Epagri 109 é originário do cruzamento entre CT 7347 e IR 21015-72-3-3-3-1, apresenta ciclo semi tardio de 142 dias, altura média de 0,95 m, bom perfilhamento, resistência ao acamamento, toxidez por ferro e à bruzone e moderada resistência à mancha de grãos. Seus grãos são do tipo longo fino, apresenta rendimento de engenho de 55\% e a produção média verificada na região do Vale do Paraíba é de 5800 kg.ha-1 (IRGA, 2001; CATI, 2003).

\subsubsection{Aeschynomene rudis Benth.}

Aeschynomene rudis Benth. é uma planta anual, reproduzida por sementes, que têm longa viabilidade no solo e germinação desuniforme, ocorrendo mesmo em solo inundado. As plântulas têm condições de sobreviver quando a lâmina de água que cobre o solo não é muito alta, sendo o ambiente de solo encharcado com plena insolação ideal 
para essa espécie como o de lavouras de arroz irrigado (Kissmann \& Groth, 1999; Lorenzi, 2000b).

As folhas apresentam pecíolos guarnecidos por um par de estípulas peltadas, com 7-15 mm de comprimento, de segmento superior agudo e inferior arredondado ou truncado. As estípulas têm curta persistência. O limbo é do tipo composto, com até 12 cm de comprimento por $4 \mathrm{~cm}$ de largura, paripinado com 15-20 pares de folíolos elíptico-arredondados com 7-20 mm de comprimento por 3-4 mm de largura, podendo conter algumas vezes pêlos setulosos nas margens. As folhas são sensitivas, fechando-se quando tocadas ou na ausência de luz; ou de umidade (Fernandes, 1996; Kissmann \& Groth, 1999).

A inflorescência é hispidulosa, com rácemos axilares flexuosos, com 4-10 cm de comprimento e 1 a 6 flores com 8-15 mm de comprimento. As flores são guarnecidas por brácteas subovais agudas, com 3-4 mm de comprimento, ciliadas e bractéolas ovaloblongas, agudas com 2-3 mm de comprimento e também ciliadas. O cálice apresenta 5$8 \mathrm{~mm}$ de comprimento, bilabiado, estandarte com cerca de $14 \mathrm{~mm}$ de comprimento e lâmina orbicular de $12 \mathrm{~mm}$ de comprimento. A corola é papilionada, de quilha falcada, de coloração amarelo-alaranjada com estrias avermelhadas. O androceu é isodelfo com 5+5 estames e o gineceu apresenta ovário linear estipitado, estilo curvado (Fernandes, 1996; Kissmann \& Groth, 1999).

Os frutos são ascendentes, lomentos alongados, comprimidos, lineares, levemente arqueados, com 3-5 cm de comprimento e 4-6 mm de largura, com 7-12 artículos retangulares, esparsamente híspidos a glabros, indeiscentes, unisseminados, geralmente muricados, com a borda superior inteira e a inferior crenada. (Fernandes, 1996; Kissmann \& Groth, 1999). Suas sementes vão de alongado-reniformes a elípticoreniformes, levemente comprimidas e elípticas em seção transversal, com 3,6-4,0 mm de comprimento por 2,5-2,6 mm de largura na região do hilo e 1,8-2,2 mm de espessura; lados levemente convexos; base e ápice arredondados; margem dorsal convexa e ventral côncava, com hilo elíptico, afundado, com 1,1-1,2 mm de comprimento, castanho-escuro com fenda linear mais clara ou da mesma coloração do hilo e circundado por um colar mais claro, proeminente e de aspecto cartilaginoso; face bilobada, curta, mais clara em 
sementes novas e mais escura em sementes velhas; lóbulo radicular com ponta da radícula protuberante; tegumento coriáceo, castanho-escuro ou quase preto e quando imaturo algo esverdeado, com superfície lisa e glabra, levemente brilhante; embrião axial curvo, com radícula inflectida e que forma um ângulo reto com os cotilédones reniformes (Kissmann \& Groth, 1999).

De uma maneira prática, Aeschynomene rudis Benth. diferencia-se das outras espécies do gênero por apresentar folíolos com margens geralmente inteiras, com pêlos glandulares menos abundantes que em $A$. denticulata e com vagem (lomento) de margem inferior sinuosa (Lorenzi, 2000b).

\subsection{Avaliações}

Para uma maior homogeneidade das avaliações do número de plantas por metro, número de colmos por metro, altura de plantas, número de panículas por metro, número de espiguetas por panícula, número de grãos formados por panícula e tamanho das panículas, foram demarcados três locais de um metro cada na $2^{\mathrm{a}}, 4^{\mathrm{a}}$ e $6^{\mathrm{a}}$ linhas da cultura, em cada parcela, procedendo assim, as avaliações sempre nos mesmos locais.

\subsubsection{Número de plantas por metro}

Foram feitas as contagens do número de plantas por metro, nos três locais previamente marcados, por parcela, em 27/11/2001, 27 dias após a semeadura.

\subsubsection{Número de colmos por metro}

Com a finalidade de verificar o perfilhamento da cultura foram efetuadas as contagens, no momento da colheita, do número de colmos por metro, nos três locais previamente marcados, por parcela. 


\subsubsection{Altura de plantas}

Foram medidas as alturas de 10 plantas, no momento da colheita, nos três locais previamente marcados, por parcela, tomando-se como referência o solo até o primeiro nó da raquis.

\subsubsection{Número de panículas por metro}

Com a finalidade de verificar o perfilhamento útil da cultura, foram efetuadas as contagens, no momento da colheita, do número de panículas por metro, nos três locais previamente marcados, por parcela.

\subsubsection{Comprimento de panículas}

Foram medidos os comprimentos de 10 panículas, amostradas no momento da colheita, nos três locais previamente marcados, por parcela. Tomou-se como base a medida entre o primeiro nó da raquis e a inserção do último grão da panícula.

\subsubsection{Número de espiguetas por panículas}

Foram feitas contagens do número de espiguetas em 10 panículas, amostradas no momento da colheita, nos três locais previamente marcados, por parcela

\subsubsection{Número de grãos formados por panícula}

Foram efetuadas as contagens do número de grãos cheios em 10 panículas amostradas no momento da colheita, nos três locais previamente marcados, dentro de cada parcela. 


\subsubsection{Rendimento de grãos}

A colheita foi realizada manualmente, quando os grãos apresentavam umidade em torno de $20 \%$, sendo colhidas as $3^{\mathrm{a}}$ e $5^{\mathrm{a}}$ linhas de cada parcela. Após a colheita o material foi transportado para Paulínia-SP onde se realizou manualmente a trilha, secagem à sombra e limpeza do material, separando-se a palha e os grãos chochos através de abanação com o uso de peneiras. Com o material limpo determinou-se a umidade e a massa de grãos colhidos, com correção da umidade para 13\% base úmida e transformando o resultado em quilos por hectare.

\subsubsection{Eficiência do herbicida}

Foram realizadas avaliações de controle aos 7, 14, 28, 42 dias após a aplicação do herbicida e uma avaliação de pré-colheita, efetuada aos 148 dias após a semeadura, tomando-se como base uma escala visual em percentagem onde $0 \%$ representa ausência de controle e 100\% morte total das plantas de Aeschynomene rudis Benth..

\subsubsection{Fitointoxicação da cultura}

Foram realizadas avaliações de fitointoxicação aos 7, 14, 28 e 42 dias após a aplicação do herbicida e uma avaliação de pré-colheita, efetuada aos 148 dias após a semeadura, tomando-se como base uma escala visual em percentagem onde $0 \%$ representa ausência de sintomas e 100\% morte total das plantas de arroz.

\subsubsection{1 Índice para colheita mecânica}

Devido às características que apresenta a planta de Aeschynomene rudis Benth., foi realizada uma avaliação no momento da colheita, para determinar a facilidade da realização do processo, caso fosse efetuado mecanicamente, de acordo com uma escala visual variando de 0 a 5 , onde: 
0 - impossibilidade de colheita

1 - muito difícil

2 - difícil

3 - médio

4 -fácil

5 -muito fácil

\subsubsection{Análise estatística}

A análise estatística foi dividida em três etapas: a) análise do efeito de densidades de Aeschynomene rudis Benth.; b) efeito de épocas de aplicação do ethoxysulfuron (pósemergência precoce - EPO e pós-emergência mediana - MPO da planta daninha); c) interação entre épocas de aplicação do herbicida dentro de cada densidade da planta daninha.

Para a análise de variância utilizou-se o teste $\mathrm{F}$ ao nível de 5\% de probabilidade. Para o efeito de épocas de aplicação e suas interações foi empregado o teste de Tukey à $5 \%$, e para o efeito de densidades e suas interações foi empregado ajustes matemáticos com significado biológico. 


\section{RESULTADOS E DISCUSSÃO}

\subsection{Número de plantas por metro}

A análise de variância para este parâmetro apresentou valores de $\mathrm{F}$ não significativos. Os resultados estão representados nas Tabelas 13 e 14. Estes resultados confirmam o esperado, de que as plantas de Aeschynomene rudis Benth. não interferem na emergência da cultura por apresentarem germinação mais lenta que o arroz.

\subsection{Número de colmos por metro}

O teste $\mathrm{F}$ foi significativo para a contagem do número de colmos por metro para o efeito de tratamentos, densidades e interação entre tratamentos x densidades ao nível de 5\% de probabilidade. Não foram observadas diferenças entre as épocas de aplicação de ethoxysulfuron (Tabelas 5 e 14). Nos tratamentos com densidade de 3 plantas de $A$. rudis não houve diferença significativa entre as épocas de aplicação do herbicida e a testemunha. Foi constatada uma redução significativa de 18,55\% com o aumento da densidade de $A$. rudis de 0 para 24 plantas por metro quadrado (Tabela 13). A equação de ajuste para o efeito de densidades é do tipo linear mostrando um decréscimo do número de colmos com o aumento do número de plantas de $A$. rudis por metro quadrado, dentro do tratamento testemunha. Esse decréscimo é explicado pelo menor perfilhamento do arroz quando submetido à competição por espaço. Por outro lado, características como número de colmos e panículas variam também em função do cultivar utilizado, temperatura do solo, disponibilidade de nitrogênio, lâmina de irrigação e etc (Epagri, 1997). 


\subsection{Altura das plantas de arroz}

Na maior densidade de $A$. rudis, observamos uma redução de 8,3\% na altura das plantas de arroz quando comparado com o tratamento sem a presença da planta daninha, porém a análise de variância revelou valores de F não significativos (Tabelas 6 e 14).

Em relação a este resultado, Menezes et al. (2000) trabalhando com diferentes densidades de $A$. denticulata Rudd. também não verificaram redução significativa na altura das plantas de arroz com o aumento da densidade desta planta daninha. Por outro lado, Andres \& Menezes (1997) verificaram diferenças na estatura das plantas de arroz e na esterilidade das espiguetas em parcelas com 247 plantas de Echinochloa crusgalli e 2 plantas de $A$. denticulata por metro quadrado quando comparadas com áreas tratadas com o herbicida bispyribac-sodium em pós-emergência precoce das plantas daninhas, isto se deve ao rápido crescimento inicial de $E$. crusgalli quando comparado às plantas de arroz e $A$. denticulata exercendo assim, forte competição com a cultura pelos fatores de produção, prejudicando seu desenvolvimento.

\subsection{Número de panículas por metro}

Os resultados encontrados quando analisados a $5 \%$ de probabilidade, apresentaram valores de F significativos para os fatores tratamentos, densidades e para a interação entre os dois. Foi observada uma redução de 28,9\% no número de panículas para o tratamento com a maior densidade de $A$. rudis sem a aplicação de herbicida, quando comparado com o tratamento sem a planta daninha (Tabela 13). Para o efeito de densidades o melhor ajuste foi obtido através de equação linear com decréscimo do número de panículas por metro com o aumento do número de plantas de A. Rudis por metro quadrado. Este resultado está de acordo com o encontrado por Menezes et al. (2000) que afirmam ser, o número de panículas por metro, o componente de rendimento de grãos mais afetado pelo aumento da densidade de $A$. denticulata. Os tratamentos com a densidade de 3 plantas de $A$. rudis, com ou sem herbicida, não diferiram estatisticamente entre si. Para os demais tratamentos com herbicida, não foi encontrada 
diferença significativa entre as épocas de aplicação dentro de cada densidade de $A$. Rudis (Tabelas 7 e 14).

\subsection{Comprimento de panículas}

A análise da variância revelou valores de $\mathrm{F}$ significativos ao nível de $5 \%$ de probabilidade para os fatores tratamentos, densidades e para a interação entre eles. $\mathrm{O}$ comprimento das panículas apresentou uma redução de $15,46 \%$ no tratamento com a maior densidade de $A$. rudis em relação ao sem a presença da planta daninha. A equação de ajuste que representa o efeito de densidades no comprimento de panículas é do tipo linear (Tabela 13). Na densidade de 3 plantas não foi observada diferença entre os tratamentos com e sem herbicida. Para as demais densidades não existe diferença entre as épocas de aplicação mas apenas entre tratado e não tratado com ethoxysulfuron (Tabelas 8 e 14). A diferenciação da panícula ocorre entre 50 e 80 dias após o plantio da cultura dependendo do ciclo do cultivar utilizado, sendo assim, condições desfavoráveis como à competição ocasionada pelas plantas daninhas afetam negativamente a formação das panículas de arroz. Por ser de ciclo longo o cultivar utilizado no experimento, a diferenciação da panícula ocorreu por volta dos 80 dias, quando as plantas de arroz estavam em plena competição pelos fatores de produção com as plantas de $A$. rudis.

\subsection{Número de espiguetas por panícula}

Para o número de espiguetas por panícula foram observados efeitos dos tratamentos, densidades e da interação tratamentos x densidades ao nível de $5 \%$ de probabilidade. Os resultados mostram uma diminuição de 31,24\% entre os tratamentos com 0 e 24 plantas de $A$. rudis por metro quadrado. Para o efeito de densidades o melhor ajuste foi obtido com equação linear (Tabela 13). Não foi verificada diferença significativa entre as duas épocas de aplicação do herbicida, mas ambas diferiram da testemunha dentro de cada densidade (Tabelas 9 e 14). Logo após a diferenciação da panícula inicia-se o seu processo de desenvolvimento. Nessa etapa, o primórdio da 
espigueta diferencia-se e forma junto com a ráquis a panícula. Esta fase é muito crítica com relação a fatores adversos como a competição ocasionada pelas plantas de A.rudis, uma vez que é durante a diferenciação do primórdio das espiguetas que fica determinado seu número total na panícula. Este fato explica os valores decrescentes encontrados para número de espiguetas por panícula em função do aumento da densidade de $A$. rudis.

\subsection{Número de grãos formados por panícula}

A análise de variância para este parâmetro apresentou valores de F significativos para os fatores tratamentos, densidades e a interação tratamentos $\mathrm{x}$ densidades. Observou-se uma redução de 48,39\% no número de grãos formados por panícula entre as densidades de 0 e 24 plantas, sendo que essa diminuição passa a ser significativa a partir de 3 plantas por metro quadrado. A equação de ajuste obtida é do tipo linear onde o número de grãos formados por panícula diminui à medida que aumenta a densidade de A. rudis (Tabela 13). Os tratamentos com ethoxysulfuron diferiram da testemunha dentro de cada densidade, mas não se verificou diferenças entre as duas épocas de aplicação do mesmo (Tabelas 10 e 14). A primeira folha, logo abaixo da panícula, é a grande responsável pelo enchimento dos grãos através da produção de carboidratos que são translocados. Com o sombreamento ocasionado pelas plantas de $A$. rudis a eficiência fotossintética dessa folha ficou prejudicada diminuindo a produção de fotoassimilados e consequentemente o número de grãos formados por panícula. Abud (1991) observou diferenças significativas no número de grãos formados por panícula trabalhando com populações de 36 e 4 plantas de E. crusgalli e $A$. sensitiva por metro quadrado,

respectivamente. Resultado similar foi verificado por Xavier \& Pinto (1985) com densidades de 62 plantas de Aeschynomene rudis e 9 plantas de $A$. hispida por metro quadrado. 


\subsection{Rendimento de grãos}

A análise de variância para o rendimento de grãos mostrou valores de $\mathrm{F}$ significativos ao nível de 5\% de probabilidade para o efeito de tratamentos, densidades e para a interação tratamentos x densidades. Considerando apenas o efeito de densidades, todos os tratamentos diferiram estatisticamente entre si, sendo observada uma redução de 57,50\% no rendimento de grãos entre os tratamentos com 0 e 24 plantas de $A$. rudis por metro quadrado. O melhor ajuste foi obtido com equação linear mostrando um decréscimo no rendimento com o aumento da densidade de $A$. rudis, onde para cada aumento de uma planta de $A$. rudis por metro quadrado, resultou em um decréscimo de 119,73 kg.ha-1 no rendimento de grãos do arroz (Tabela 13). Para o efeito de tratamentos, dentro de cada densidade, não se observou diferenças entre as épocas de aplicação, porém ambas diferiram da testemunha (Tabelas 11 e 14). Os decréscimos de rendimento observados estão de acordo com os trabalhos encontrados na literatura correlata (Xavier \& Pinto, 1985; Andrade 1986, 1987; Abud, 1991 a, b, c, 1993; Constantin et al., 1995; Andres \& Menezes, 1997; Bizzi \& Andres, 2001; Menezes et al., 2001).

\subsection{Eficiência do herbicida ethoxysulfuron}

Os resultados obtidos para a eficácia do herbicida ethoxysulfuron, quando submetidos à análise de variância ao nível de 5\% de probabilidade, apresentaram valores de $\mathrm{F}$ significativos. As médias da porcentagem de controle de A. rudis estão representadas na Tabela 16. Aos 9 dias após a segunda aplicação (DAB), observa-se um controle superior a 95,8\% para a pulverização em pós-emergência precoce diferindo estatisticamente da testemunha capinada e dos tratamentos em pós-emergência mediana que apresentaram nível de controle entre 82,6 a 85,5\%. Com 17 DAB, verificou-se um controle de 100,0\% para a primeira aplicação, sendo igual à testemunha capinada e acima de 96,5\% para a segunda aplicação, diferindo estatisticamente da primeira. Aos 58 DAB, encontramos valores superiores a 99,7\% de controle para a primeira aplicação não 
diferindo da testemunha capinada e acima de 96,8\% para a segunda época de aplicação que, estatisticamente foi inferior à primeira aplicação. Situação semelhante foi verificada aos $93 \mathrm{DAB}$, onde os resultados de controle para a primeira aplicação, foram superiores a 99,7\% não diferindo da testemunha capinada e para a segunda época valores entre 95,8\% a 96,6\% sendo inferiores estatisticamente à primeira época de aplicação. A avaliação de pré-colheita foi realizada aos 108 DAB. Os resultados mostram um controle variando entre 99,1 a 99,9\%, para a primeira época de aplicação, não diferindo da testemunha capinada mas superior à segunda época que apresentou controle entre 94,6 e 95,4\%. Em todas as avaliações observou-se uma tendência de queda na eficácia do produto com o aumento da densidade da planta daninha, porém essa diferença não foi significativa para nenhuma das épocas de aplicação estudadas. Embora a diferença de controle do $A$. rudis nas duas épocas avaliadas tenha sido pequena, a primeira aplicação em plantas com até 4 folhas, foi sempre superior, diferindo estatisticamente daquela realizada quando as plantas apresentavam 6 folhas, fato este explicado pelo baixo coeficiente de variação dos dados. Mesmo assim, considera-se como excelente os resultados de controle para as duas épocas de aplicação atendendo as necessidades para o processo de colheita.

Os resultados observados, nas condições em que o herbicida ethoxysulfuron foi aplicado e com relação à sensibilidade da espécie a este produto, estão em pleno acordo com aqueles obtidos por diversos autores como Dario et al. (1995, 1997); Gelmini et al. (1997); Adoryan (2000) e Dario \& Adoryan (2000).

\subsection{Fitointoxicação à cultura}

A análise da variância encontrou valores de $\mathrm{F}$ não significativos para a fitointoxicação à cultura (Tabela 15). O herbicida ethoxysulfuron, nas duas épocas de aplicação, não causou qualquer sintoma de injúria à cultura do arroz, isto se deve ao fato do produto ser pouco translocado dentro das plantas de arroz e rapidamente degradado em compostos hidrofílicos (Kocher, 1995). Estes resultados estão de acordo com os 
encontrados por Dario et al. (1995, 1997); Gelmini et al. (1997); Adoryan (2000) e Dario \& Adoryan (2000).

\subsection{1 Índice para colheita mecânica}

A análise de variância para o índice de colheita mecânica encontrou valores de F significativos ao nível de 5\% de probabilidade para o efeito de tratamentos, densidades e para a interação entre os dois. A equação de ajuste para o efeito de densidades é do tipo linear (Tabela 13). A presença de 3 plantas de A. rudis por metro quadrado torna a operação de colheita mecânica difícil. Para as densidades de 6 e 12 plantas o processo torna-se muito difícil e com 24 plantas é impossível realizar a colheita mecanicamente. Isto ocorre pelo fato das plantas de $A$. rudis apresentarem caule espesso e parte aérea vigorosa, sendo que as folhas quando esmagadas, tornam-se extremamente pegajosas, causando a obstrução e quebra da colhedora, reduzindo sua capacidade operacional e onerando a produção. Para o efeito de tratamentos não foi verificada diferença entes as épocas de aplicação do herbicida ethoxysulfuron, mas ambas diferiram da testemunha dentro de cada densidade (Tabela 12 e 14). 
Tabela 5. Efeito da interação entre densidades de $A$. rudis dentro de épocas de aplicação do herbicida ethoxysulfuron no número de colmos de arroz irrigado. Taubaté, SP, 2001

\begin{tabular}{|c|c|c|c|}
\hline \multirow{3}{*}{ Tratamentos } & \multicolumn{3}{|c|}{ Número de colmos por metro $^{1}$} \\
\hline & \multicolumn{2}{|c|}{ Densidades de Aeschynomene rudis Benth. } & polinomiais e coeficientes de \\
\hline & 6 & 24 & determinação ${ }^{2}$ \\
\hline TEST. $^{3}$ & $122,89 \mathrm{a}^{4}$ & $107,33 \mathrm{~b}$ & $\hat{y}=11,08-0,032 x$ \\
\hline EPO & 134,06 a & 131,11 a & não significativo \\
\hline MPO & 127,25 a & $125,08 \mathrm{a}$ & não significativo \\
\hline \multicolumn{4}{|c|}{${ }^{1}$ Dados transformados em $\sqrt{ } \mathrm{x}$ para análise } \\
\hline \multicolumn{4}{|c|}{$\begin{array}{l}\text { ²A equação de regressão e seu respectivo coeficiente de determinação são relativos ao efeito de níveis de } \\
\text { densidade dentro de cada tratamento. }\end{array}$} \\
\hline \multicolumn{4}{|c|}{ ³EST, EPO e MPO são abreviações de Testemunha, pós-precoce e pós-mediana, respectivamente. } \\
\hline
\end{tabular}

Tabela 6. Efeito da interação entre de densidades de $A$. rudis dentro de épocas de aplicação do herbicida ethoxysulfuron na altura das plantas de arroz irrigado. Taubaté, SP, 2001

\begin{tabular}{|c|c|c|c|c|c|}
\hline \multirow{3}{*}{ Tratamentos } & \multicolumn{4}{|c|}{ Altura de plantas $(\mathrm{cm})^{1}$} & \multirow{3}{*}{$\begin{array}{c}\text { Significância das regressões } \\
\text { polinomiais }\end{array}$} \\
\hline & \multicolumn{4}{|c|}{ Densidades de Aeschynomene rudis Benth. } & \\
\hline & 3 & 6 & 12 & 24 & \\
\hline TEST. $^{2}$ & $74,08 a^{3}$ & 72,15 a & $73,90 \mathrm{a}$ & 67,70 a & não significativo \\
\hline EPO & 72,45 a & 74,33 a & $74,00 \mathrm{a}$ & 74,55 a & não significativo \\
\hline MPO & 73,52 a & 72,15 a & 71,88 a & 72,32 a & não significativo \\
\hline
\end{tabular}

${ }^{1}$ Dados não transformados para análise

${ }^{2}$ TEST, EPO e MPO são abreviações de Testemunha, pós-precoce e pós-mediana, respectivamente.

${ }^{3}$ Médias com letras iguais nas colunas não diferem entre si pelo teste de Tukey a 5\% de significância. As médias comparam o efeito dos tratamentos dentro de cada densidade. 
Tabela 7. Efeito da interação entre densidade de $A$. rudis e épocas de aplicação do herbicida ethoxysulfuron no número de panículas de arroz irrigado. Taubaté, SP, 2001

\begin{tabular}{|c|c|c|c|c|c|}
\hline \multirow{3}{*}{ Tratamentos } & \multicolumn{4}{|c|}{ Número de panículas por metro ${ }^{1}$} & \multirow{3}{*}{$\begin{array}{c}\text { Equações de regressão } \\
\text { polinomiais e coeficientes de } \\
\text { determinação }\end{array}$} \\
\hline & Densidad & s de Aesch & nomene r & dis Benth. & \\
\hline & 3 & 6 & 12 & 24 & \\
\hline TEST. $^{3}$ & $119,72 a^{4}$ & $107,78 \mathrm{~b}$ & $107,71 \mathrm{~b}$ & $92,56 \mathrm{~b}$ & $\hat{y}=10,953-0,0553 x$ \\
\hline EPO & $127,58 \mathrm{a}$ & $132,20 \mathrm{a}$ & 132,39 a & $128,82 \mathrm{a}$ & não significativo \\
\hline MPO & 125,56 a & $127,95 \mathrm{a}$ & 129,08 a & $122,08 \mathrm{a}$ & não significativo \\
\hline
\end{tabular}

${ }^{1}$ Dados transformados em $\sqrt{ } \mathrm{x}$

${ }^{2} \mathrm{~A}$ equação de regressão e seu respectivo coeficiente de determinação são relativos ao efeito de níveis de densidade dentro de cada tratamento.

${ }^{3}$ TEST, EPO e MPO são abreviações de Testemunha, pós-precoce e pós-mediana, respectivamente.

${ }^{4}$ Médias com letras iguais nas colunas não diferem entre si pelo teste de Tukey a 5\% de significância. As médias comparam o efeito dos tratamentos dentro de cada densidade.

Tabela 8. Efeito da interação entre densidade de $A$. rudis e épocas de aplicação do herbicida ethoxysulfuron no comprimento das panículas de arroz irrigado. Taubaté, SP, 2001

\begin{tabular}{lcccccc}
\hline & \multicolumn{3}{c}{ Comprimento de panícula $(\mathrm{cm})^{1}$} & \multicolumn{2}{c}{ Equações de regressão } \\
Tratamentos & Densidades de Aeschynomene rudis Benth. & polinomiais e coeficientes de \\
& 3 & 6 & 12 & 24 & determinação $^{2}$ \\
\hline TEST. $^{3}$ & $19,98 \mathrm{a}^{4}$ & $19,30 \mathrm{~b}$ & $19,45 \mathrm{~b}$ & $17,48 \mathrm{~b}$ & $\hat{y}=20,299-0,111 \mathrm{x}$ & $\mathrm{r}^{2}=89,61 \%$ \\
EPO $^{2}$ & $20,73 \mathrm{a}$ & $20,73 \mathrm{a}$ & $20,68 \mathrm{a}$ & $20,63 \mathrm{a}$ & não significativo \\
MPO & $20,75 \mathrm{a}$ & $20,80 \mathrm{a}$ & $20,88 \mathrm{a}$ & $20,88 \mathrm{a}$ & não significativo
\end{tabular}

${ }^{1}$ Dados não transformados para análise.

${ }^{2} \mathrm{~A}$ equação de regressão e seu respectivo coeficiente de determinação são relativos ao efeito de níveis de densidade dentro de cada tratamento.

${ }^{3}$ TEST, EPO e MPO são abreviações de Testemunha, pós-precoce e pós-mediana, respectivamente.

${ }^{4}$ Médias com letras iguais nas colunas não diferem entre si pelo teste de Tukey a 5\% de significância. As médias comparam o efeito dos tratamentos dentro de cada densidade. 
Tabela 9. Efeito da interação entre densidade de $A$. rudis e épocas de aplicação do herbicida ethoxysulfuron no número de espiguetas por panícula de arroz irrigado. Taubaté, SP, 2001

\begin{tabular}{lcccccc}
\hline & \multicolumn{2}{c}{ Número de espiguetas por panícula $^{1}$} & \multicolumn{2}{c}{ Equações de regressão } \\
Tratamentos & Densidades de Aeschynomene rudis Benth. & polinomiais e coeficientes de \\
& 3 & 6 & 12 & 24 & \multicolumn{2}{c}{ determinação $^{2}$} \\
\hline TEST. $^{3}$ & $79,83 \mathrm{~b}^{4}$ & $74,35 \mathrm{~b}$ & $70,42 \mathrm{~b}$ & $63,74 \mathrm{~b}$ & $\hat{y}=8,957-0,042 \mathrm{x}$ & $\mathrm{r}^{2}=95,32 \%$ \\
EPO & $94,30 \mathrm{a}$ & $93,84 \mathrm{a}$ & $93,95 \mathrm{a}$ & $93,92 \mathrm{a}$ & não significativo \\
MPO & $93,44 \mathrm{a}$ & $92,14 \mathrm{a}$ & $92,25 \mathrm{a}$ & 92,49 a & não significativo \\
\hline
\end{tabular}

${ }^{1}$ Dados transformados em $\sqrt{ } \mathrm{x}$

${ }^{2} \mathrm{~A}$ equação de regressão e seu respectivo coeficiente de determinação são relativos ao efeito de níveis de densidade dentro de cada tratamento.

${ }^{3}$ TEST, EPO e MPO são abreviações de Testemunha, pós-precoce e pós-mediana, respectivamente.

${ }^{4}$ Médias com letras iguais nas colunas não diferem entre si pelo teste de Tukey a 5\% de significância. As médias comparam o efeito dos tratamentos dentro de cada densidade.

Tabela 10. Efeito da interação entre densidades de $A$. rudis e épocas de aplicação do herbicida ethoxysulfuron no número de grãos formados por panícula de arroz irrigado. Taubaté, SP, 2001

\begin{tabular}{lcccccc}
\hline & \multicolumn{2}{c}{ Número de grãos formados por panícula ${ }^{1}$} & \multicolumn{2}{c}{ Equações de regressão $^{2}$} \\
Tratamentos & Densidades de Aeschynomene rudis Benth. & polinomiais e coeficientes de \\
& 3 & 6 & 12 & 24 & determinação $^{2}$ \\
\hline TEST. $^{3}$ & $67,97 \mathrm{~b}^{4}$ & $59,68 \mathrm{~b}$ & $54,82 \mathrm{~b}$ & $42,09 \mathrm{~b}$ & $\hat{y}=8,322-0,074 \mathrm{x}$ & $\mathrm{r}^{2}=96,89 \%$ \\
EPO & $85,28 \mathrm{a}$ & $84,70 \mathrm{a}$ & $83,88 \mathrm{a}$ & $84,76 \mathrm{a}$ & não significativo \\
MPO & $84,20 \mathrm{a}$ & $82,62 \mathrm{a}$ & $82,36 \mathrm{a}$ & $82,71 \mathrm{a}$ & não significativo \\
\hline
\end{tabular}

${ }^{1}$ Dados transformados em $\sqrt{\mathrm{X}}$

${ }^{2} \mathrm{~A}$ equação de regressão e seu respectivo coeficiente de determinação são relativos ao efeito de níveis de densidade dentro de cada tratamento.

${ }^{3}$ TEST, EPO e MPO são abreviações de Testemunha, pós-precoce e pós-mediana, respectivamente.

${ }^{4}$ Médias com letras iguais nas colunas não diferem entre si pelo teste de Tukey a 5\% de significância. As médias comparam o efeito dos tratamentos dentro de cada densidade. 
Tabela 11. Efeito da interação entre densidades de $A$. rudis e épocas de aplicação do herbicida ethoxysulfuron no rendimento de grãos de arroz irrigado. Taubaté, SP, 2001

\begin{tabular}{|c|c|c|c|c|c|}
\hline \multirow{3}{*}{ Tratamentos } & \multicolumn{4}{|c|}{ Rendimento $^{1}$ de grãos (kg.ha ${ }^{-1}$ ) } & \multirow{3}{*}{$\begin{array}{c}\text { Equações de regressão } \\
\text { polinomiais e coeficientes de } \\
\text { determinação }{ }^{2}\end{array}$} \\
\hline & Densidad & de $A e s c$ & nomene 1 & is Benth. & \\
\hline & 3 & 6 & 12 & 24 & \\
\hline TEST. $^{3}$ & $4400 b^{4}$ & $3808 \mathrm{~b}$ & $3335 \mathrm{~b}$ & $2475 b$ & $\hat{y}=4471,15-85,94 x$ \\
\hline EPO & 5918 a & 5929 a & 5892 a & 5808 a & não significativo \\
\hline MPO & 5827 a & 5758 a & 5644 a & 5522 a & não significativo \\
\hline
\end{tabular}

${ }^{1}$ Dados não transformados para análise.

${ }^{2}$ A equação de regressão e seu respectivo coeficiente de determinação são relativos ao efeito de níveis de densidade dentro de cada tratamento.

${ }^{3}$ TEST, EPO e MPO são abreviações de Testemunha, pós-precoce e pós-mediana, respectivamente.

${ }^{4}$ Médias com letras iguais nas colunas não diferem entre si pelo teste de Tukey a 5\% de significância. As médias comparam o efeito dos tratamentos dentro de cada densidade.

Tabela 12. Efeito da interação entre densidades de $A$. rudis e épocas de aplicação do herbicida ethoxysulfuron no índice para colheita mecânica em arroz irrigado. Taubaté, SP, 2001

\begin{tabular}{|c|c|c|c|c|c|}
\hline \multirow{3}{*}{ Tratamentos } & \multicolumn{4}{|c|}{ Índice colheita mecânica ${ }^{1}$ (escala 0-5) } & \multirow{3}{*}{$\begin{array}{c}\text { Equações de regressão } \\
\text { polinomiais e coeficientes } \\
\text { de determinação }{ }^{2}\end{array}$} \\
\hline & Densidac & de $A e s c$ & iomene & is Benth. & \\
\hline & 3 & 6 & 12 & 24 & \\
\hline TEST. $^{3}$ & $2,19 b^{4}$ & $1,16 \mathrm{~b}$ & $1,16 \mathrm{~b}$ & $0,22 \mathrm{~b}$ & $\hat{y}=1,774-0,028 x$ \\
\hline EPO & 5,00 a & 5,00 a & $5,00 \mathrm{a}$ & 5,00 a & não significativo \\
\hline MPO & 4,67 a & $4,80 \mathrm{a}$ & 4,87 a & 4,57 a & não significativo \\
\hline
\end{tabular}

${ }^{1}$ Dados transformados em $\sqrt{ } \mathrm{x}+1$

${ }^{2} \mathrm{~A}$ equação de regressão e seu respectivo coeficiente de determinação são relativos ao efeito de níveis de densidade dentro de cada tratamento.

${ }^{3}$ TEST, EPO e MPO são abreviações de Testemunha, pós-precoce e pós-mediana, respectivamente.

${ }^{4}$ Médias com letras iguais nas colunas não diferem entre si pelo teste de Tukey a 5\% de significância. As médias comparam o efeito dos tratamentos dentro de cada densidade. 
Tabela 13. Efeitos de densidades de $A$. rudis no número de plantas, colmos e panículas por metro, número de espiguetas e grãos formados por panícula, altura de plantas, comprimento de panículas e produção na cultura do arroz irrigado. Taubaté, SP, 2001

\begin{tabular}{|c|c|c|c|c|c|c|}
\hline \multirow{2}{*}{ Parâmetros avaliados } & \multicolumn{5}{|c|}{ Densidades de Aeschynomene rudis Benth. } & \multirow{2}{*}{$\begin{array}{c}\text { Equações de regressão polinomiais e } \\
\text { coef. de determinação }^{1}\end{array}$} \\
\hline & 0 & 3 & 6 & 12 & 24 & \\
\hline $\mathrm{N}^{\circ}$ plantas. $\mathrm{m}^{-1}$ & 259,75 & 255,75 & 269,25 & 250,50 & 255,75 & não significativo \\
\hline $\mathrm{N}^{\circ}$ Colmos.m ${ }^{-1}$ & 131,78 & 122,89 & 117,38 & 112,56 & 107,33 & $\hat{y}=11,251-0,042 x \quad r^{2}=84,80 \%$ \\
\hline Altura (cm) & 74,08 & 73,90 & 73,78 & 72,15 & 67,73 & não significativo \\
\hline $\mathrm{N}^{\circ}$ panículas.m $\mathrm{m}^{-1}$ & 130,23 & 119,64 & 107,78 & 107,71 & 92,56 & $\hat{y}=11,147-0,067 x \quad r^{2}=88,42 \%$ \\
\hline Comp. Panículas (cm) & 20,68 & 19,98 & 19,45 & 19,30 & 17,48 & $\hat{y}=20,459-0,120 x \quad r^{2}=92,04 \%$ \\
\hline $\mathrm{N}^{\circ}$ espiguetas.pan. ${ }^{-1}$ & 92,70 & 79,82 & 74,35 & 70,42 & 63,74 & $\hat{y}=9,242-0,059 x$ \\
\hline$N^{\circ}$ Grãos form.pan. ${ }^{-1}$ & 83,74 & 67,97 & 59,69 & 54,82 & 43,22 & $\hat{y}=8,674-0,095 x$ \\
\hline Produção (kg.ha-1) & 5822,5 & 4400,3 & 3807,5 & 3334,8 & 2474,8 & $\hat{y}=5045,5-119,73 x$ \\
\hline Índ. Colheita mecânica & 5,00 & 2,19 & 1,16 & 1,16 & 0,22 & $\hat{y}=2,061-0,045 x$ \\
\hline
\end{tabular}

${ }^{1}$ A equação de regressão e seu respectivo coeficiente de determinação são relativos ao efeito de níveis de densidade dentro do tratamento testemunha.

Tabela 14. Comparação entre épocas de aplicação do herbicida ethoxysulfuron no número de plantas, colmos e panículas por metro, número de espiguetas e grãos formados por panícula, altura de plantas, comprimento de panículas e produção na cultura do arroz irrigado. Taubaté, SP, 2001

\begin{tabular}{|c|c|c|c|c|c|c|c|c|c|}
\hline & $\begin{array}{c}\text { Núm. } \\
\text { Plantas }{ }^{1} \\
\text { m }^{-1}\end{array}$ & $\begin{array}{c}\text { Colmos }^{1} \\
\mathrm{~m}^{-1}\end{array}$ & $\begin{array}{c}\text { Altura }^{2} \\
\text { (cm) }\end{array}$ & $\begin{array}{c}\text { Núm. } \\
\text { Panículas }{ }^{1} \\
\text { m}^{-1}\end{array}$ & $\begin{array}{c}\text { Comp. } \\
\text { Panículas }^{2} \\
\text { (cm) }\end{array}$ & $\begin{array}{c}\text { Núm. } \\
\text { Espiguetas }^{1} \\
\text { Panicula }^{-1}\end{array}$ & $\begin{array}{l}\text { Núm. grãos } \\
\text { Formados }^{1} \\
\text { panicula }^{-1}\end{array}$ & $\begin{array}{c}\text { Produção }{ }^{2} \\
\text { kg.ha }{ }^{-1}\end{array}$ & $\begin{array}{c}\text { Índice }^{3} \\
\text { Colheita } \\
\text { Mecânica }\end{array}$ \\
\hline TEST. $^{4}$ & $85,00 a^{5}$ & $114,97 \mathrm{~b}$ & 71,96 a & $106,72 \mathrm{~b}$ & $19,05 \mathrm{~b}$ & $71,96 \mathrm{~b}$ & $56,06 \mathrm{~b}$ & $3504,3 \mathrm{~b}$ & $1,12 \mathrm{~b}$ \\
\hline EPO & $90,00 \mathrm{a}$ & 132,34 a & 73,83 a & 130,24 a & 20,68 a & $94,00 \mathrm{a}$ & 84,65 a & 5886,6 a & $5,00 \mathrm{a}$ \\
\hline MPO & 89,75 a & 130,70 a & $72,47 \mathrm{a}$ & 126,16 a & 20,83 a & $92,58 \mathrm{a}$ & 82,97 a & 5687,8 a & 4,73 a \\
\hline CV(\%) & 5,04 & 2,96 & 4,88 & 2,75 & 3,00 & 2,47 & 4,33 & 4,80 & 8,49 \\
\hline
\end{tabular}

${ }^{1}$ Dados transformados em $\sqrt{ } \mathrm{x}$.

${ }^{2}$ Dados não transformados.

${ }^{3}$ Dados transformados em $\sqrt{\mathrm{X}}+1$

${ }^{4}$ TEST, EPO e MPO são abreviações de Testemunha, pós-precoce e pós-mediana, respectivamente.

${ }^{5}$ Médias seguidas por letras iguais, nas colunas, não diferem entre si pelo teste de Tukey a 5\% de significância. As médias comparam o efeito dos tratamentos dentro de cada densidade. 
Tabela 15. Fitointoxicação do herbicida ethoxysulfuron em duas épocas de aplicação à cultura do arroz irrigado. Taubaté, SP, 2001

\begin{tabular}{|c|c|c|c|c|c|c|c|c|}
\hline & \multirow{2}{*}{$\begin{array}{l}\text { Dose } \\
\text { g.ha-1 }\end{array}$} & \multicolumn{2}{|c|}{ A. rudis } & \multicolumn{5}{|c|}{ \% Fitointoxicação à cultura ${ }^{1}$ - DAB } \\
\hline & & pl.m ${ }^{-2}$ & Estádio & 09 & 17 & 58 & 93 & 108 \\
\hline 1. Testemunha & & 0 & - & $0,0 a^{2}$ & $0,0 \mathrm{a}$ & $0,0 \mathrm{a}$ & $0,0 \mathrm{a}$ & $0,0 \mathrm{a}$ \\
\hline 2. Testemunha & & 3 & - & $0,0 \mathrm{a}$ & $0,0 \mathrm{a}$ & $0,0 \mathrm{a}$ & $0,0 \mathrm{a}$ & $0,0 \mathrm{a}$ \\
\hline 3. Testemunha & & 6 & - & $0,0 \mathrm{a}$ & $0,0 \mathrm{a}$ & $0,0 \mathrm{a}$ & $0,0 \mathrm{a}$ & $0,0 \mathrm{a}$ \\
\hline 4. Testemunha & & 12 & - & $0,0 \mathrm{a}$ & $0,0 \mathrm{a}$ & $0,0 \mathrm{a}$ & $0,0 \mathrm{a}$ & $0,0 \mathrm{a}$ \\
\hline 5. Testemunha & & 24 & - & $0,0 \mathrm{a}$ & $0,0 \mathrm{a}$ & $0,0 \mathrm{a}$ & $0,0 \mathrm{a}$ & $0,0 \mathrm{a}$ \\
\hline 6. Ethoxysulfuron ${ }^{3}+$ adj. $^{4}$ & $80+0,3 \%$ & 3 & 4 folhas & $0,0 \mathrm{a}$ & $0,0 \mathrm{a}$ & $0,0 \mathrm{a}$ & $0,0 \mathrm{a}$ & $0,0 \mathrm{a}$ \\
\hline 7. Ethoxysulfuron ${ }^{3}+$ adj. $^{4}$ & $80+0,3 \%$ & 6 & 4 folhas & $0,0 \mathrm{a}$ & $0,0 \mathrm{a}$ & $0,0 \mathrm{a}$ & $0,0 \mathrm{a}$ & $0,0 \mathrm{a}$ \\
\hline 8. Ethoxysulfuron ${ }^{3}+$ adj. $^{4}$ & $80+0,3 \%$ & 12 & 4 folhas & $0,0 \mathrm{a}$ & $0,0 \mathrm{a}$ & $0,0 \mathrm{a}$ & 0,0 a & $0,0 \mathrm{a}$ \\
\hline 9. Ethoxysulfuron ${ }^{3}+$ adj. $^{4}$ & $80+0,3 \%$ & 24 & 4 folhas & 0,0 a & $0,0 \mathrm{a}$ & $0,0 \mathrm{a}$ & $0,0 \mathrm{a}$ & $0,0 \mathrm{a}$ \\
\hline 10. Ethoxysulfuron ${ }^{3}+$ adj. $^{4}$ & $80+0,3 \%$ & 3 & 6 folhas & $0,0 \mathrm{a}$ & $0,0 \mathrm{a}$ & $0,0 \mathrm{a}$ & 0,0 a & $0,0 \mathrm{a}$ \\
\hline 11. Ethoxysulfuron ${ }^{3}+$ adj. $^{4}$ & $80+0,3 \%$ & 6 & 6 folhas & $0,0 \mathrm{a}$ & $0,0 \mathrm{a}$ & $0,0 \mathrm{a}$ & $0,0 \mathrm{a}$ & $0,0 \mathrm{a}$ \\
\hline 12. Ethoxysulfuron ${ }^{3}+$ adj. $^{4}$ & $80+0,3 \%$ & 12 & 6 folhas & $0,0 \mathrm{a}$ & $0,0 \mathrm{a}$ & $0,0 \mathrm{a}$ & 0,0 a & $0,0 \mathrm{a}$ \\
\hline 13. Ethoxysulfuron ${ }^{3}+$ adj. $^{4}$ & $80+0,3 \%$ & 24 & 6 folhas & $0,0 \mathrm{a}$ & $0,0 \mathrm{a}$ & $0,0 \mathrm{a}$ & $0,0 \mathrm{a}$ & $0,0 \mathrm{a}$ \\
\hline CV(\%) & & & & 0,00 & 0,00 & 0,00 & 0,00 & 0,00 \\
\hline
\end{tabular}

${ }^{1}$ Dados transformados em arc sen $\sqrt{ }$

${ }^{2}$ Médias com letras iguais nas colunas não diferem entre si pelo teste de Tukey a 5\% de significância

${ }^{3}$ Gladium (ethoxysulfuron 600 g. $\mathrm{kg}^{-1}$ )

${ }^{4}$ Hoefix (lauril éter sulfato de sódio 279 g.L ${ }^{-1}$ ). 
Tabela 16. Eficácia do herbicida ethoxysulfuron no controle de diferentes densidades de A. rudis, em duas épocas de aplicação, na cultura do arroz irrigado. Taubaté, SP, 2001

\begin{tabular}{|c|c|c|c|c|c|c|c|c|}
\hline & \multirow{2}{*}{$\begin{array}{l}\text { Dose } \\
\text { g.ha }{ }^{-1}\end{array}$} & \multicolumn{2}{|c|}{ A. rudis } & \multicolumn{5}{|c|}{ \% Controle de $A$. rudis $^{1}$ - DAB } \\
\hline & & pl.m ${ }^{-2}$ & Estádio & 09 & 17 & 58 & 93 & 108 \\
\hline 1. Testemunha & & 0 & - & $100,0 \mathrm{a}^{2}$ & 100,0 a & 100,0 a & 100,0 a & $100,0 \mathrm{a}$ \\
\hline 2. Testemunha & & 3 & - & $0,0 \mathrm{~d}$ & $0,0 \mathrm{c}$ & $0,0 \mathrm{c}$ & 0,0 c & $0,0 \mathrm{c}$ \\
\hline 3. Testemunha & & 6 & - & $0,0 \mathrm{~d}$ & $0,0 \mathrm{c}$ & $0,0 \mathrm{c}$ & $0,0 \mathrm{c}$ & $0,0 \mathrm{c}$ \\
\hline 4. Testemunha & & 12 & - & $0,0 \mathrm{~d}$ & $0,0 \mathrm{c}$ & $0,0 \mathrm{c}$ & $0,0 \mathrm{c}$ & $0,0 \mathrm{c}$ \\
\hline 5. Testemunha & & 24 & - & $0,0 \mathrm{~d}$ & $0,0 \mathrm{c}$ & $0,0 \mathrm{c}$ & $0,0 \mathrm{c}$ & $0,0 \mathrm{c}$ \\
\hline 6. Ethoxysulfuron ${ }^{3}+$ adj. $^{4}$ & $80+0,3 \%$ & 3 & 4 folhas & $98,3 \mathrm{~b}$ & 100,0 a & 100,0 a & 100,0 a & 99,9 a \\
\hline 7. Ethoxysulfuron ${ }^{3}+$ adj. $^{4}$ & $80+0,3 \%$ & 6 & 4 folhas & $98,3 \mathrm{~b}$ & 100,0 a & 100,0 a & $100,0 \mathrm{a}$ & 99,6 a \\
\hline 8. Ethoxysulfuron ${ }^{3}+$ adj. $^{4}$ & $80+0,3 \%$ & 12 & 4 folhas & $98,1 \mathrm{~b}$ & 100,0 a & 100,0 a & 99,9 a & 99,6 a \\
\hline 9. Ethoxysulfuron ${ }^{3}+$ adj. $^{4}$ & $80+0,3 \%$ & 24 & 4 folhas & $95,8 \mathrm{~b}$ & 100,0 a & 99,7 a & 99,7 a & $99,1 \mathrm{a}$ \\
\hline 10. Ethoxysulfuron ${ }^{3}+$ adj. $^{4}$ & $80+0,3 \%$ & 3 & 6 folhas & 85,5 c & $98,2 \mathrm{~b}$ & $98,1 \mathrm{~b}$ & $96,6 \mathrm{~b}$ & $95,4 \mathrm{~b}$ \\
\hline 11. Ethoxysulfuron ${ }^{3}+$ adj. $^{4}$ & $80+0,3 \%$ & 6 & 6 folhas & 85,5 c & $97,4 \mathrm{~b}$ & $97,5 \mathrm{~b}$ & $96,1 \mathrm{~b}$ & $95,4 \mathrm{~b}$ \\
\hline 12. Ethoxysulfuron ${ }^{3}+$ adj. $^{4}$ & $80+0,3 \%$ & 12 & 6 folhas & $83,8 \mathrm{c}$ & $96,5 \mathrm{~b}$ & $97,4 \mathrm{~b}$ & $96,3 \mathrm{~b}$ & $95,1 \mathrm{~b}$ \\
\hline 13. Ethoxysulfuron ${ }^{3}+$ adj. $^{4}$ & $80+0,3 \%$ & 24 & 6 folhas & $82,6 \mathrm{c}$ & $96,5 \mathrm{~b}$ & $96,8 \mathrm{~b}$ & $95,8 \mathrm{~b}$ & $94,6 \mathrm{~b}$ \\
\hline CV(\%) & & & & 3,34 & 2,18 & 2,05 & 2,80 & 4,84 \\
\hline
\end{tabular}

${ }^{1}$ Dados transformados em arc sen $\sqrt{ }$

${ }^{2}$ Médias com letras iguais nas colunas não diferem entre si pelo teste de Tukey a 5\% de significância

${ }^{3}$ Gladium (ethoxysulfuron 600 g.kg ${ }^{-1}$ )

${ }^{4}$ Hoefix (lauril éter sulfato de sódio 279 g.L ${ }^{-1}$ ). 


\section{CONCLUSÕES}

a) Densidades de 3, 6, 12 e 24 plantas de $A$. rudis por metro quadrado, influenciam negativamente de forma linear, o número de colmos e panículas por metro, o comprimento das panículas, o número de espiguetas e grãos formados por panícula, o rendimento de grãos e o índice para colheita mecânica e não afetam o número de plantas por metro e a altura das plantas de arroz.

b) O herbicida ethoxysulfuron é eficiente no controle de $A$. rudis nos estádios de 4 e de 6 folhas, nas densidades de 3, 6, 12 e 24 plantas por metro quadrado.

c) Ethoxysulfuron na dose de 80 g.ha- ${ }^{-1}$, quando aplicado em pós-emergência precoce e mediana em densidades de 3, 6, 12 e 24 plantas de A. rudis por metro quadrado é seletivo para o cultivar de arroz Epagri 109, não interferindo nas seguintes variáveis: número de plantas, colmos e panículas por metro, alturas das plantas, comprimento das panículas, número de espiguetas e grãos formados por panícula, índice para colheita mecânica e rendimento de grãos. 
ANEXOS 


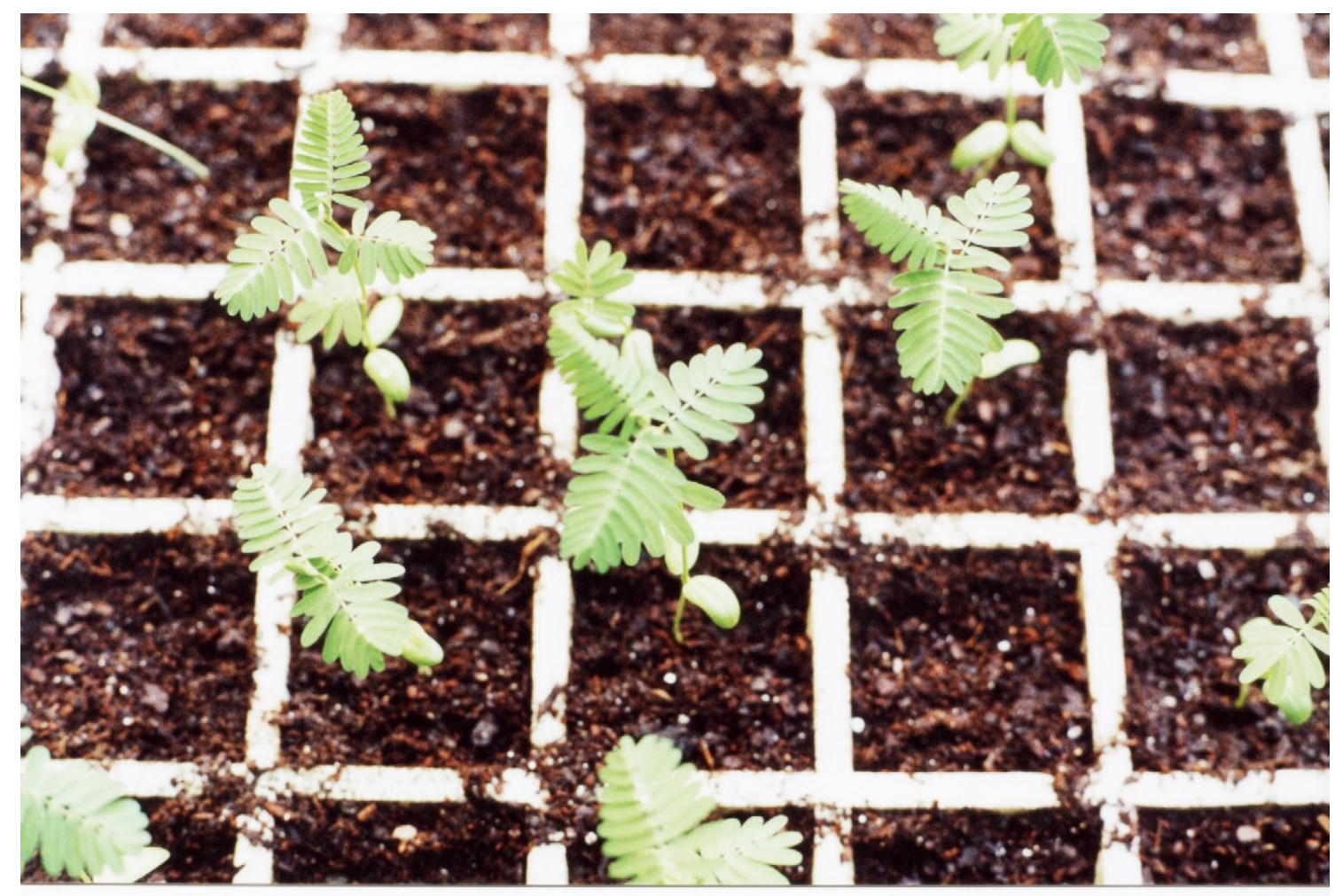

Anexo 1 - Teste de germinação de $A$. rudis em bandeja.

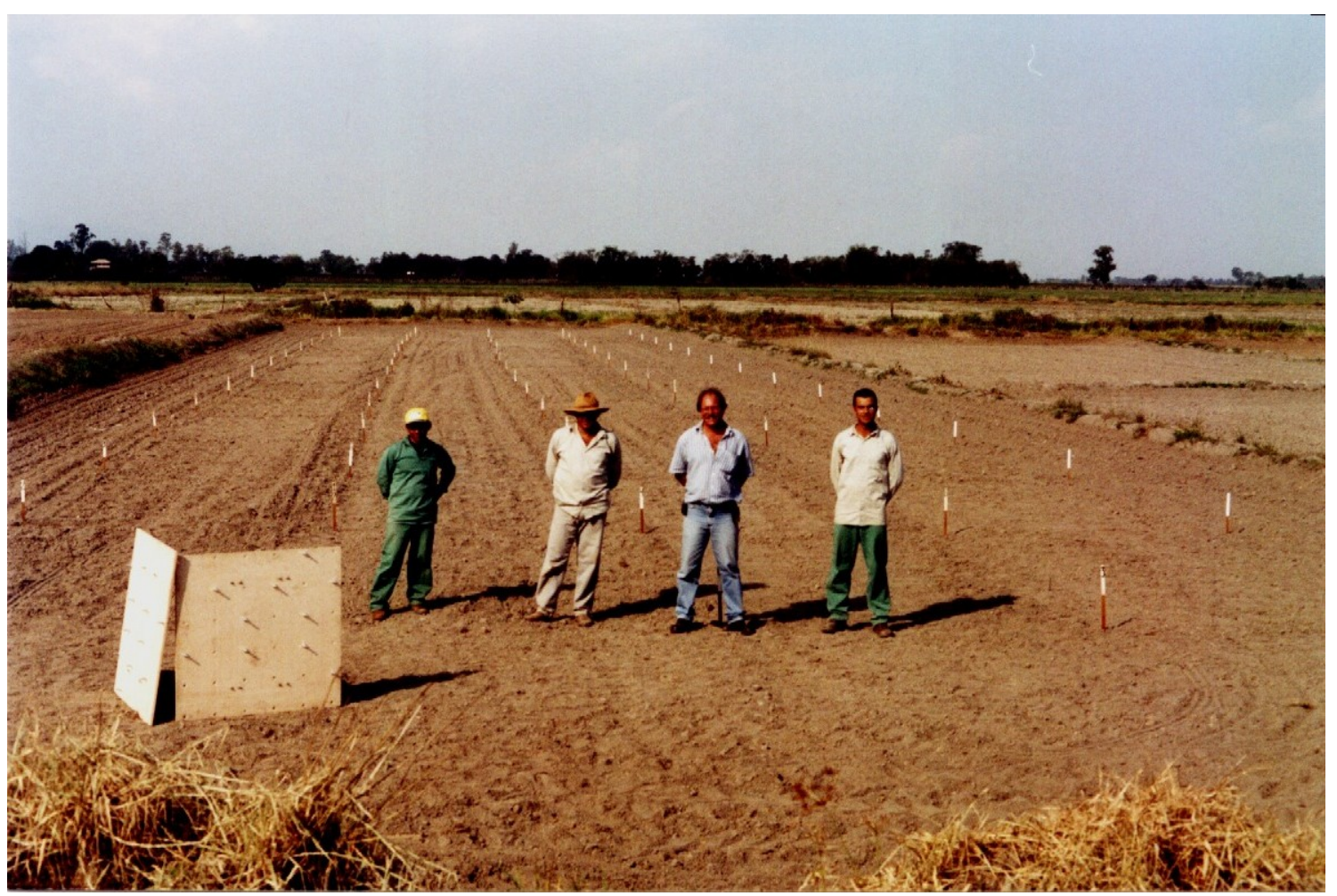

Anexo 2 - Vista geral da área no dia do plantio. 


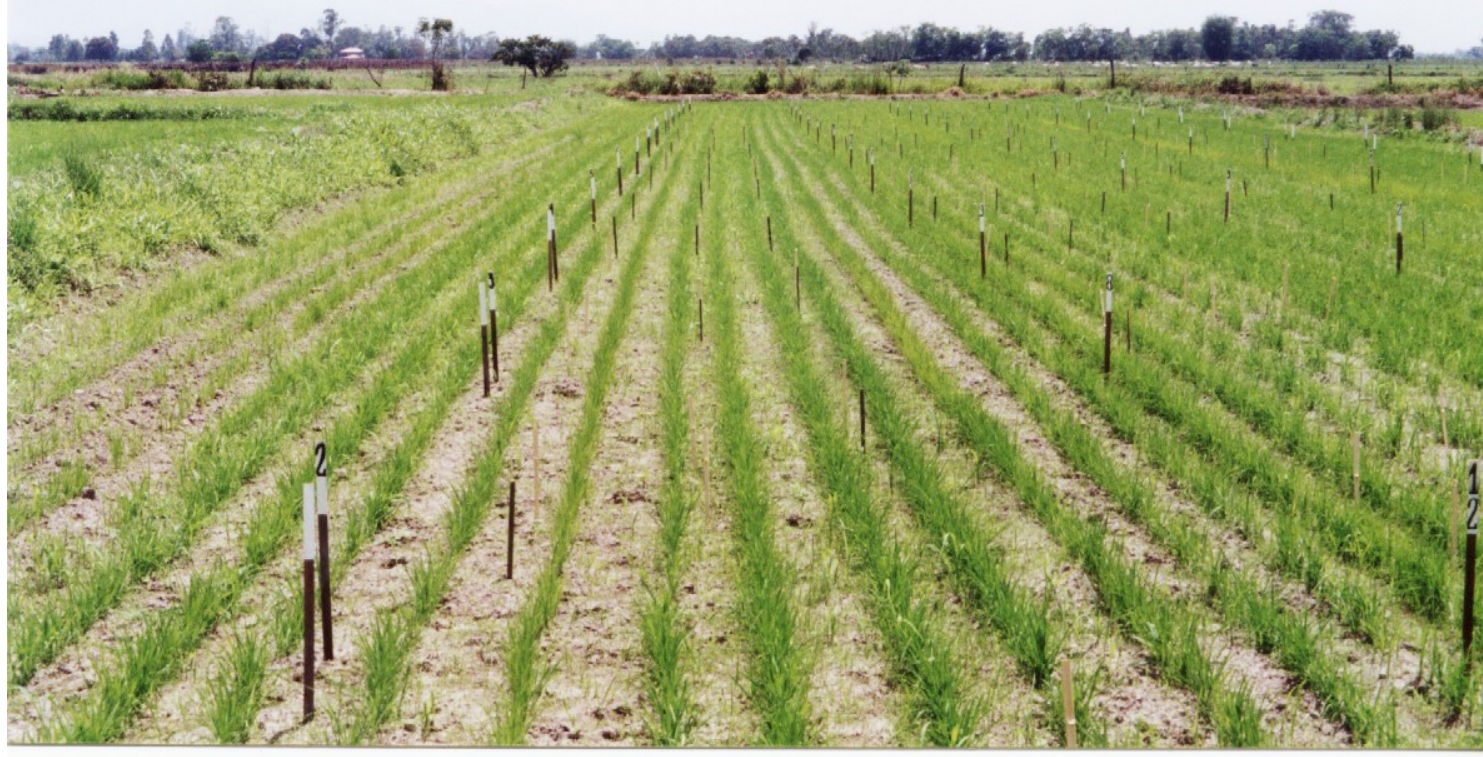

Anexo 3 - Vista geral no início do experimento.

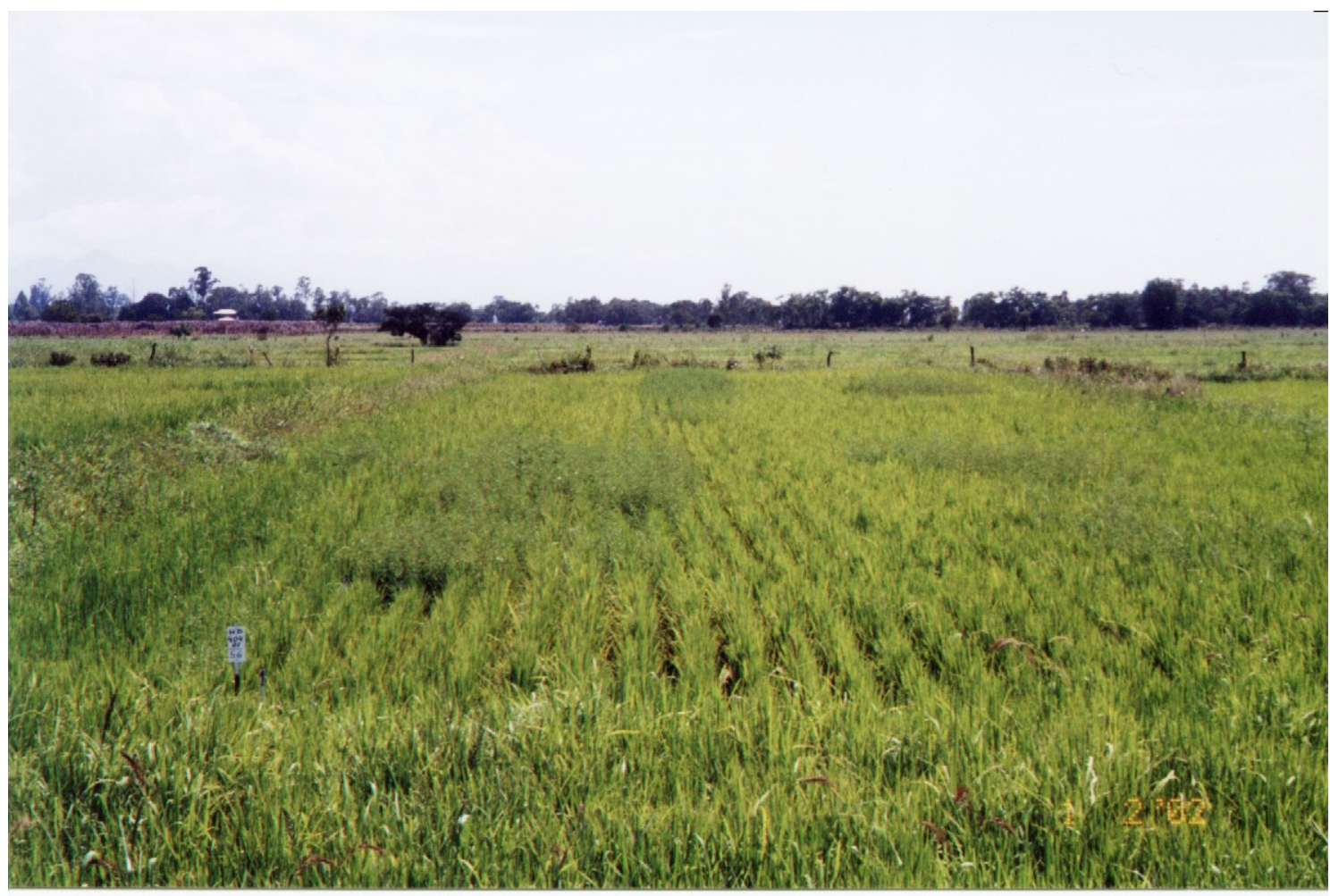

Anexo 4 - Vista geral do experimento 60 DAA. 


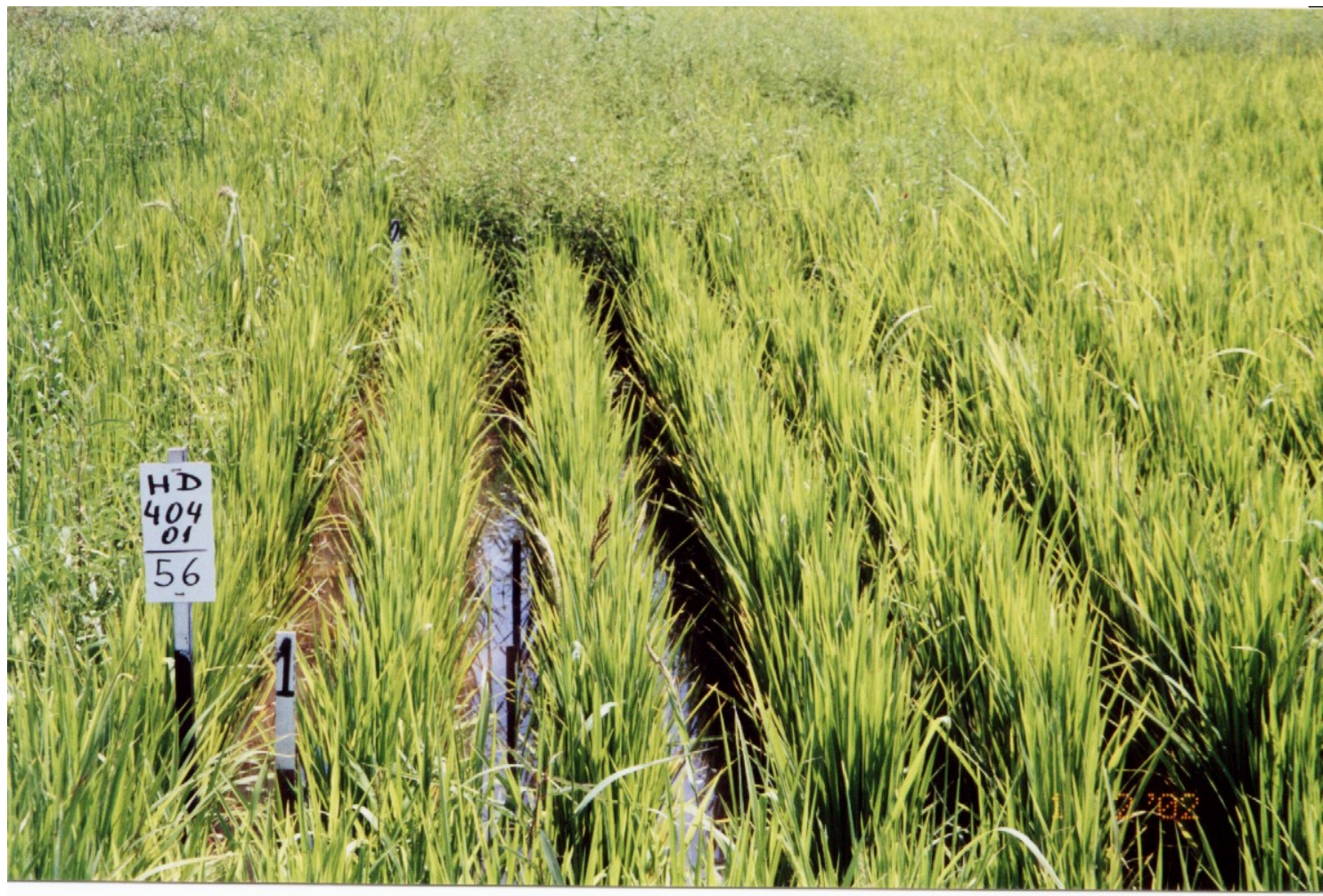

Anexo 5 - Testemunha capinada 60 DAA.

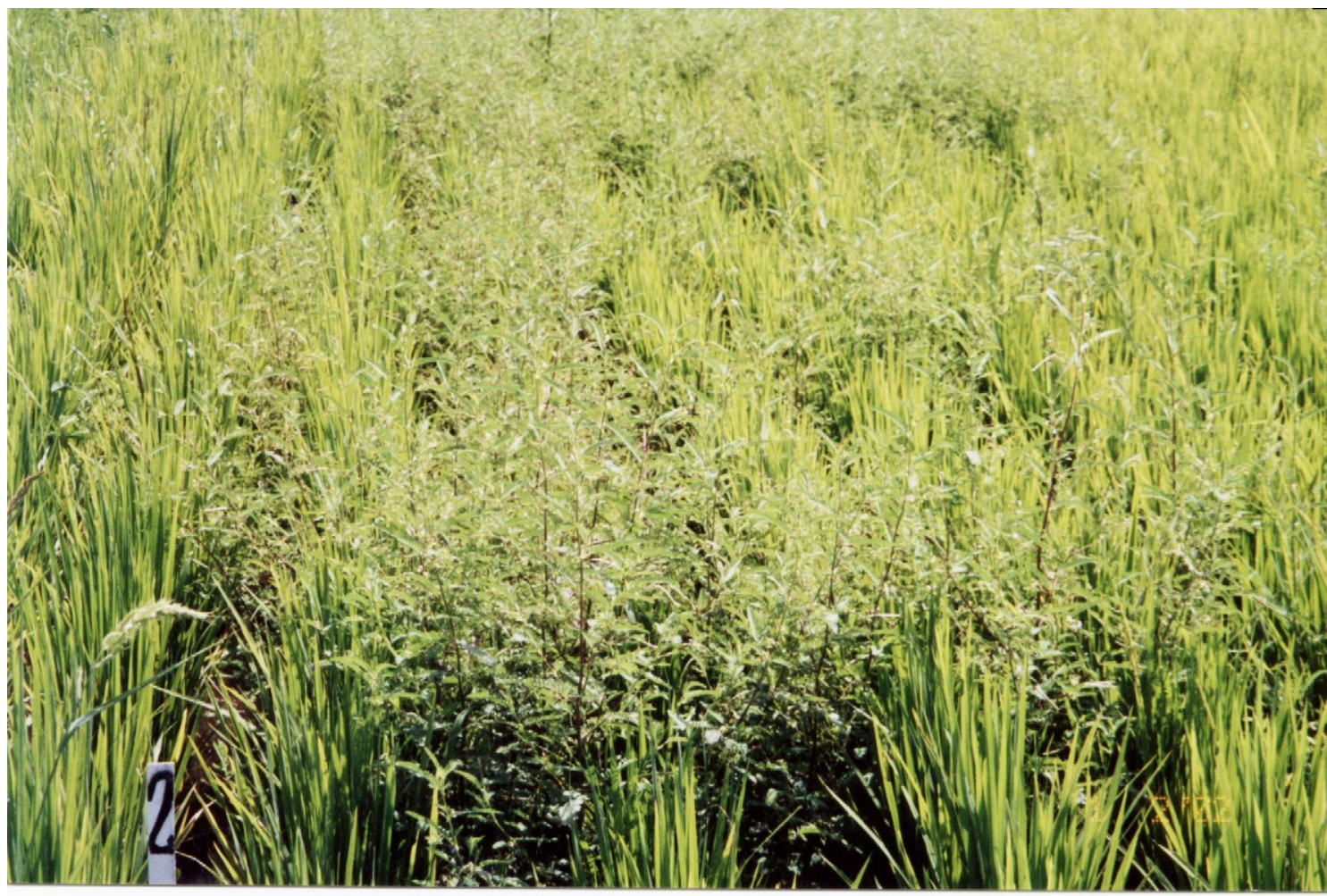

Anexo 6 - Densidade de 3 pl.m ${ }^{-2}$ de $A$. rudis 60 DAA 


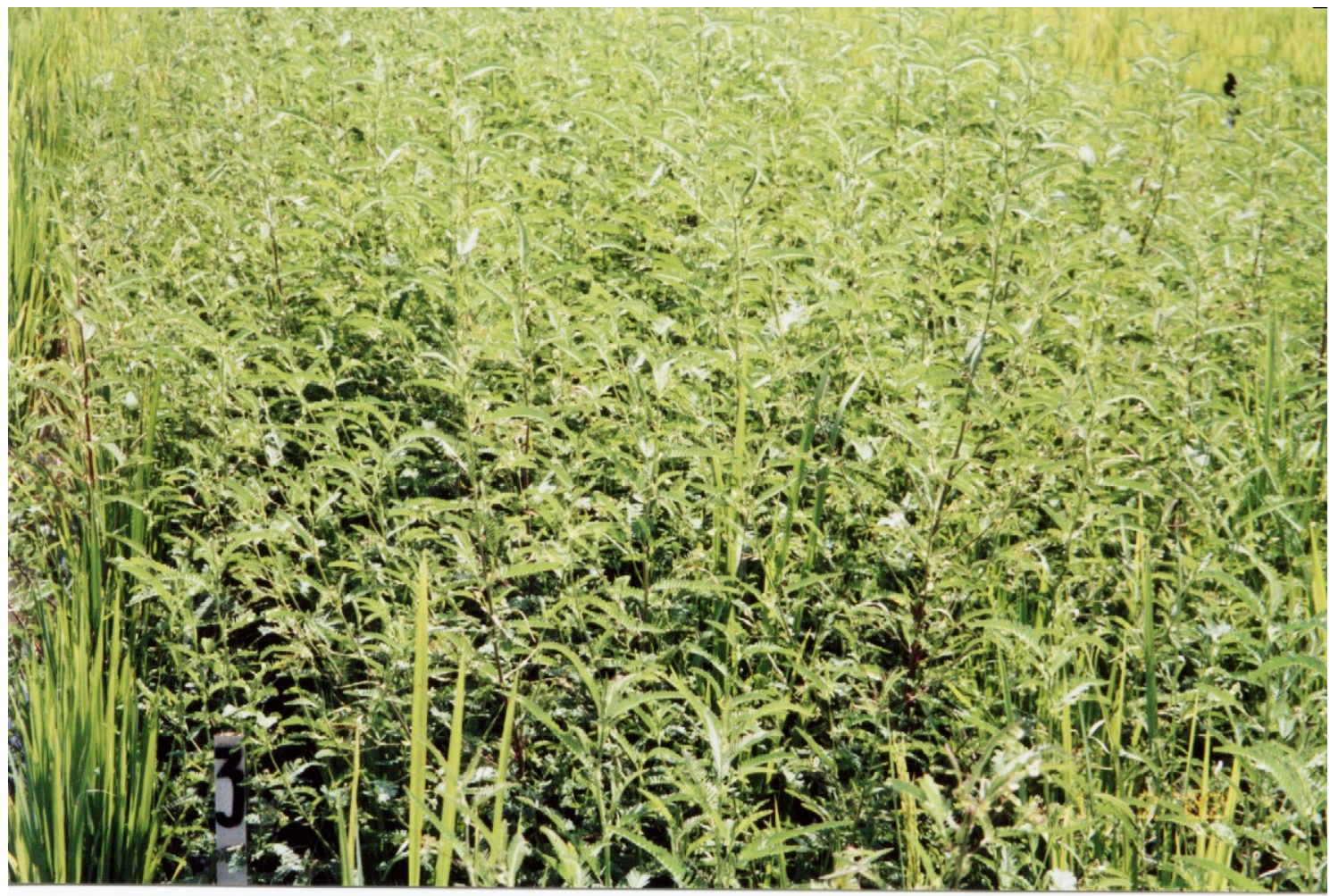

Anexo 7 - Densidade de 6 pl.m ${ }^{-2}$ de $A$. rudis 60 DAA.

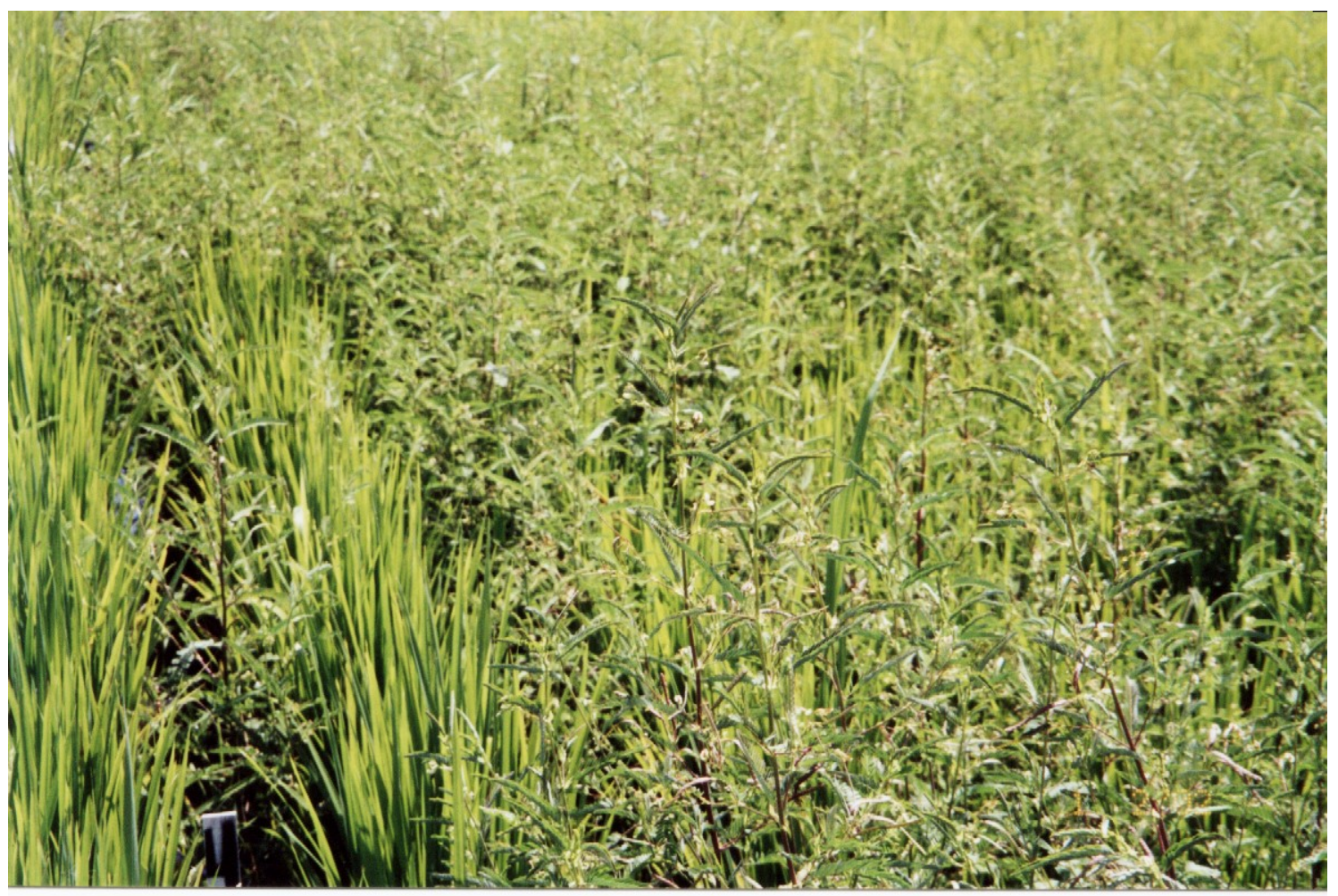

Anexo 8 - Densidade de $12 \mathrm{pl} \cdot \mathrm{m}^{-2}$ de $A$. rudis 60 DAA. 


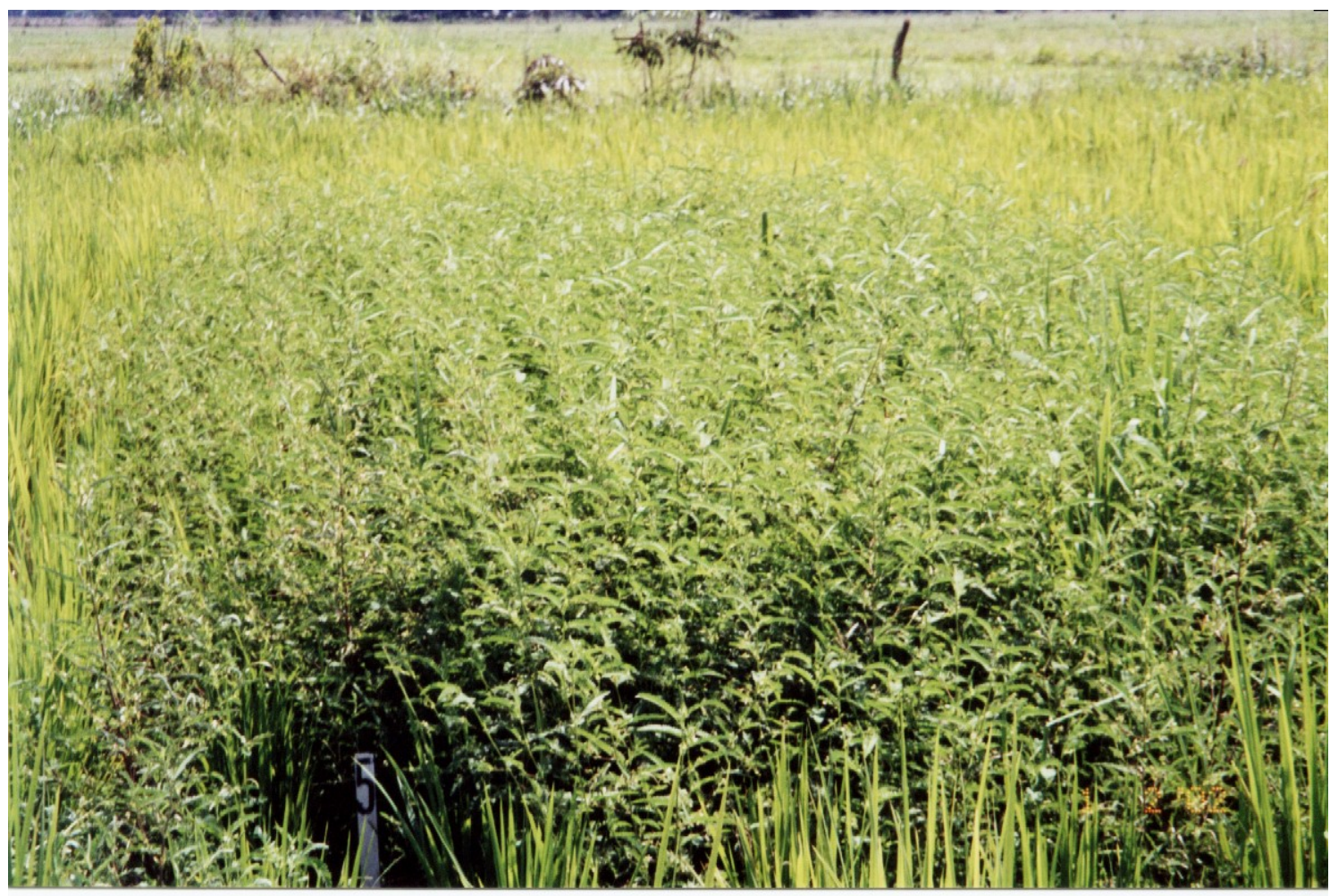

Anexo 9 - Densidade de 24 pl.m ${ }^{-2}$ de $A$. rudis 60 DAA.

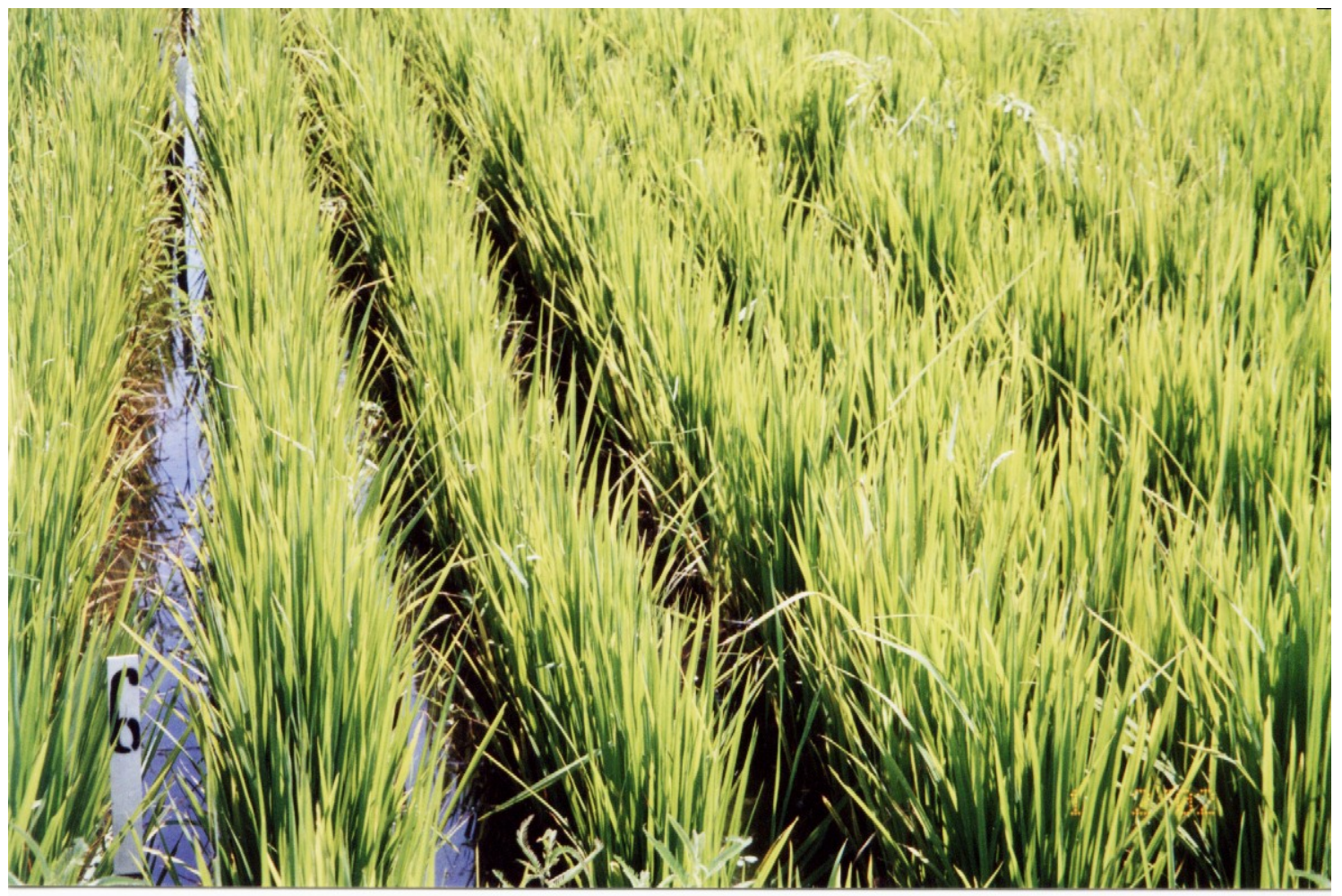

Anexo 10 - Ethoxysulfuron 80 g.ha ${ }^{-1}$ x 3 pl.m ${ }^{-2}$ de $A$. rudis 60 DAA, EPO. 


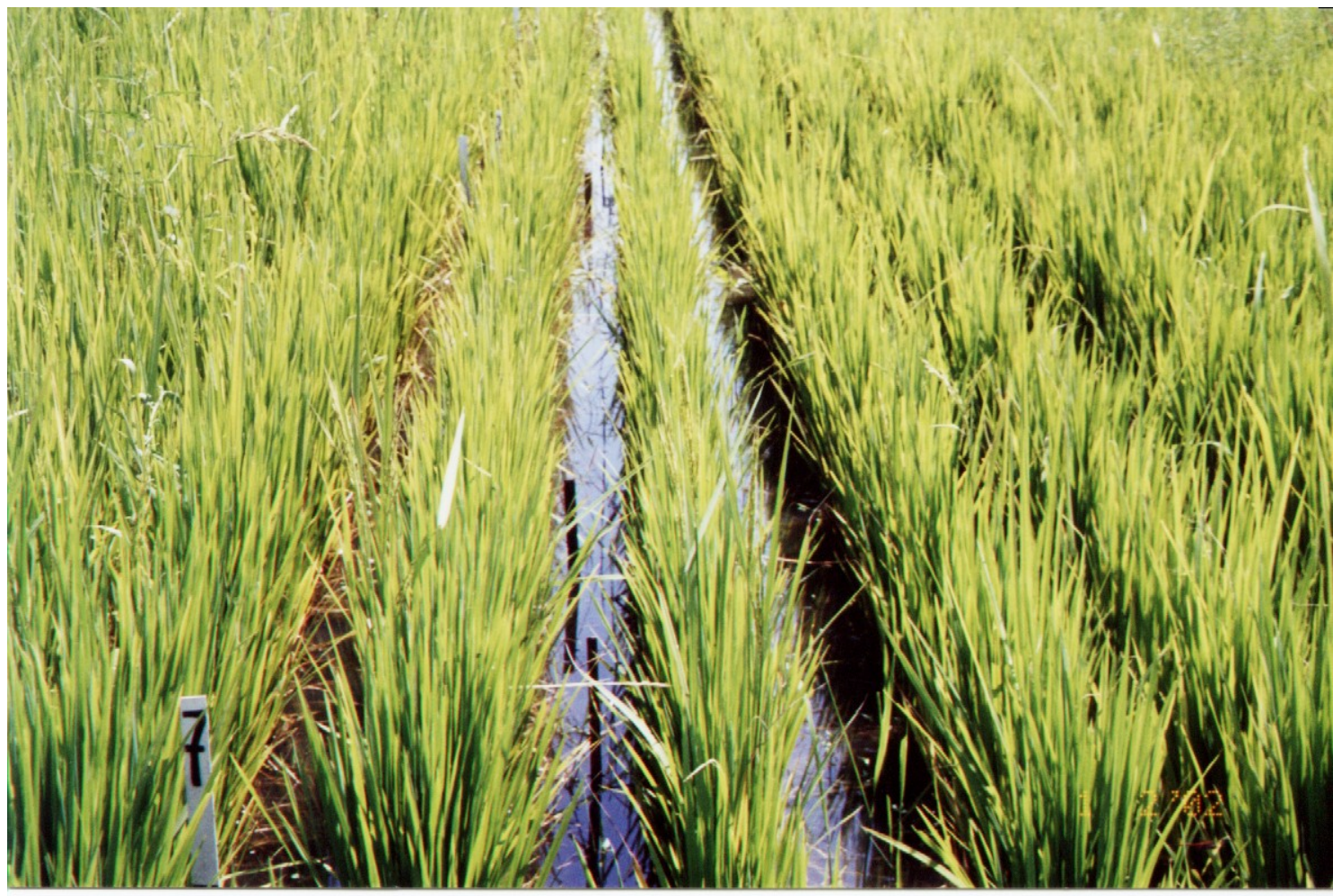

Anexo 11 - Ethoxysulfuron 80 g.ha ${ }^{-1}$ x 6 pl.m ${ }^{-2}$ de $A$. rudis 60 DAA, EPO.

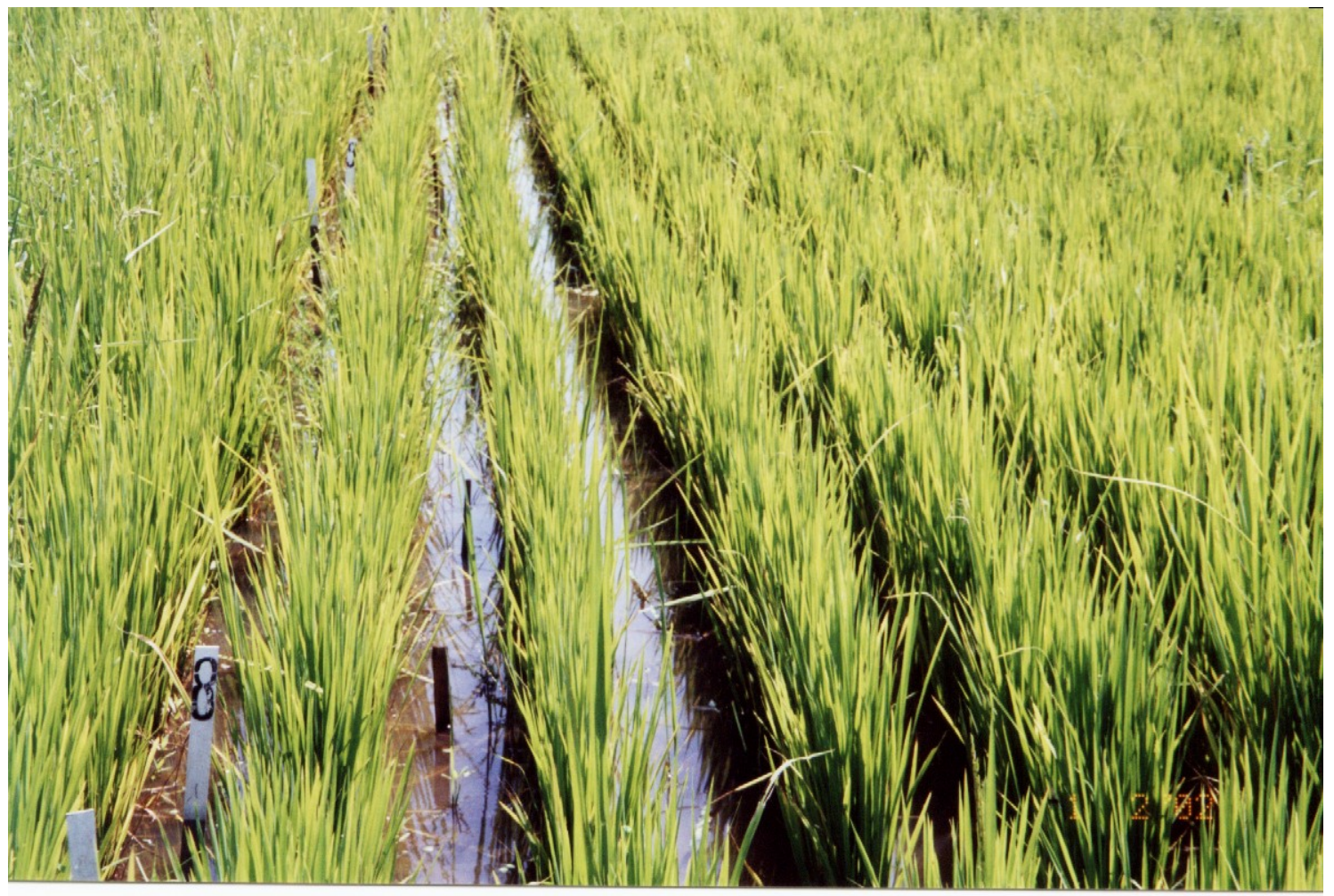

Anexo 12 - Ethoxysulfuron 80 g.ha $^{-1}$ x 12 pl.m ${ }^{-2}$ de A. rudis 60 DAA, EPO. 


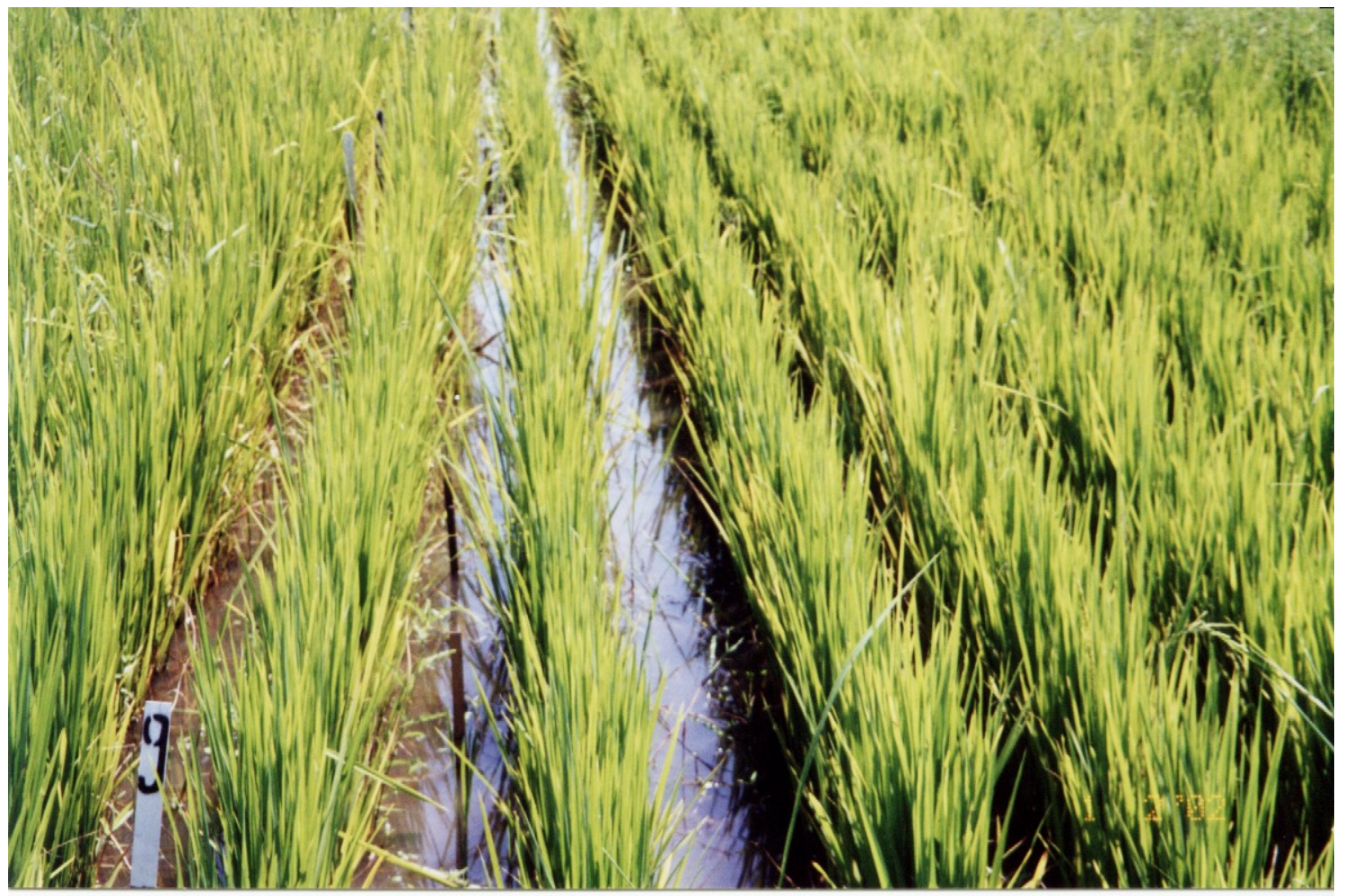

Anexo 13 - Ethoxysulfuron 80 g.ha $^{-1}$ x 24 pl.m ${ }^{-2}$ de A. rudis 60 DAA, EPO.

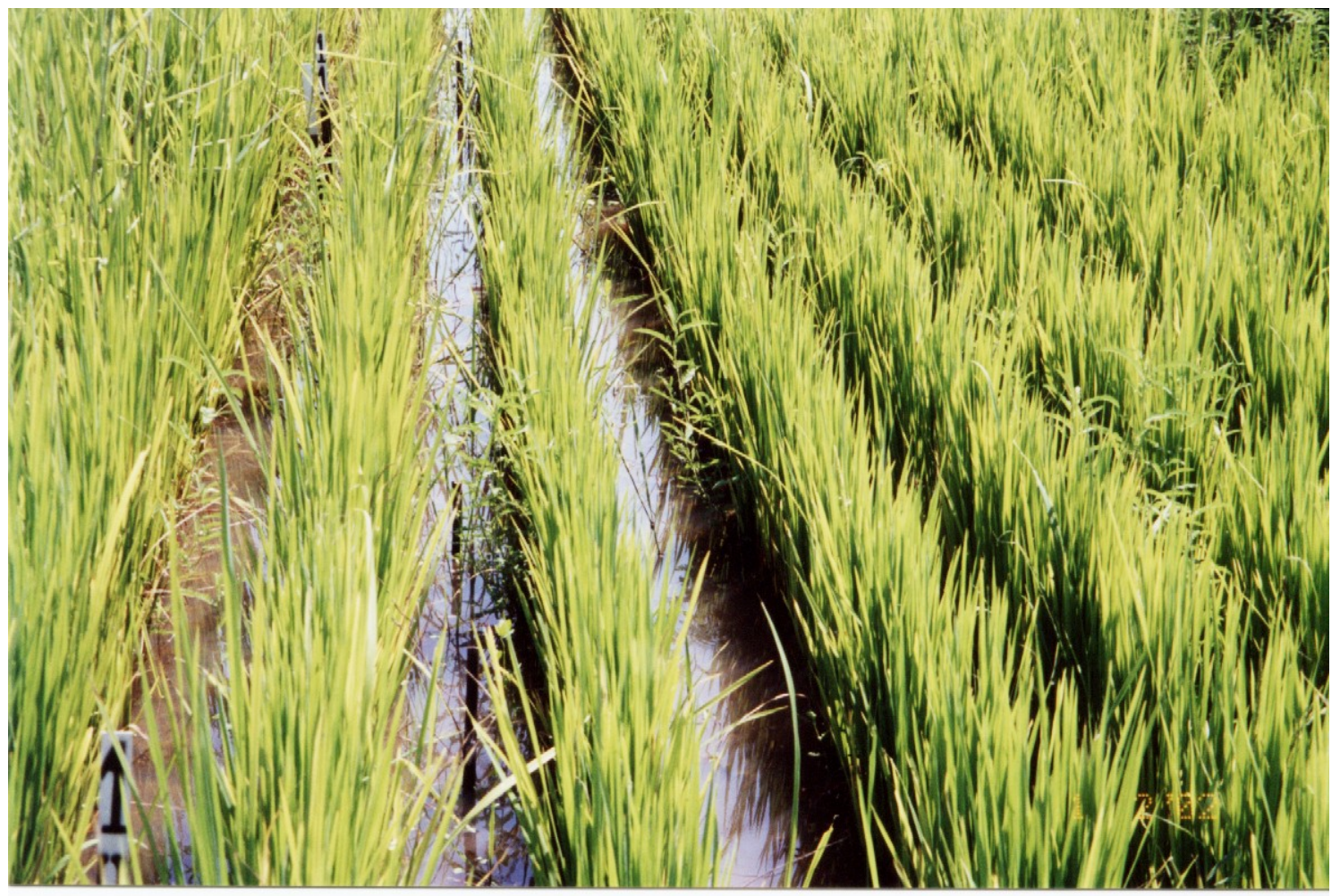

Anexo 14 - Ethoxysulfuron 80 g.ha ${ }^{-1}$ x 3 pl.m ${ }^{-2}$ de A. rudis 60 DAA, MPO. 


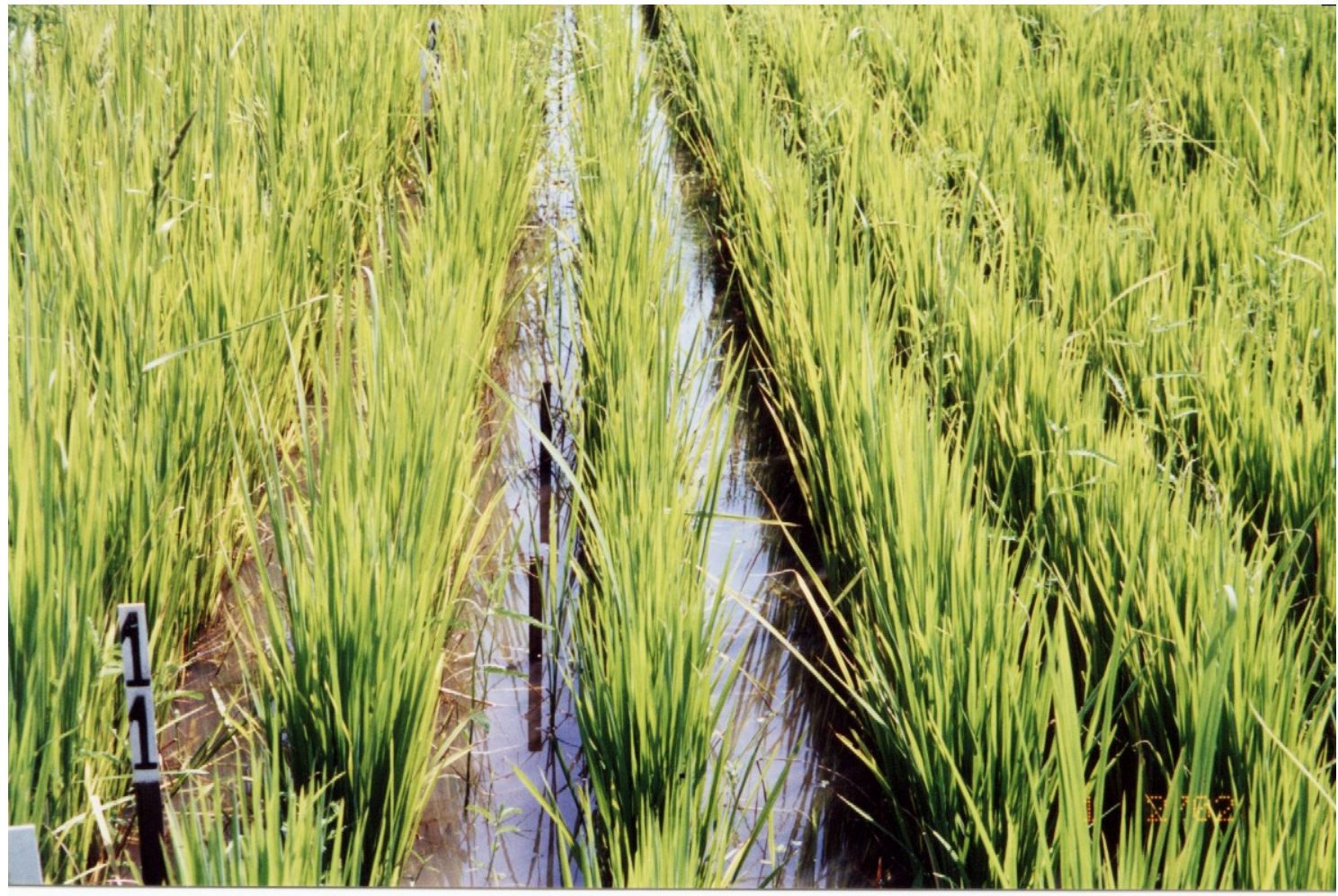

Anexo 15 - Ethoxysulfuron 80 g.ha ${ }^{-1}$ x 6 pl.m ${ }^{-2}$ de A. rudis 60 DAA, MPO.



Anexo 16 - Ethoxysulfuron 80 g.ha $^{-1}$ x 12 pl.m ${ }^{-2}$ de A. rudis 60 DAA, MPO. 


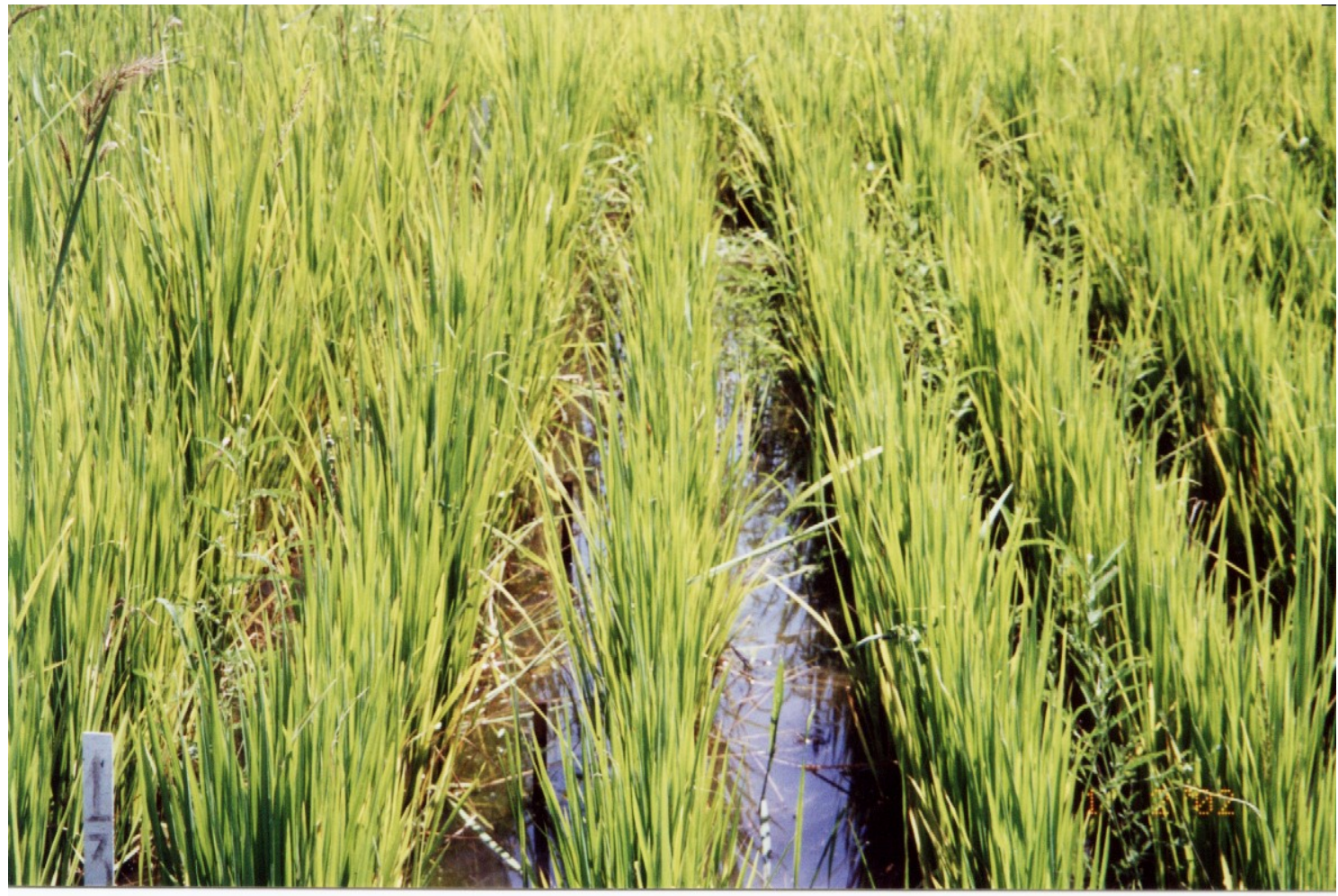

Anexo 17 - Ethoxysulfuron 80 g.ha ${ }^{-1}$ x 24 pl.m ${ }^{-2}$ de A. rudis 60 DAA, MPO.

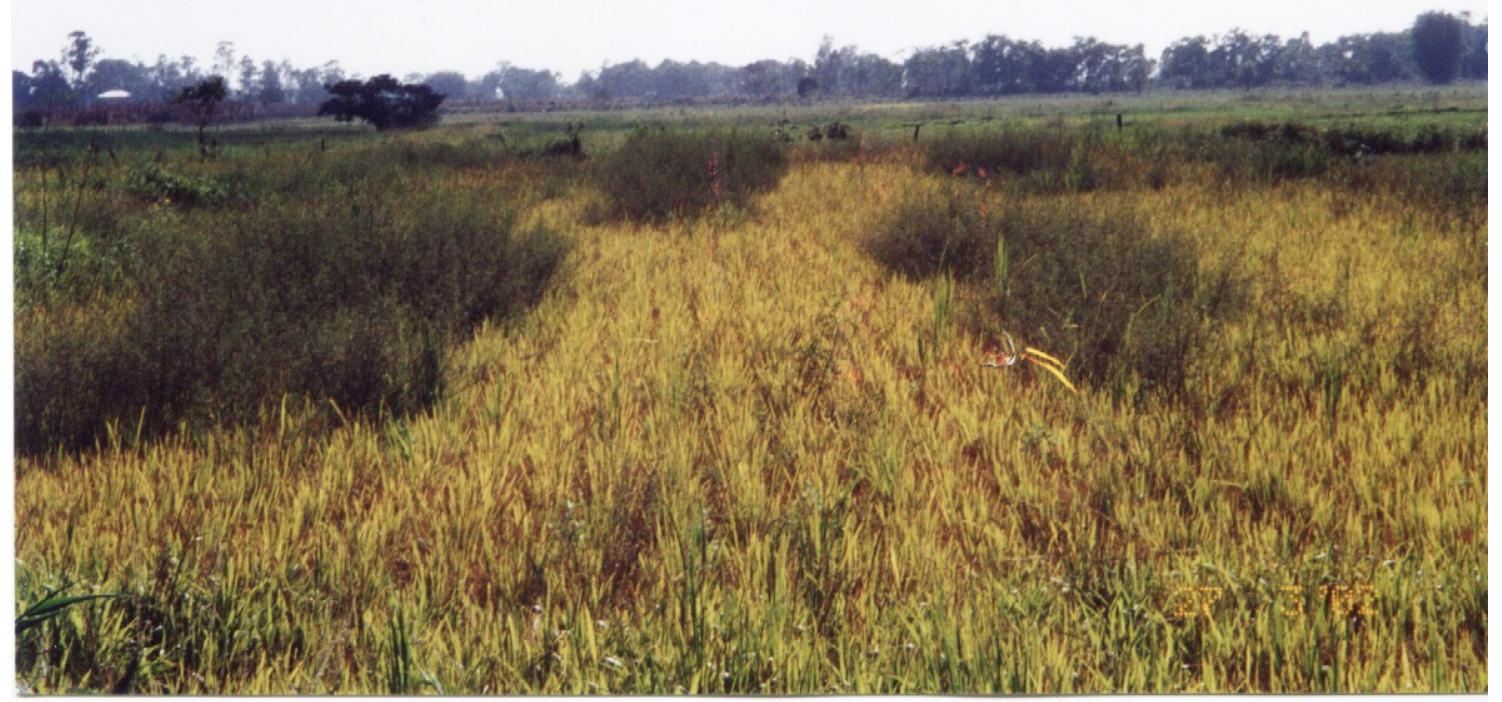

Anexo 18 - Vista geral do experimento no momento da colheita. 


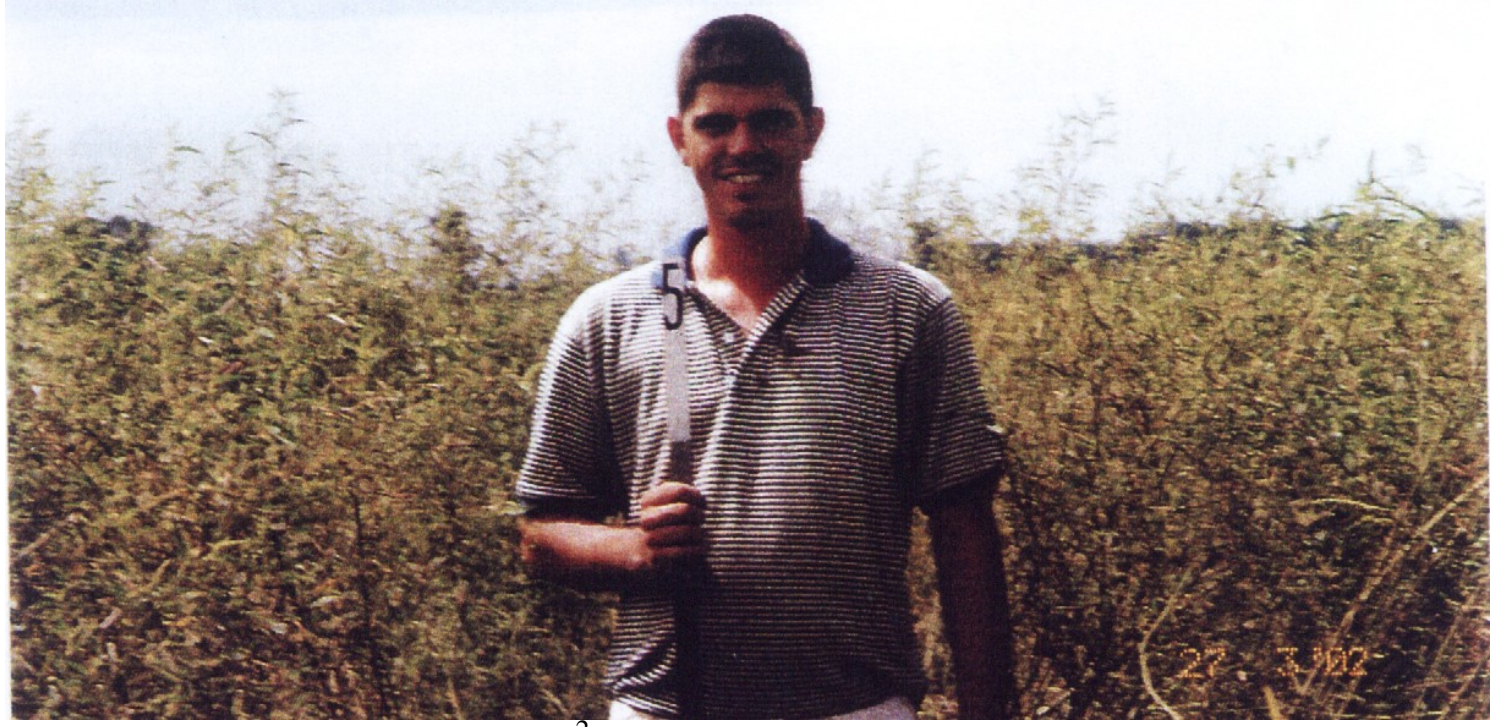

Anexo 19 - Densidade de 24 pl.m ${ }^{-2}$ de $A$. rudis no momento da colheita.

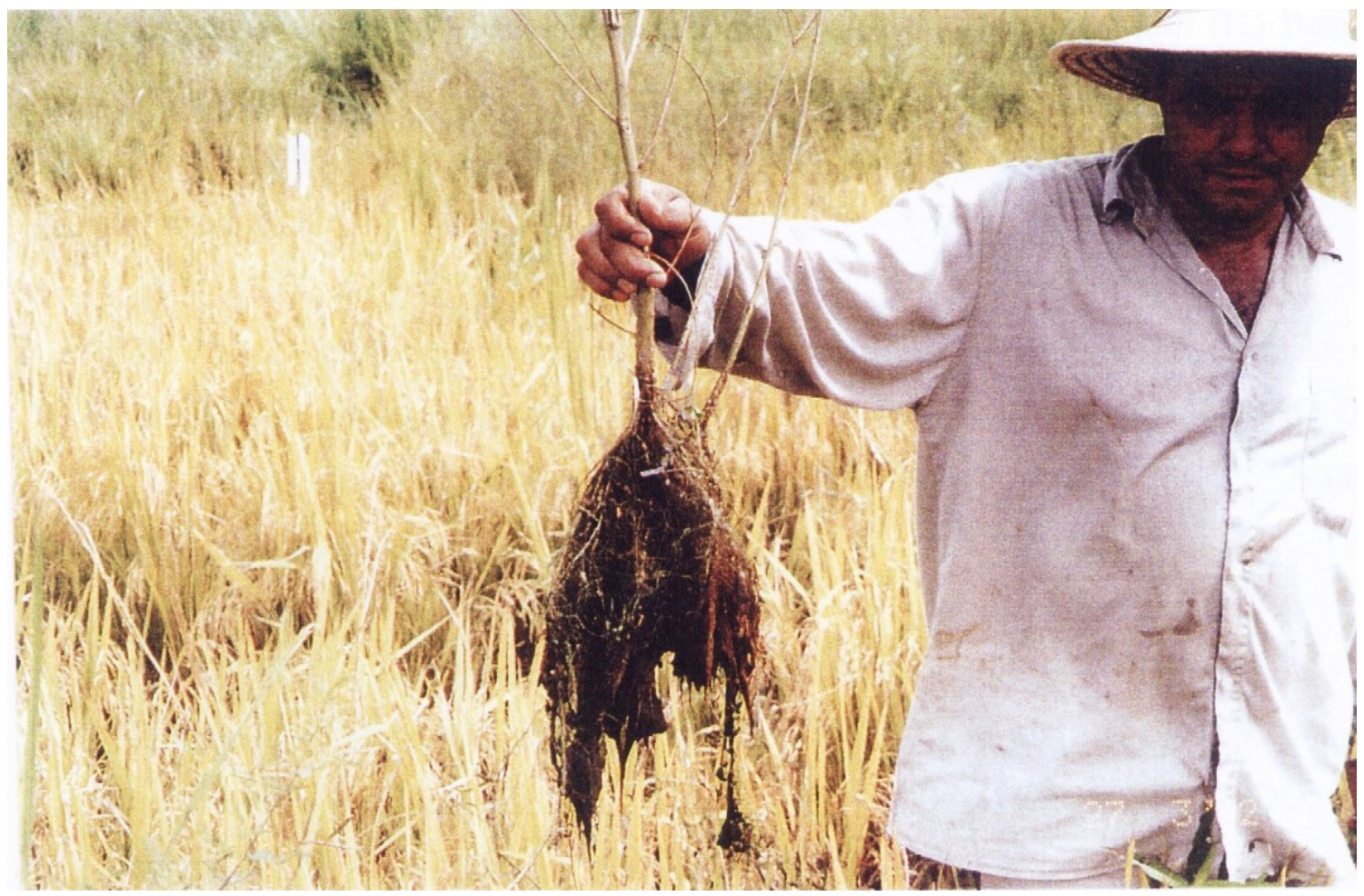

Anexo 20 - Sistema radicular de planta adulta de $A$. rudis. 


\section{REFERÊNCIAS BIBLIOGRÁFICAS}

ABUD, J.K. Comparativo de herbicidas em arroz irrigado. In: REUNIÃO DA CUlTURA DO ARROZ IRRIGADO, 14., Pelotas, 1985. Anais. Pelotas: EMBRAPA, CPAT, 1985. p.344-350.

ABUD, J.K. Controle químico de Echinochloa spp. e Aeschynomene sp. em arroz irrigado. In: REUNIÃO DA CULTURA DO ARROZ IRRIGADO, 19., Florianópolis, 1991a. Anais. Florianópolis: EMPASC, 1991. p.316-318.

ABUD, J.K. Efeitos de herbicidas no controle de Echinochloa crusgalli (L.) Beauv. Aeschynomene rudis Benth. em arroz irrigado. In: REUNIÃO DA CULTURA DO ARROZ IRRIGADO, 19., Florianópolis, 1991. Anais. Florianópolis: EMPASC, 1991b. p.285-289.

ABUD, J.K. Efeitos dos herbicidas fenoxaprop-ethyl e quinclorac no controle de Echinochloa crusgalli e Aeschynomene rudis em arroz irrigado. In: REUNIÃO DA CULTURA DO ARROZ IRRIGADO, 19., Florianópolis, 1991. Anais. Florianópolis: EMPASC, 1991c. p.297-299.

ABUD, J.K. Efeitos de diferentes doses de herbicida bensulfuron-metil comparado ao bentazon e 2,4 D éster no controle de Cyperus iria L. e Aeschynomene rudis Benth. Em arroz irrigado. In: REUNIÃO DA CULTURA DO ARROZ IRRIGADO, 20., Pelotas, 1993. Anais. Pelotas: EMBRAPA, CPAT, 1993. p.250-252. 
ADORYAN, M.L.; GELMINI, G.A.; DARIO, G.J.A. Uso do herbicida ethoxysulfuron no controle de Cyperus iria e Aeschynomene rudis em arroz irrigado. In: CONGRESSO BRASILEIRO DA CIÊNCIA DAS PLANTAS DANINHAS, 22., Foz do Iguaçu, 2000. Resumos. Foz do Iguaçu: SBCPD, 2000. p.205.

ANDRADE, V.A. Controle integrado do angiquinho (Aeschynomene spp) em arroz irrigado. In: REUNIÃO DA CULTURA DO ARROZ IRRIGADO, 15., Porto Alegre, 1986. Anais. Porto Alegre: EMBRAPA, CPAT, 1986. p.301-303.

ANDRADE, V.A. Controle de angiquinho (Aeschynomene spp) em arroz irrigado. In: REUNIÃO DA CULTURA DO ARROZ IRRIGADO, 16., Florianópolis, 1987. Anais. Florianópolis: EMPASC, 1987. p.259-261.

ANDRADE, V.A.; SILVA, O. S. Controle do angiquinho (Aeschynomene spp) em arroz irrigado. In: REUNIÃO DA CULTURA DO ARROZ IRRIGADO, 18., Porto Alegre, 1989. Anais. Porto Alegre: IRGA, 1989. p.522-525.

ANDRES, A.; MENEZES, V.G. Controle de capim arroz (Echinichloa crusgalli L. Beauv.) e angiquinho (Aeschynomene denticulata Benth.) com o herbicida bispyribac-sodium (Nominee) em arroz irrigado. In: REUNIÃO DA CULTURA DO ARROZ IRRIGADO, 22., Camboriu, 1997. Anais. Camboriu: IRGA, 1997. p.414418.

ARANHA, C.A.; PIO, R.M. Plantas invasoras da cultura do arroz (Orysa sativa L.) no Estado de São Paulo. Planta Daninha, v.4, p.33-57, 1981.

BALBINOT JUNIOR, A.A.; FLECK, N.G.; AGOSTINETO, D.; RIZZARDI, M.A.; MEROTTO JUNIOR, A.; VIDAL, R.A. Velocidade de emergência e crescimento inicial de cultivares de arroz irrigado influenciando a competitividade com as plantas daninhas. Planta Daninha, v.19, n.3, p.305-316, 2001. 
BIZZI, A.F.; ANDRES, A. Controle de Cyperus iria e Aeschynomene denticulata no sistema convencional de cultivo do arroz. In: REUNIÃO DA CULTURA DO ARROZ IRRIGADO, 24., Porto Alegre, 2001. Anais. Porto Alegre: IRGA, 2001. p.550-552.

CALEGARO, P.R.; BAUER, D. Plantas daninhas em arroz irrigado. Correio Agrícola Bayer, n.2, p.536-539, 1983.

CARVALHO, F.T. de; CAVAZZANA, M.A.; CESTARE, M.A. Eficácia de herbicidas no controle pré-emergente de plantas daninhas na cultura do arroz. Revista Brasileira de Herbicidas, v.1, n.3, p.213-217, 2000.

CHRISTOFFOLETI, P.J.; VICTÓRIA FILHO, R. Curso: biologia e manejo de plantas daninhas. Piracicaba: ESALQ, Departamento de Produção Vegetal, 2002. 38p. (Módulo 4: Competição e alelopatia).

COBUCCI, T. Plantas daninhas do arroz e seu controle. In: BRESEGHELLO, F.; STONE, L.F. (Ed.). Tecnologia para o arroz de terras altas. Santo Antonio de Goiás: Embrapa Arroz e Feijão, 1998. cap.11, p.80-110.

COBUCCI, T.; NOLDIN, J.A. Plantas daninhas e seu controle. In: VIEIRA, N.R.A.; SANTOS, A.B.; SANTANA, E.P. (Ed.). A cultura do arroz no Brasil. Santo Antônio de Goiás: EMBRAPA Arroz e Feijão, 1999. cap.13, p.375-415.

COLE, T.A.; WEHTJE, G.R.; WILCUT, J.W.; HICKS, T.V. Behavior of imazethapyr in soybeans (Glycine max), peanuts (Arachis hypogaea) and selected weeds. Weed Science, v.37, n.5, p.639-644, 1989. 
CONSTANTIN, J.; ZAGATTO, A.; CONTIERO, R.L. Eficiência do oxadiazon no controle de plantas daninhas na cultura do arroz irigado (Oryza sativa). Lavoura Arrozeira, v.48, n.424, p.3-7, 1995.

DARIO, G.J.A. Adubação corretiva e de manutenção e seus efeitos em um solo de cerrado e na produção e qualidade do arroz (Oryza sativa) Piracicaba, 1987. 91p. Dissertação (Mestrado) - Escola Superior de Agricultura “Luiz de Querioz”, Universidade de São Paulo.

DARIO, G.J.A. Informações básicas para o cultivo do arroz (Oryza sativa L.) nos sistemas de sequeiro e irrigado no Estado de São Paulo. Piracicaba: ESALQ, 1992. 14p.

DARIO, G.J.A.; ADORYAN, M.L Eficiência do herbicida Ethoxysulfuron no controle de plantas daninhas na cultura do arroz (Oryza sativa) irrigado. In: CONGRESSO BRASILEIRO DA CIÊNCIA DAS PLANTAS DANINHAS, 22., Foz do Iguaçu, 2000. Resumos. Foz do Iguaçu: SBCPD, 2000. p.209.

DARIO, G.J.A.; LAZARINI, E.; MATTOS, J.B.S. Controle de Aeschynomene rudis (angiquinho) na cultura do arroz irrigado com novo herbicida seletivo. In: CONGRESSO BRASILEIRO DA CIÊNCIA DAS PLANTAS DANINHAS, 20., Florianópolis, 1995. Resumos. Florianópolis: SBCPD, 1995. p.127.

DARIO, G.J.A.; MATTOS, J.B.S.; ADORYAN, M.L Avaliação do herbicida Ethoxysulfuron no controle de Aeschynomene rudis e Cyperus iria na cultura do arroz (Oryza sativa) irrigado. In: CONGRESSO BRASILEIRO DA CIÊNCIA DAS PLANTAS DANINHAS, 21., Caxambu, 1997. Resumos. Caxambu: SBCPD, 1997. p.155. 
De DATTA, S.K.; HERDT, R.W. Weed control technology in irrigated rice. In: INTERNATIONAL RICE RESEARCH INSTITUTE. Weed control in rice. Manila: IRRI; IWSS, 1983. cap.8. p.89-108

EBERHARDT, D.S.; ANDRES, A. Controle de Cyperus iria e Aeschynomene denticulata no sistema convencional de cultivo do arroz. In: REUNIÃO DA CULTURA DO ARROZ IRRIGADO, 22., Camboriú, 1997. Anais. Camboriú: EPAGRI, 1997. p.387-390.

EMPRESA BRASILEIRA DE PESQUISA AGROPECUÁRIA. Recomendações técnicas para a cultura do arroz irrigado: delineamento macroagroecologico; zonas 1, 23, 46, 47, 54, 71 e 87. Brasília,1992. 79p.

EMPRESA DE PESQUISA AGROPECUÁRIA E EXTENSÃO RURAL DE SANTA CATARINA. Arroz irrigado: recomendações técnicas da pesquisa para o sul do Brasil. 4.ed. Itajaí: EPAGRI, EMBRAPA, CPACT, IRGA, 1997. 80p.

FAGERIA, N.K. Maximizing crop yields. New York: Marcel Dekker, 1992. 274p.

FERNANDES, A. O Táxon Aeschynomene no Brasil. Fortaleza: EUFC, 1996. 128p.

FERREIRA, C.M.; YOKOYAMA, L.P. Cadeia produtiva do arroz na Região Centro-Oeste. Brasília : Embrapa Produção de Informação, 1999. 110p.

FISCHER, A.J.; RAMIREZ, A. Mixed weed infestations prediction of crop losses for economic weed management in rice. International Journal of pest Management, v.39, n.3, p.354-357, 1993.

FNP CONSULTORIA \& COMÉRCIO. Agrianual 2003: anuário da agricultura brasileira. São Paulo, 2003. p.219-228: Arroz. 
FORNASIERI FILHO, D., FORNASIERI, J.L. Manual da cultura do arroz. Jaboticabal: FUNEP, 1993. 221p.

GARRET, K.A. Select a sampling method for weed densities: the case of weed removal in strips. Weed Science, v.43, n.3, p.394-401, 1995.

GELMINI, G.A. Herbicidas: indicações básicas. Campinas: Coordenadoria de Assistência Técnica Integral, 1988. 334p.

GELMINI, G.A.; CHRISTOFFOLETI, P.J.; VICTORIA FILHO, R. Controle de Cyperus iria e Aeschynomene rudis em arroz com Ethoxysulfuron. In: CONGRESSO BRASILEIRO DA CIÊNCIA DAS PLANTAS DANINHAS, 21., Caxambu, 1997. Resumos. Caxambu: SBCPD, 1997. p.158.

GHOSHEH, H.Z.; HOLSHOUSER, D.L.; CHANDLER, J.M. Influence of density no johnsongrass (Sorghum halepense) interference in field corn (Zea mays). Weed Science, v.44, n.4, p.879-883, 1996.

GLIESSMAN, S.R. Agroecologia: processos ecológicos em agricultura sustentável. Porto Alegre: Editora UFRGS, 2001. 653p.

GUIMARÃES, E.P.; SANTANA, E.P. Sistemas de cultivo In: VIEIRA, N.R.A.; SANTOS, A.B.; SANTANA, E.P. (Ed.). A cultura do arroz no Brasil. Santo Antônio de Goiás: EMBRAPA Arroz e Feijão, 1999. cap.1, p.18-32.

HEAP, I.M. International survey of herbicide resistant weeds. http://www.weedscience.com (21 May, 2003).

INSTITUTO DE ECONOMIA AGRÍCOLA. Banco de dados do IEA. http//www.iea.sp.gov.br (22 maio 2003). 
KISSMANN, K.G.; GROTH, D. Plantas infestantes e nocivas. 2.ed. São Paulo: BASF, 1999. v.2, 978p.

KOCHER, H.; DICKERHOF, G. Mode of selective action of the herbicide Hoe 095404. In: BRIGHTON CROP PROTECTION CONFERENCE: WEEDS. Brighton, 1995 Proceedings. Farnham:BCPC, 1995. v.1. p.249-254.

KRUEGER, D.W.; WILKERSON, G.G., GOLD, H.J. An economic analysys of binomial sampling for weed scouting. Weed Science, v.48, n.1, p.53-60, 2000.

KWON, S.L.; SMITH, R.J.; TALBERT, R.E. Interference of red rice (Oryza sativa) densities in rice (O. sativa). Weed Science, v.39, n.2, p.169-174, 1991.

LORENZI, H. Manual de identificação e controle de plantas daninhas: plantio direto e convencional. 5.ed. Nova Odessa: Plantarum, 2000a. 362p.

LORENZI, H. Plantas daninhas do Brasil: terrestres, aquáticas, parasitas e tóxicas. 3.ed. Nova Odessa: Plantarum, 2000b. 608p.

MEDEIROS, R.D.. Efeitos do manejo de água e de sistemas de controle de plantas daninhas em arroz (Oryza sativa L.) Irrigado. Piracicaba, 1995. 80p. Dissertação (Mestrado) - Escola Superior de Agricultura “Luiz de Querioz”, Universidade de São Paulo.

MELLO, I. Plantio direto de arroz irrigado no sul do Brasil. Lavoura Arrozeira, v.48, n.422, p.3-8, 1995.

McGREGOR, J.T.; SMITH, R.J.; TALBERT, R.E. Interspecific and intraspecific interference of broadleaved signalgrass (Brachiaria platyphylla) in rice (Oryza sativa). Weed Science, v.36, n.5, p.589-593, 1988. 
MINISTÉRIO DA AGRICULTURA, PECUARIA E ABASTECIMENTO. Sistema de agrotóxicos fitossanitários. http://www.agricultura.gov.br/ (22 maio 2003).

NGOUAJIO, M.; McGIFFEN JUNIOR, M.E.; MANSFIELD, S.; OGBUCHIEKWE, E. Comparison of methods to estimate weed populations and their performance in yield loss description models. Weed Science, v.49, n.3, p.385-394, 2001.

NOLDIN, J.A. Controle químico de plantas daninhas, com solo inundado, em pósemergência em arroz irrigado. In: REUNIÃO DA CULTURA DO ARROZ IRRIGADO, 18., Porto Alegre, 1989. Anais. Porto Alegre: IRGA, 1989. p.537543.

NOLDIN, J.A. Eficácia e seletividade do herbicida 2,4-D, aplicado em diferentes doses, épocas e formulações em arroz irrigado Revista Brasileira de Herbicidas, v.2, n.3, p.107-112, 2001.

NOLDIN, J.A.; EBERHARDT, D.S.; RAMPELOTTI, F.T. Cyperus difformis L. Resistente a herbicidas inibidores da ALS em Santa Catarina In: CONGRESSO BRASILEIRO DA CIÊNCIA DAS PLANTAS DANINHAS, 23., Gramado, 2002. Resumos. Gramado: SBCPD, 2002. p.198.

ODUM, E.P. Ecologia. 2.ed. São Paulo: Pioneira, 1975. 234p.

ODUM, E.P. Ecologia. Rio de Janeiro: Guanabara, 1988. 434p.

OERKE, E.C.; DEHNE, H.W.; SCHÖNBECK, F.; WEBER, A. Crop production and crop protection: estimated losses in major food and cash crops. Amsterdam Elsevier, 1994. 808p. 
OLIVEIRA JUNIOR, R.S.; Introdução ao controle químico. In: OLIVEIRA JUNIOR, R.S.; CONSTANTIN, J. (Ed.). Plantas daninhas e seu manejo. Guaíba: Agropecuária, 2001. cap.6, p.187-206.

PEREIRA, U.J. O arroz no mundo. Lavoura Arrozeira, v.26, n.273, p.4-13, 1973.

PINZAN, N.R. Arroz (Oryza sativa L.). In: COORDENADORIA DE ASSISTÊNCIA TÉCNICA INTEGRAL. Manual técnico das culturas. 2.ed. Campinas, 1997. 1v: cereais, fibrosas, leguminosas, oleaginosas, plantas tropicais, raízes e tubérculos, sacarinas, p.103-156. (CATI. Manual,8)

RICKLEFS, R. The economy of nature. New York: VM Freeman, 1997. 677p.

RODRIGUES, B.N.; ALMEIDA, F.S. Guia de Herbicidas. 4. ed. Londrina, 1998.

SAARI, L.L.; COTTERMAN, J.C.; THILL, D.C. Resistance to acetolactate synthase inhibiting herbicides. In: POWLES, S.; HOLTUM, J.A.M. (Ed.). Herbicide resistance in plants: biology and biochemistry. Boca Raton: Lewis, 1994. p.83139.

SANTOS, F.J.; PITOMBEIRA, J.B.; PINHO, J.L.N.; MELO, F.I.O. Controle químico de plantas daninhas no Estado do Ceará. Planta Daninha, v.18, n.1, p.29-37, 2000.

SCHWANKE, A.M.L.; ANDRES, A.; PINTO, J.J.O.; FREITAS, G.D.; SANTOS, G.G.; CONCENÇO, G. Controle de capim arroz (Echinochloa crusgalli) e angiquinho (Aeschynomene denticulata) com o herbicida cyhalofop isolado ou em mistura com herbicidas pré-emergentes em arroz irrigado. In: REUNIÃO DA CUlTURA DO ARROZ IRRIGADO, 24., Porto Alegre, 2001. Anais. Porto Alegre: IRGA, 2001. p.554-557. 
SHAW, D.R.; RANKINS JUNIOR, A.; RUSCOE, J.T.; BYRD JUNIOR, J.D.. Field validation of weed control recommendations from herb and swc herbicide recommendation models. Weed Technology, v.12, n.1, p.78-87, 1998.

SMITH JUNIOR, R.J. Weeds of major economic importance in rice and yield losses due to weed competition. In: INTERNATIONAL RICE RESEARCH INSTITUTE. Weed control in rice. Manila: IRRI; IWSS, 1983. cap.2. p.19-36.

STAUBER, L.G.; SMITH JUNIOR, R.J.; TALBERT, R.E. Density and spatial interference of banyardgrass (Echinochloa crusgalli) with rice (Oryza sativa). Weed Science, v.39, n.2, p.163-168, 1991.

STIDHAM, M.A. Herbicides that Inhibit Acetohydroxyacid Synthase. Weed Science, v.39, p.428-434, 1991.

SWINTON, S.M.; BUHLER, D.D.; FORCELLA, F.; GUNSOLUS, J.L.; KING, R.P. Estimation of crop yield loss due to interference by multiple weed species. Weed Science, v.42, n.1, p.103-109, 1994.

TOZANI, R.; SILVA E.R. Interferência de Cyperus rotundus em arroz de sequeiro conduzido em três densidades e dois espaçamentos. Planta Daninha, v.13, n.2, p.87-97, 1995.

VANDEVENDER, K.W.; COSTELLO, T.A.; SMITH JUNIOR, R.J. Model of rice (Oryza sativa) yield reduction as a function of weed interference. Weed Science, v.45, n.2, p.218-224, 1997.

VAN GESSEL, M.J.; SCHWEIZER, E.E.; GARRET, K.A.; WESTRA, P. Influence of weed density and distribution on corn (Zea mays) yield. Weed Science, v.43, n.2, p.215-218, 1995. 
VICTÓRIA FILHO, R.; CHRISTOFFOLETI, P.J. Curso: biologia e manejo de plantas daninhas. Piracicaba: ESALQ, Departamento de Produção Vegetal, 2001. Módulo 1: Conceitos, histórico, danos e benefícios das plantas daninhas, 33p.

VIDAL, R.A.; MEROTO JUNIOR, A. Herbicidologia. Porto Alegre:R.A. Os autores, 2001. 152p.

XAVIER, F.E.; PINTO, J.J.O. Controle de Angiquinho (Aeschynomene hispida Willd.) com herbicidas aplicados em dois diferentes estágios do desenvolvimento do arroz irrigado In: REUNIÃO DA CULTURA DO ARROZ IRRIGADO, 12., Porto Alegre, 1983. Anais. Porto Alegre: IRGA, 1983. p.192-195.

XAVIER, F.E.; PINTO, J.J.O. Comportamento de herbicidas aplicados em duas épocas do desenvolvimento do arroz irrigado no controle de Aeschynomene spp. In: REUNiÃO DA CULTURA DO ARROZ IRRIGADO, 14., Pelotas, 1985. Anais. Pelotas: EMBRAPA, CPAT, 1985. p.351-355.

WILES, L.J.; WILKERSON, G.G.; GOLD, H.J.; COBLE, H.D. Modeling weed distribution for postemergence control decisions. Weed Science, v.40, n.4, p.546553, 1992. 